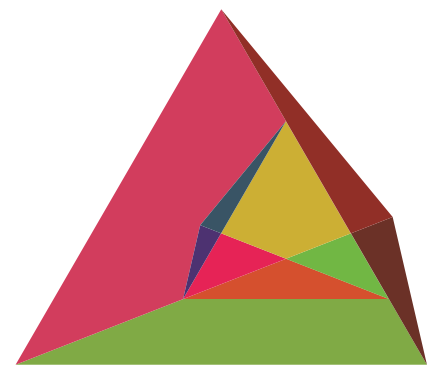


$89 \mathrm{p}$.

Dissertação (Mestrado - Mestrado em Artes) -Universidade de Brasília, 2016.

1. cinema de exposição. 2. ritual de morte. 3 . simulacro de morte. 4. videoinstalação. 5. descrição da paisagem. I. Camara, Rogério, orient. II. Título.

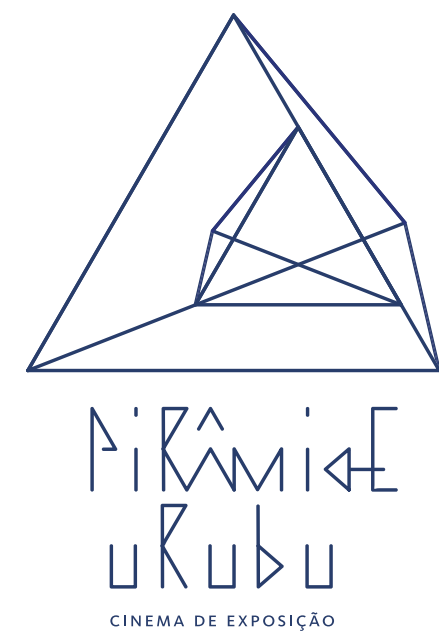




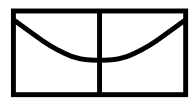

UNIVERSIDADE DE BRASÍLIA

INSTITUTO DE ARTES

PROGRAMA DE PÓS-GRADUAÇÃO EM ARTE

\section{PIRÂMIDE, URUBU - CINEMA DE EXPOSIÇÃO}

Maurício Chades

Dissertação apresentada ao Programa de Pós-Graduação em Arte (PPG-Arte/UnB) como requisito para conclusão do curso Mestrado em Artes, linha de pesquisa: Arte e Tecnologia.

Orientador | Dr. Rogério Camara

Brasília, julho de 2016 
a minha mãe, Lavina Chades, que me concede horizontes

a meu pai, Antônio Elias, pelas conversas noturnas

a Yasmin Adorno, por cerebrar e celebrar comigo todos os dias desde a inauguração do Espaço AVI, nosso ateliê, espaço para todas as flutuações

a Julian, Noa e Ofir, por experimentarem comigo um tipo de cinema adormecido na caverna Terra Ronca

a Rogério Câmara, orientador paciente a Christus Nóbrega, orientador durante a primeira parte do curso a Sônia Paiva, por me permitir percorrer o quintal de sua casa, o Parque de Produções a Yana Tamayo e Fátima Aparecida, membras da banca a Daniela Gonçalves, pela revisão cuidadosa e a Jackson Bagatoli, pelo abstract feito durante uma conexão no aeroporto

a Cícero Portella e Nayla Ramalho, pelas leituras atentas

a Gabriela Bílá, por me ajudar a espacializar o vídeo desenhando os croquis das videoinstalações

a Lucas Kato, João Quinto, Aluizio Alves, Diego Ferreira, Ana Maria Ultra, Flora Egécia, Janine Moraes, Rodrigo de Oliveira, Maurício Fonteles, Renato Perotto, Arnold Gules, Victor Lagden, Felipe Shuman, Marcos Antony, equipe de filmagens, companheiros nas horas

[literalmente] escuras no Urubu. 
"Eu vejo", videre, do latim, vídeo. Vídeo funciona como verbo de ação, ato mesmo de olhar. O vídeo está em todas as artes da imagem, pois todas pretendem, em comum, dar a ver. Está no desenho, na fotografia, na pintura, como o gesto de fazer imprimir o visível e o invisível. A escrita desta dissertação mistura-se e confunde-se com o próprio ato de fazer vídeos: os 6 vídeos e 6 ensaios aqui apresentados ora tocam-se, orbitando uma constelação de conceitos semelhantes, ora separam-se, abrindo-se para outras possibilidades e outros signos. O que torna o trabalho coeso, possível de ser organizado como série de vídeos e de textos, são 3 temas principais, formatados nas seguintes perguntas: a partir de experiências colhidas na biografia do artista, como é possível re-fazer, ritualizar a morte em um gesto-vídeo? Como o vídeo pode ser um estado de pensamento para que se proponham outros dispositivos-cinema? Como descrever a paisagem tornando-a outra, integrando e espacializando o vídeo?

vídeo. projeção. ritual de morte. simulacro de morte. descrição da paisagem. cinema de exposição. videoinstalação. 
"I see", videre, from latin, video. Video works as an action verb, the act of looking. Video is found within all image arts, as they all agree in the intent of giving sight. It's in drawing, photography, painting, as a gesture through which both visible and invisible are printed. The writing of this dissertation merges and confounds itself with the actual video making process: the 6 videos and 6 essay herein presented will, at times, touch one another, orbiting a constellation filled with similar concepts and, at times, separate from one another, opening up to accept distinct possibilities and other star signs. What makes this work cohesive, with the possibility of being organized as a series of video and text, is the presence of 3 main themes, formatted within the questions that follow: departing from experiences gathered in the biography of the artist, how is it possible to re-do, ritualize the death of a gesture-video? How can video be a state of thinking so that different device-cinema be proposed? How to describe landscape turning it into something else, integrating and spatializing video?

KEYWORDS

video. projection. death ritual. simulacrum of death. description of the landscape. exposition of cinema. video installation. 


\section{SUMÁRIO}

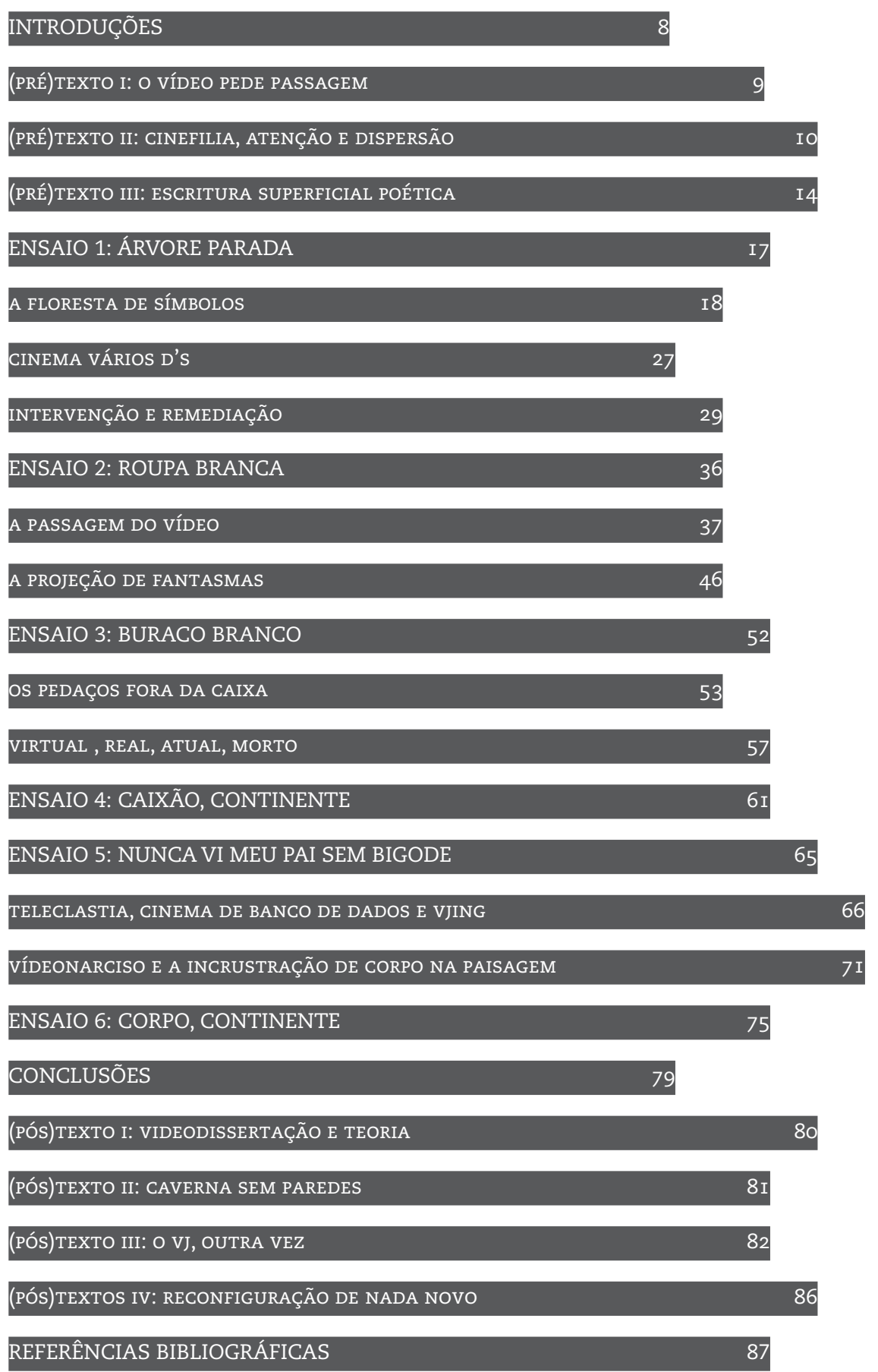


INTRODUÇÕES 
(PRÉ)TEXTO I:

O VÍDEO PEDE PASSAGEM

"Eu vejo", videre, do latim, vídeo. Vídeo funciona como verbo de ação, "ato mesmo de

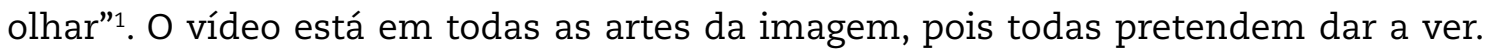
Está no desenho, na fotografia, na pintura, como o gesto de fazer imprimir o visível e o invisível. Revelar, evidenciar, antever. O vídeo está na impressão temporal da imagem, quando o espaço é subentendido. Videntes fazem vídeo.

Por estar nesse lugar de flutuações, é comum vê-lo disforme, sem identidade clara. Enquanto o cinema, uma versão mais estável do vídeo, claramente estabelece um espectro de possibilidades para chamar de seu, esse sequer precisa ser linguagem ou mídia, pode passar por aí também, mas várias das vezes em que se fala de vídeo nesta dissertação, estamos tratando de um estado de pensamento.

A falta de especificidade é uma das poucas características que podem ser designadas ao vídeo como sendo-lhe próprias. Ele está sempre presente como um adjetivo no trajeto de outras palavras e comumente é reduzido à ideia de suporte, quando ofusca-se toda sua potência de natureza mutável: o vídeo é um tempo e um espaço de onde vem e para onde pode-se enviar tudo, uma mudança que é a própria substância.

No português o vídeo disfarça-se ora de sufixo ora de prefixo, mas atualmente, desde as recentes reformas ortográficas, o "fixo" perde seu espaço resguardado e estável, quando não mais está protegido pelo hífen separador. A palavra vídeo encontra as palavras "performance" e "arte", por exemplo, e mistura-se a elas antes mesmo que se faça defesa da separação, antes que seja chamado de "registro" ou "documento". A palavra é pregnante e torna-se ela mesma a performance, a arte.

Como se escreve uma videodissertação? 


\section{(PRÉ)TEXTO II: \\ CINEFILIA, ATENÇÃO E DISPERSÃO}

Pirâmide, Urubu: Exposição de Cinema pode ser considerado um projeto transmidiático, uma vez que passa por várias mídias, que conseguimos reconhecer como filme, performance, videoinstalação; ou pós-midiático, quando seu aspecto "múltiplo" faz convergir todas essas linguagens, anteriormente reconhecíveis, em uma obra-evento cujas questões poéticas deslizam continuamente entre as superfícies de várias mídias, quando ações performáticas tornam-se filme, que então tornam-se videoinstalações e, também, o próprio texto em palavras escritas, a dissertação. Proponho, portanto, esta pesquisa em um campo de meios que refuta definições claras.

Já estive convicto de que o cinema seria meu ofício, até que outras possibilidades entre as artes visuais e o audiovisual passaram a ser centrais em minha produção, sem que nenhuma linguagem viesse a se tornar o único meio de expressão. Venho do frágil sonho da cinefilia e hoje percebo-me flutuando entre os espaços do cinema, das artes e da pista de dança: já não se trata de um momento de dúvida, mas de convicção pelo entrelugar. Tal escolha pode refletir em uma abertura às demandas que um projeto/ evento possam suscitar, quando, em muitos dos casos, ao longo do processo de um trabalho possam surgir partes em vídeo, em fotografia impressa, configurando-se aí uma série que se perde em seu próprio hibridismo, deixando de ser pintura e escultura, mas um múltiplo, uma arte do evento que, segundo Kátia Maciel, "não se trata apenas de seriar ou multiplicar os objetos, como nos processos industriais sempre discutidos pela arte, mas de multiplicar os acessos e resultados"2.

André Parente propõe o conceito "cinemático"3 para nomear os artistas que habitam ora o campo das artes visuais, ora o campo do cinema e, em um terceiro momento, causam indiscernibilidade entre ambos os campos, propondo um "cinema de artista". Ao nos falar dos artistas que expandem suas produções para o cinema e dos cineastas que fazem o caminho inverso, Parente recorre aquele termo "no sentido de demarcar a produção 'cinematográfica' de autores que circulam no circuito das artes visuais e que, portanto, são considerados artistas"4, ou seja, ele não está qualificando uma produção de cinema como arte e, em detrimento, desqualificando outra, já que "arte" não se refere a um adjetivo. Arlindo Machado também percebe esse fenômeno que marca uma geração de realizadores caracterizada por ele como "eclética": "gente que trabalha simultaneamente entre o cinema e a televisão, gente que produz indistintamente

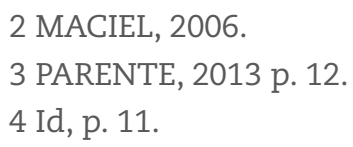


vídeos e filmes e ocupa todos os espaços do audiovisual”'.

Na sala escura, sentamos em uma poltrona para assistir as imagens passarem, enquanto os sons, ativados por caixas acústicas distribuídas ao redor das cadeiras, nos envolvem tridimensionalmente e nos prendem a atenção nesse estímulo único e concentrado, o filme. E se o cinema não tivesse poltronas? E se a tela fosse redonda? E se fossem várias telas? E se não houvesse imagem-movimento? E se os shoppings centers nos proporcionassem outros tipos de experiência instalativa para fruição de filmes que não fossem as tradicionais salas tão semelhantes em qualquer lugar do mundo?

O cinema continua forte na sua forma de espetáculo, mas é necessário fazer revisão dessa "Forma Cinema" com C maiúsculo, que não passa de pura idealização. Vivemos um universo de possibilidades estimuladas pela acessibilidade às tecnologias do audiovisual: seja na captura de imagens e edição, com câmeras digitais e computadores, os mais diversos, acessíveis a diversos preços; seja na "apresentação" das obras, em que os contextos de projeção também se manifestam mais diversificados, desde os vários festivais de cinema, vídeo experimental, videoarte, até as festas de música eletrônica em que predominam cada vez mais instalações audiovisuais imersivas e projeções live criadas pelos VJs; e, por fim, aos preços acessíveis de projetores de alta resolução que podem tornar tela as superfícies mais diversas, em espaços urbanos ou rurais. O Cinema de Exposição, portanto, é um fenômeno que pode ser comparado ao da pintura que deslocou-se da moldura ao longo do século 20: "o cinema sai da tela e coloca o espectador em movimento" ${ }^{\text {, }}$ seja deslocando-se a pé, na sala da galeria, ou mesmo dançando na pista de uma boate.

Os VJs parecem retornar à questão essencial dos "primeiros cinemas", quando a captura e a projeção tinham importâncias semelhantes:

Era comum que os planos de um filme viessem em rolos separados: o exibidor comprava quantos rolos quisesse e montava seu filme na ordem que bem entendesse. $O$ modo de projeção também não estava definido, uma vez que cada exibidor podia inventar o seu próprio "cinema", projetando por detrás da tela (back projection), em telas paralelas ou fundindo duas ou mais imagens simultâneas na mesma tela (efeito de fusão decidido pelo projecionista e não pelo produtor) ${ }^{7}$.

Em um primeiro momento, o trabalho do VJ consiste em "quebrar a tela": projeta-se em alguma superfície que provavelmente não tem a função de ser uma tela, desde a fachada de um prédio à copa das árvores. Ou seja, as imagens projetadas não sofrem um "emolduramento" como acontece na sala de cinema e até mesmo com as imagens

5 MACHADO, 2011, p. 188.

6 MACHADO; MACIEL, 2008, p. 75.

7 Id, p. 67. 
na televisão. A tela de aspecto 2,35:18 não existe mais, o som é música (uma proposta do DJ) e o espectador, livre da cadeira, finalmente pode dançar, se optar por isso. A partir do momento em que uma superfície deslocada recebe a projeção, o VJ mixa trechos curtos de vídeos, os loops, afim de criar imagens novas. Os loops podem ser tanto material criado pelo VJ quanto vídeos de outros artistas, desde trechos de videoclipes, de filmes a animações de efeito puramente sinérgico ou mesmo imagens produzidas no computador através de algorítimos. Sobreimpressões, recortes e mudanças nas qualidades das imagens (cor, contrate, saturação) são alguns dos diversos tipos de efeitos que o VJ pode lançar sobre as imagens, em uma eterna busca de projetar como principal ação: projeta-se primeiro para, em seguida, criar imagens.

É possível estabelecer relações entre a pista de dança e o Cinema Expandido, termo popularmente difundido por Gene Youngblood. Neste cinema, happenings e performances utilizavam projeções artísticas em um estreitamento de vídeos e corpos:

O cinema expandido é uma tentativa de criar um processo de participação do espectador. Tudo se passa como se o espetáculo do cinema desse um movimento ao corpo do espectador, liberando-o da cadeira, como ocorria com os shows de rock, as raves etc. Trata-se de um cinema com funções comportamentais, que procurava intensificar os efeitos perceptivos visuais e sonoros sobre o corpo do espectador?.

A desatenção passa a ser tratada como um problema sério ao longo dos séculos XIX e XX, ganhando várias classificações patológicas dentro da psiquiatria e psicologia, quando não se percebe que o próprio contexto de novas formas de produção industrial em larga escala inauguram e investem em mudanças psíquicas na percepção do indíduo urbano. Para George Simmel, "seria possível dizer que um aspecto crucial da modernidade é uma crise contínua da atenção, na qual as configurações variáveis do capitalismo impulsionam a atenção e a distração a novos limites e limiares" ${ }^{10}$, quando introduz novas fontes de estímulo e informação e, em seguida, insere novos métodos para administrar e regular a percepção.

Enquanto as experiências contemplativas na arte sugerem a sublimação do espaço ao redor para que protagonize a obra de arte, as novas tecnologias inscrevem suas contribuições reconfigurando a ideia de presença e atenção. Para acessarmos um trabalho de web-arte, por exemplo, precisamos estar presentes nos circuitos da rede. Assim, a ideia da virtualidade nunca expulsou a presença, apenas transformou e potencializou seus efeitos por meio da ubiquidade dos sistemas hídridos da comunicação ${ }^{11}$.

8 "2,35:1" trata de uma proporção de quadro muito tradicional no cinema. Lê-se: para cada 2,35 metros de largura, 1 metro de altura.

9 PARENTE; MACIEL, 2008, p. 38.

10 SIMMEL; VELHO, 1973. p 36.

11 MACIEL, 2006. Link acessado em julho de 2016: http://goo.gl/asToRW 
Nesse sentido, Jonathan Crary supõe que em meados do século XIX a percepção passa por mudanças, se caracterizando, sobretudo, "por experiências de fragmentação, choque e dispersão" ${ }^{12}$. Enquanto refuta-se a ideia de que as formas de leitura, atenção e concentração se metamorfoseiam com os vários estímulos provocados pelas novas formas de se viver nas cidades modernas, cada vez mais urbanas e polifônicas, a arte passa a absorver essas potencialidades em que a visão é apenas uma das camadas de um corpo que pode ser capturado, modelado ou controlado por uma série de estímulos externos. A presença se intensifica enquanto força propulsora de trabalhos que acontecem por meio do diálogo, de uma aproximação e interferência na obra causada pelo espectador. Assim, a presença, refigurada, é "móvel"13. A mobilidade é apropriada pela arte de hoje a partir do fluxo dos circuitos comunicacionais e a inclusão dos deslocamentos motores e sensoriais do corpo. O que significa que por um lado, as alterações nos padrões de comunicação que se popularizaram nos anos 80 , com a adoção do computador em rede, permitiram o fluxo de dados como nunca antes sonhado e, por outro lado, o corpo passa a ser pensado como um elemento que é parte do sistema.

O que torna o cinema essencialmente diferente de outras experiências do vídeo é, justamente, estar refém de um modelo de consumo. Sua forma rígida e ritualística fecha-se para diversas possibilidades, ao mesmo tempo que preserva sua longevidade. Mario Perniola nos lembra que "os ritos, as cerimônias, as instituições não constituem em absoluto um obstáculo às manifestações e ao crescimento da vida, mas, bem ao contrário, são uma condição de sua existência"14. Os momentos de ruptura, segundo o autor, também fariam parte de um acontecimento ritual ao redirecionarem o trajeto das tradições, de forma que talvez a seguinte questão pode ser colocada: seria o próprio vídeo um espaço para invenção de produções mais tradicionais como o cinema em um jogo constante de ativar e desativar potenciais?

Pensar um projeto desdobrando-o às múltiplas formas parece-me ser uma boa forma de conduzir a pesquisa integrando práticas diversas, desde a escrita ao Vjing. Pretendo participar dessa realidade pós-midiática que marca o nosso tempo, quando as obras já não se restringem aos modos tradicionais de se fazer, pois "elas são maiores que os meios, elas os atravessam e os ultrapassam. Em alguns casos, elas criam os seus próprios meios e suportes"15.

12 CRARY, 2013, p. 25.

13 MACIEL, 2006.

14 PERNIOLA, 2000, p. 34.

15 MACHADO; MACIEL, 2008, p. 71 
(PRÉ)TEXTO III:

ESCRITURA SUPERFICIAL POÉTICA

A intuição é uma via de acesso à precisão. "Não é um sentimento nem uma inspiração, uma simpatia confusa, mas um método elaborado, e mesmo um dos mais elaborados métodos da filosofia"16. Perceber o caminhar de minha pesquisa relacionar-se com o bergsonismo deu-se em uma etapa posterior, quando já realizava textos e vídeos e só depois reconheci semelhanças no modus de fazê-los com as propostas estabelecidas por Bergson, lidos aqui à luz de Deleuze. Quando sentia-me, a princípio, agindo "intuitivamente" diante do trabalho, não cogitava aproximar "intuição" da palavra método. Agia romântico, fugindo das delimitações, das possíveis ameaças dogmáticas a um projeto essencialmente pessoal, até perceber que a intuição, em Bergson, é um método que coloca a experiência de viver como central, ao mesmo tempo em que delimita as etapas de criação, não fugindo à ideia de método, uma forma organizada de colher e produzir conhecimento sensível.

Bergson separa em uma espécie de três atos "os quais determinam as regras do método"17: a primeira regra trata da criação de problemas; a segunda, à descoberta de verdadeiras diferenças de natureza; a terceira, à apreensão do tempo real. O que move esta pesquisa são impulsos cada vez mais claros à medida que são exercitados, e talvez seja esse o aspecto que me coloca em maior identificação com o bergsonismo, pois "trata-se de um método essencialmente problematizante"18, quando a primeira regra torna-se condição essencial para o desenrolar das próximas duas etapas. Os falsos problemas precisam cair para que sejam inventados e percebidos os verdadeiros, para então serem diferenciados e intersectados (segunda regra) e pensados em termos de duração (terceira regras). Dessa forma, ao filmar escrevendo, sem ainda perceber um recorte preciso no que pesquisava, faço uso do Bergsonismo atendo-me principalmente à primeira regra, em um repetitivo esforço de descobrir, criar e revelar problemas à medida que organizo o trabalho na seguinte estrutura: "Introduções"; 6 textos escritos em tom ensaístico; 6 ações videográficas intersectando, causando e sendo causadas pelos ensaios; e "Conclusões".

Encontrar os problemas e colocá-los aqui tornou-se o principal exercício da pesquisa. Primeiro surge a necessidade, a angústia movedora, que possibilita o ato de filmar ações performáticas, de residir uma casa nova ${ }^{19}$, pesquisar e escrever, relatar pensan-

16 DELEUZE, 2012, p. 9.

17 Id, p. 10.

18 Id, p. 29.

19 Tema debatido em Ensaio 1: Árvore Parada. 
do, "mais ainda do que resolvê-los" (os problemas):

Com efeito, um problema especulativo é resolvido desde que bem colocado. Ao dizer isso, entendo que sua solução existe nesse caso imediatamente, embora ela possa permanecer oculta e, por assim dizer, encoberta: só falta descobri-la. Mas colocar o problema incide sobre o que já existe, atualmente ou virtualmente; portanto, cedo ou tarde ela seguramente vem. (...) Colocação e solução do problema estão quase se equivalendo aqui: os verdadeiros grandes problemas são colocados apenas quando resolvidos ${ }^{20}$.

A escrita ensaística me parece uma escolha de estilo bastante conveniente para a forma com que os problemas são colocados na pesquisa, como uma grande busca, para além de uma conquista de resultados. Ações performáticas foram elaboradas para serem filmadas e algumas delas resultam em versões de videoinstalação, em uma relação de filmar-escrevendo e de escrever-editando. O tom de relato, de diário, de escritura poética, presente ao longo da dissertação, tornou-se instantâneo quando o processo fez perceber nos eventos cotidianos, banais e biográficos os elementos necessários para encenar ações reais como sendo mitológicas, filmadas e pensadas como vídeo.

O método de pesquisa possibilita que escritura e filmagens sejam um fazer enquanto trajetória: os 6 vídeos/ 6 ensaios ora tocam-se, orbitando uma constelação de conceitos semelhantes, ora separam-se, abrindo-se para outras possibilidades, signos e conceitos diferentes. O que torna o trabalho coeso, possível de ser organizado como série de vídeos e compilação de textos, são 3 temas principais, formatados nas seguintes perguntas: a partir de experiências colhidas na biografia do artista, como é possível re-fazer, ritualizar a morte em um gesto-vídeo? Como o vídeo pode ser um estado de pensamento para que se proponham outros dispositivos-cinema? Como descrever a paisagem tornando-a outra, integrando e espacializando o vídeo?

Os 6 vídeos e ensaios debatem, cada um, as três questões, nunca ao mesmo tempo, mas em uma alternância de importâncias: quando uma parece ser principal, logo é tirada do centro para que outra seja melhor debatida. Árvore Parada, Roupa Branca, Buraco Branco, 'Caixão, Continente', Nunca vi meu pai sem bigode e 'Corpo, Continente'21, quando textos ensaísticos, debatem: conceitos como "rito sem mito", "ritual de morte", simulacro de morte", à luz do filósofo italiano Mário Perniola; o vídeo, enquanto estado sensível de pensamento, é debatido a partir de Phillipe Dubois, Gilles Deleuze, André Parente, Gabriel Menotti, Arlindo Machado, Katia Maciel e Raymond Bellour; formas de olhar, perceber e produzir imagens a partir de uma vivência cotidiana, na paisagem, tratam de um aprendizado com Gaston Bachelard, Maurice Merleau-Ponty 
e Anne Cauquelin. Além de outros autores, diversos, colaboradores fragmentados das questões que abrem-se ao longo do percurso em sentidos imprevistos.

Ademais dos três temas principais, o trabalho aponta para um outro desdobramento, uma condição pós-midiática. Questionando o dispositivo cinema em sua forma única de consumo atual, o multiplex, faço uso do vídeo para explorar o máximo de suas possibilidades, recombinando-o à exaustão ao apresentar o trabalho em versões diferentes, inesgotáveis enquanto reinvenções. As ações videográficas têm versões como: videoarte, quando o tempo da ação protagoniza em vídeo monocanal; videoinstalação, quando são espacializadas e instaladas, produzindo aí uma outra imagem para além do que está filmado; curta-metragem, quando o material dos 6 vídeos é organizado em nova edição, como uma obra única a ser apresentada como "cinema", um filme a ser distribuído em festivais e mostras; e a última versão faz do material dos 6 vídeos uma biblioteca de loops para download gratuito na internet, a serem remixados em projeções por um VJ, na pista de dança. Assim, entre os vários possíveis deslocamentos do vídeo, tentarei conduzir o trabalho em um trajeto entre os espaços da galeria de arte, da sala de cinema e da pista de dança.

Afim de reforçar as trocas entre o que se filma e o que se escreve, indico no início de cada ensaio o link para acessar o vídeo homônimo, considerando importante o ato de assistir-lendo. Além disso, também componho nas páginas impressas da dissertação os quadros dos vídeos, desdobráveis na superfície do papel, e relaciono as imagens produzidas aqui com as obras de outros artistas e cineastas, justapostos no diálogo da pesquisa. Dessa forma, faço defesa de um pensamento artístico que possa articular o discurso texto-verbal ao mesmo tempo em que se coloca o texto-imagético, "e assim conduzir a imagem para um campo superior ao da mera figuração ilustrativa. A imagem pode e deve ser encarada como discurso, como argumento, como teoria" ${ }^{22}$. De forma que a dissertação não se apresenta como um relatório de criação e documentação de obras artísticas, mas como um texto que produz e é produzido por vídeos, que se infiltra no espaço e no tempo do vídeo para pensar com ele. 
Mudei-me de casa, deixei a Asa Norte, bairro de Brasília, para morar no Morro do Urubu, um núcleo rural a poucos quilômetros da cidade. Os contrastes evidentes entre os dois espaços foram incorporados neste trabalho, quando a série de vídeos realizados ganhou cenários para habitar e percorrer.

O Urubu têm um dos acessos possíveis pelo Lago Norte, local facilmente identificável se tomarmos como referência a Torre de TV Digital, visível de quase todo Distrito Federal: o território do Plano Piloto, marcado pela horizontalidade, tem o Urubu, um morro, como um hiato na paisagem, sendo o local de maior altitude do DF. Além de oferecer a tranquilidade das folhas, a presença de árvores e de uma cachoeira, de lá podemos ver a cidade do alto.

Projetada para carros, Brasília possui vias expressas onde acelera-se a velocidades altas, e o trajeto é poucas vezes interrompido por semáforos. Acessar o Portal das Águas ${ }^{24}$, para entrar no Urubu, exige que as pessoas, em seus carros velozes, repensem a pressa ao se colocarem na estrada de chão e apreendam novas formas de perceber as distâncias. Um quilômetro de estrada de chão é maior que um quilômetro de asfalto.

Residir no Urubu é aceitar as ofertas que o novo espaço traz ao trabalho. "O campo oferece tudo que a cidade subtrai - a calma, a abundância, o frescor e ócio para meditar" 25 , aceitando tais ofertas, "morar" incorporou-se ao meu trabalho e minha casa tornou-se também meu ateliê, um espaço para estar a maior parte dos dias. Para morar no trabalho.

Habito o território rural, mas não fujo da cidade. O Plano Piloto está logo alí, consigo ver do quintal e à noite o degradê das luzes dos postes marcar o céu, desde um tom mais vermelho até um mais preto. É um lugar para se estar para decantar os índices da cidade e recombiná-los, desde a luz elétrica às demarcações de terra, evidentes pelas cercas de arame farpado. Enquanto a cidade extrai uma quantidade diferen- 
te de consciência da que a vida rural extrai, quando "o ritmo da vida e do conjunto sensorial de imagens mentais flui mais lentamente, de modo mais habitual e mais uniforme"26 é que consigo propor uma suspensão sobre as dinâmicas de imagens que se tensionam em uma paisagem híbrida, entre árvores do cerrado no primeiro plano e a cidade mais distante, um microcosmo acessado justamente porque consigo já me desprender, pairar fora do tempo.

Boa parte do tempo em casa, estou só, outra oferta feita pelo espaço rural. Já não sou visitável com facilidade como quando vivia na Asa Norte e meus amigos batiam na minha porta quando ela estava no caminho. Bachelard alude à imagem da concha como signo de estar só. "Sabemos bem que é preciso estar só para habitar uma concha”"27, que ao viver a imagem, aceita-se a solidão. O caramujo modela sua casa com seu corpo e para ele. Suas escadas apenas são possíveis ao longo do tempo com o movimento feito pelo caramujo de sair para o mundo e retornar para o interior da casa, a concha. A casa de quem vive só pode ser modelada pelo uso que se faz dela.

O espaço novo tornou-se estimulante. O Urubu dava-se a ver o tempo todo, um estímulo que já não vivia no Plano Piloto, onde precisaria de um esforço maior para perceber suas ofertas e possibilidades, já pouco visíveis pelo olhar rotineiro, viciado. Percorri o Urubu em saídas fotográficas, em busca de cenários para vídeos, em uma tentativa de tornar o morro visível. O Urubu tornou-se um lugar para se pensar o que é o mundo, um território desconhecido a ser percorrido. "A arte faz perceber de que modo o visível se apresenta a nós"28, um meio privilegiado, portanto, para pensar e falar do mundo. Inserindo o Urubu nas obras, ele se torna visível.

O exercício de perceber e ver o novo espaço tinha como principal meta a condição de reconfigurar o visível, começar de um ponto zero de referência, descrever de olhos fechados, olhando para o escuro. Olhar adiante, fixar a câmera, escolher a lente e fechar o quadro - tornar quadro. "Não são os dados mundanos"29, nos reporta Anne Cauquelin, e sim os diversos modos de relação entre um dentro (os modos invisíveis da percepção) e um fora (a exposição e incorporação desses modos), que darão a perceber as imagens possíveis da paisagem.

O espaço que se apresentava parecia confuso e pouco domesticável pelo enquadramento. Para quem conhece a natureza por suas representações, seja na pintura ou no vídeo, enquanto imagens artificiais, não imagina com facilidade que a Natureza está criada em nosso imaginário através de uma série de quadros impostos diante da 
confusão das coisas, dos espaços de onde elas foram ou poderiam ter sido buscadas. Os quadros organizam a diversidade de matérias oferecidas pelo espaço e, "quando pensávamos nos banhar na verdade do mundo tal qual ele se nos apresentava, não fazíamos nada além de reproduzir esquemas mentais" ${ }^{30}$, herdando uma série de projeções anteriores. Quando somos apresentados à natureza, já não temos muitas chances de conhecê-la. Ao pintar-se um quadro, uma representação da paisagem, é possível acessar uma série de códigos de forma que o pintor não precisa dispor-se a ver, a representar, apenas reproduzir. O mundo reduziu-se aos limites das molduras, criados por gerações de olhares, e foi pintado com o auxílio de formas e de cores retirados do nosso arsenal cultural:

O fato de esse arsenal ser levemente diferente para outros indivíduos ou outros grupos não contradizia o fato mesmo da construção do visível. A natureza permanecia bastante "visível" sob a forma de um quadro. Com seus limites (a moldura), seus elementos necessários (formas de objetos coloridos) e sua sintaxe (simetrias e associações de elementos) ${ }^{31}$.

Percorrer o espaço carregando tripé e câmera já é uma primeira intenção que pode possibilitar o surgimento da paisagem. Vivenciando o espaço e olhando para ele, será possível reconhecer os elementos e os objetos que o compõe. As cercas de arame farpado no Urubu, as árvore nativas do Cerrado, a presença do som da cachoeira, as lâmpadas acesas nas varandas são alguns dos elementos que, se reconhecidos, um a um, revelarão a paisagem em um gesto de perceber. Os elementos, de inesgotável riqueza, são colocados no quadro, lugar privilegiado, "para aparecerem na harmonia emoldurada de uma forma, e incitariam então o interesse por todos os aspectos da Natureza, como por uma realidade à qual o quadro daria acesso"32.

É mais comum relacionar "quadro" ao objeto da pintura, delimitado pela moldura, mas também utilizamos com frequência a mesma palavra como sinônimo de "plano", conceito importado do cinema tradicional que, de forma semelhante à pintura, refere-se à organização visual-espacial de uma imagem, mas acrescenta um novo elemento de ordem técnica, a "duração": um plano tem a duração delimitada entre cortes, começando quando outro termina e acabando com o início do próximo plano. Arlindo Machado considera que o conceito de "plano" revela-se cada vez mais inadequado para descrever o processo organizado das imagens ${ }^{33}$, pois, em geral, há sempre infinidades de "planos" dentro de cada tela, encavalados, superpostos, recortados uns dentro dos outros. É como perceber as infinidades de paisagens que poderiam dar-se a ver, não fosse o recorte escolhido pelo artista. As paisagens, portanto, estariam sempre migrando de um 
meio a outro, ou dentro de um mesmo meio, do vídeo ao vídeo, de uma natureza a outra, pictórica, fotoquímica, eletrônica, digital, figuras em trânsito permanente.

Também vale importar outros dois conceitos do cinema tradicional: o campo e o extra-campo. O campo é o espaço revelado no interior do quadro, ou seja, trata-se da imagem delimitada pelas bordas do enquadramento. O extra-campo é tudo o que não está contemplado nos limites do quadro, o lado de fora da imagem. É comum no cinema, por exemplo, perceber o som espalhando-se para além dos limites do quadro, quando ouvimos o ambiente ou quando ouvimos o assobio de uma árvore caindo fora da imagem. O extra-campo é um espaço que se infere, é tudo que a imagem (paisagem) também pode ser.

Como proposta de primeira prática artística morando no Urubu, decidi realizar um vídeo em que descrevo o que é invisível na paisagem e tomo como ponto de partida o quintal do Parque de Produções Sônia Paiva. Os limites do quintal, marcados pela cerca de arame, apontam para um horizonte de onde se vê toda a cidade, no que resulta uma videoinstalação site-specific ${ }^{34}$, um circuito que começa com as filmagens e passa pelo mapeamento da cerca para que receba projeções.

Estendendo um tecido sobre a cerca, pretendo apagá-la, reintegrando os espaços de dentro, o jardim do Parque, e o de fora, uma paisagem a ser revelada ao longo da videoinstalação. $O$ entusiamo com o videomapping ${ }^{35}$, uma tecnologia relativamente recente, gerou uma série de propostas de artistas que tentaram aderir vídeo e espaço com um máximo de realismo. Edifícios foram destruídos com projeções, monstros pularam de um arranha-céu a outro em grandes metrópoles, dentre vários outros exemplos em que o videomapping foi utilizado para criar intervenções no espaço urbano.

\footnotetext{
34 O termo site-specific designa uma série de trabalhos artísticos que questionam o espaço estéril e idealista puro da galeria de arte. Em um primeiro momento, artistas como Hans Haacke e Robert Smithson deslocaram-se para a materialidade da paisagem natural ou para o espaço impuro e ordinário do cotidiano, fazendo dos componentes ambientais como centrais no trabalho. Escala, tamanho, localização e leis da física, como a gravidade, implicam um "enraizamento" da obra ao espaço. "Os trabalhos tornam-se parte do lugar e reestruturam sua organização tanto conceitual quanto perceptualmente" (KOWN, 1997, p.168).

35 Fernando Rabelo, curador do projeto Reconvexo Itinerante, que trata de selecionar e expor obras que utilizam a projeção mapeada sobre pequenos objetos, ou seja, deslocada do contexto monumental das projeções em prédios, considera que o surgimento da técnica de mapeamento digital das superfícies de projeção, a tridimensionalização do espaço de projeção, faz com que o conteúdo exibido não necessite mais da superfície plana e retangular. Essa tecnologia libertou, portanto, as imagens projetas e proporcionou que todos os objetos opacos ou translúcidos sejam uma superfície ideal para projeção. "A partir dessas experimentações, prédios, casas, fachadas históricas, estátuas, praças, ou seja, qualquer objeto pode receber a luz do projetor, ser mapeado, e se tornar projetável" (RABELO, 2015, p. 13).
} 


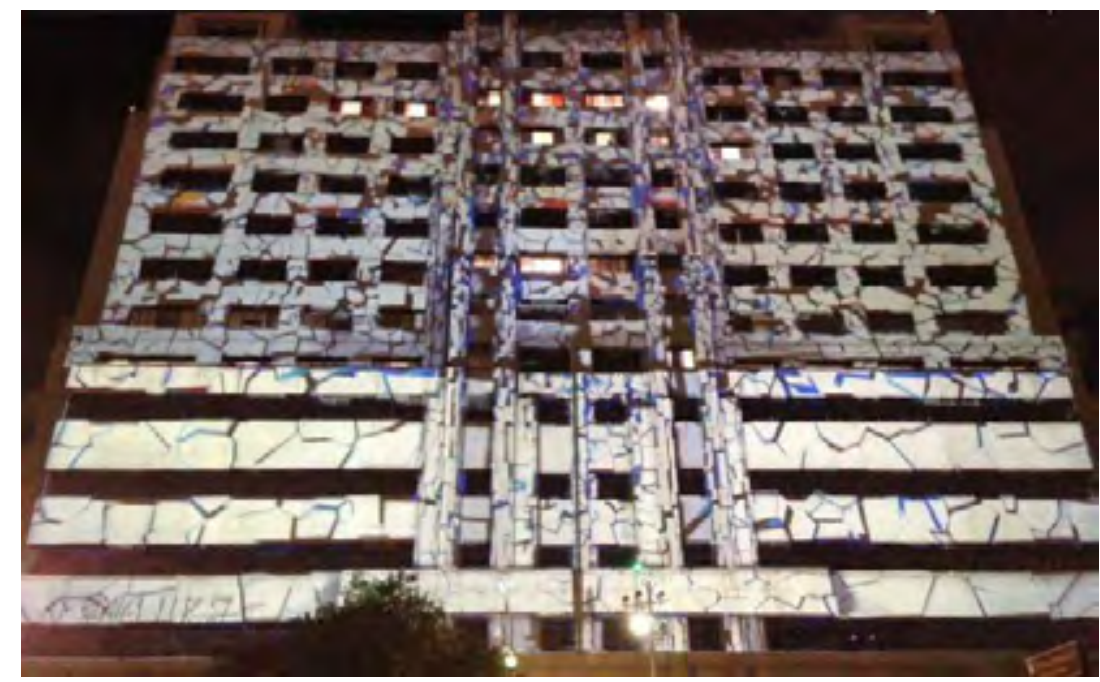

Durante a Virada Cultural de São Paulo 2014, grupos de VJs projetaram no antigo prédio Mappin, no centro da cidade (foto: Angelo Dias/Folhapress)

Em Árvore Parada não pretendo um realismo perceptivo de escala humanista, no sentido de causar uma indiscernibilidade entre o que é a cerca com imagens projetadas e o que é o fundo, o lado de fora. A colagem aqui proposta pede que o fruidor interaja, percebendo a intervenção na paisagem, deslocando-se em torno da obra, um vídeo que só acontece quando percebido projetado, instalado, quando o fruidor "vê" a (in) discernibilidade, o que une e o que separa o contexto da invisibilidade filmada e, agora, projetada. Árvore Parada só ganha forma quando em composição, re-colocada no contexto (o Urubu).

O trabalho pretende tornar a paisagem possível através do enquadramento, "pelo qual subtraímos ao olhar uma parte da visão"36 - "isso entra", "isso não entra", em uma busca pela harmonia dos elementos naturais, por uma unidade colocada no quadro. A condição que se coloca é a de que a janela e a moldura são "passagens" para ver a paisagem ali onde, sem elas haveria apenas a natureza. Para descrever o espaço com minúcia, como se nele houvesse moléculas de mundo, um minimundo, "para enclausurar todo um espetáculo numa molécula de desenho" ${ }^{37}$, é preciso amar. Amar como possibilidade de vivenciar, de direcionar energia, de fazer fluir um desejo de percorrer o espaço e nele ver imensidão.

A colagem que se faz ao projetar planos, enquadramentos, de pedaços do Urubu espalhados pela Natureza, não é uma colagem que faça o público apertar os olhos, perdendo-se entre objeto e fundo, entre obra, escultura, e contexto. Mesmo não pretendendo problematizar como "é pintura ou fotografia?" o que se coloca com o vídeo é um ob- 
jetivismo subjetivo, para substituir a descrição visual pelo objeto real, uma imagem que seja indiscernível "no interior" de quem olha para ela. "Tanto de um lado quanto de outro, a descrição tende para um ponto de indiscernibilidade do real e do imaginário"38. Não se pretende descrever um fim, de forma que as árvores projetadas na tela "colem" com as árvores atrás dela, as "verdadeiras". O imaginário, o espaço de quem vê, onde a obra continua, é composto de milhares de dobras, "de milhares e milhares de memórias, e, se possível que elas se tenham constituído porque eram convocadas pelo 'fundo',"39 nós, contudo, não teríamos por testemunho nada além da multiplicidade dessas mesmas formas, suas variações.

A paisagem descrita é uma imagem ofertada para o imaginário, uma transmissão de olhares, que deverá emendar-se com o que já está lá: os relatos orais, um trecho de um filme, os desenhos das nuvens, as margens tranquilas do córrego. A natureza como paisagem se dá pelo olhar dos outros, quando um doador faz com um gesto, de escrita, fotografia, pintura, um desvelamento e inaugura aquilo que por muito tempo será considerado para nós o "real".

Parece ser uma grande responsabilidade colher da paisagem e então transmitir um olhar, como se o artista fosse capaz de nos dizer sobre coisas que ainda não temos. Consigo ver o Urubu ou construo esse espaço com o que já tenho dentro de mim? Consigo ver e/ou tornar visível? Contemplo a exterioridade ou minha própria construção intelectual? A busca pelo fantasmagórico, pelo invisível, se dá diante de mim. As coisas que vejo podem estar ocultas para os outros e, dessa forma, minhas limitações de olhar, ao diferirem, podem oferecer um mundo novo.

O espaço, constituído no visível e capturado para o vídeo, é uma evidência que pode desdobrar-se, quando os implícitos podem ser testados, quando outras evidências podem ser feitas e refeitas, quando a textura da forma pode ser tateada. Os elementos podem ser (de)compostos “à beira dessa floresta de símbolos que é a história da edificação da paisagem, que foram suas condições de possibilidade"40. Filma-se para ver antes da dobra, para antever. 


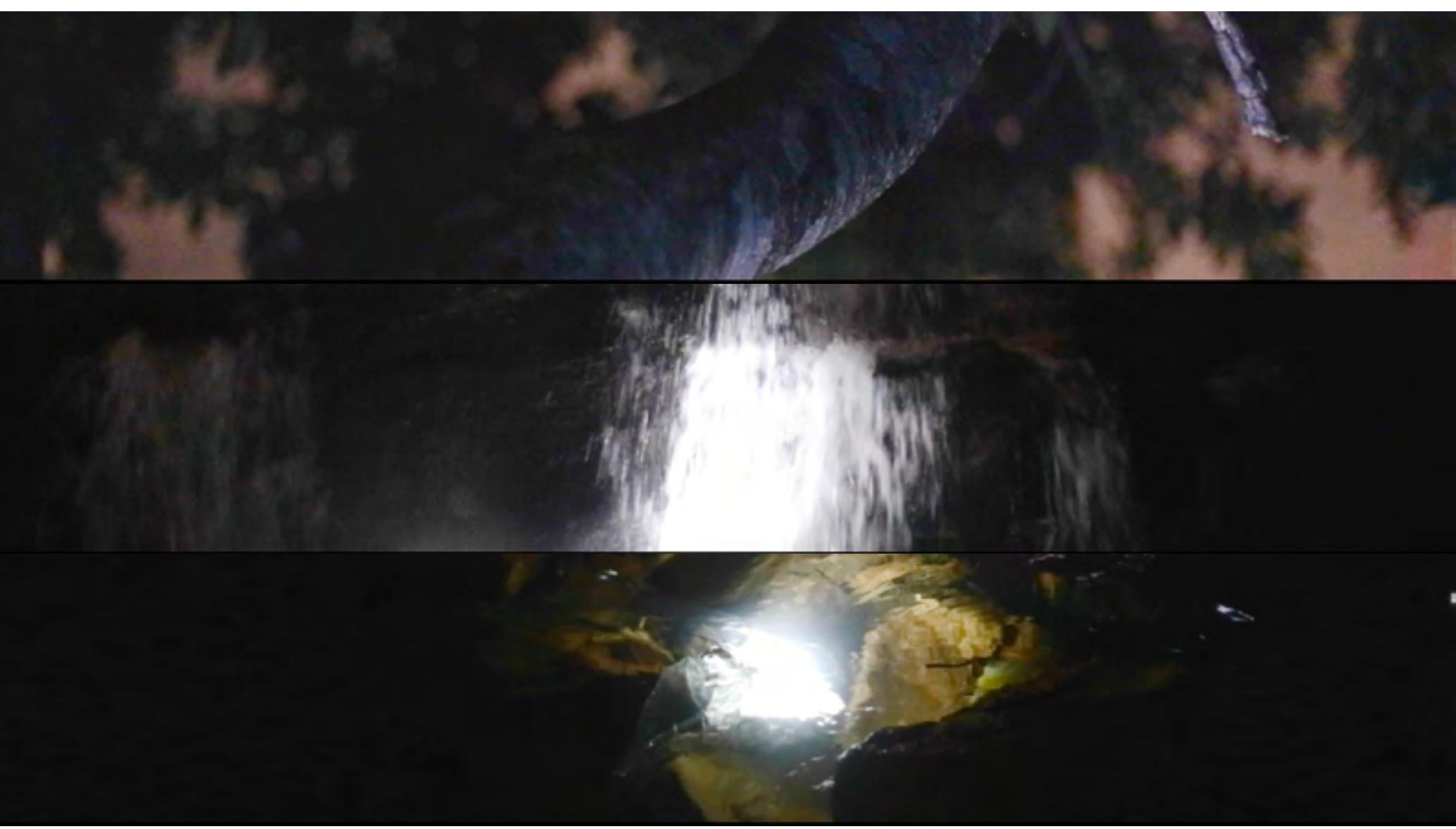

Imagens de Áruore Parada, Maurício Chades, 2015

Para o senso comum o Urubu não se parece com uma floresta. Muitos justificam essa opinião dizendo se tratar de um espaço muito pequeno ou porque as árvores não obstruema visão. Dessas afirmações, entendi que esperam que as florestas tenham dimensões maiores de espaço e também esperam ser cegados pelas árvores, ou seja, é preciso perder-se nesse ambiente. Parecem mesmo lembrar-se de bosques estrangeiros mostrados nos filmes. Só é possível perder-se em lugares imensos, parecem me dizer, mas não percebem que o lugar "gigantesco" pode não tratar de referência baseada em escala? Quando a imensidão é "interior", o Urubu pode ser floresta. Se as florestas são o que você lembra delas e são sempre menores quando você retorna a esses espaços, é mesmo a "imensidão" medível em metros? Não é preciso permanecer muito tempo nos bosques para conhecer a impressão sempre um pouco ansiosa de que "mergulhamos" num mundo sem limites. Em breve, se não soubermos aonde vamos, já não saberemos onde estamos. "Será fácil reunir documentos literários que sejam variações sobre o tema de um mundo ilimitado, atributo primitivo das imagens da floresta" ${ }^{41}$. Só se desdobra a imensidão quando se pode perceber a riqueza de ele- 
mentos colhíveis em um espaço. Se consegues soletrar os elementos como os componentes indiscutíveis, o bê-á-bá do mundo, "aprendemos a distinguir suas formas, a compô-las entre si em proposições, a reconhecer suas marcas" se vê" faz nascer da natureza a paisagem, a separação do simples ambiente lógico - a Torre de TV Digital que se diz inspirada em uma flor do cerrado, as árvores retorcidas como símbolo maior do cerrado e a cachoeira vista à noite com uma intervenção luminosa, desconectada de sua tradicional representação solar.

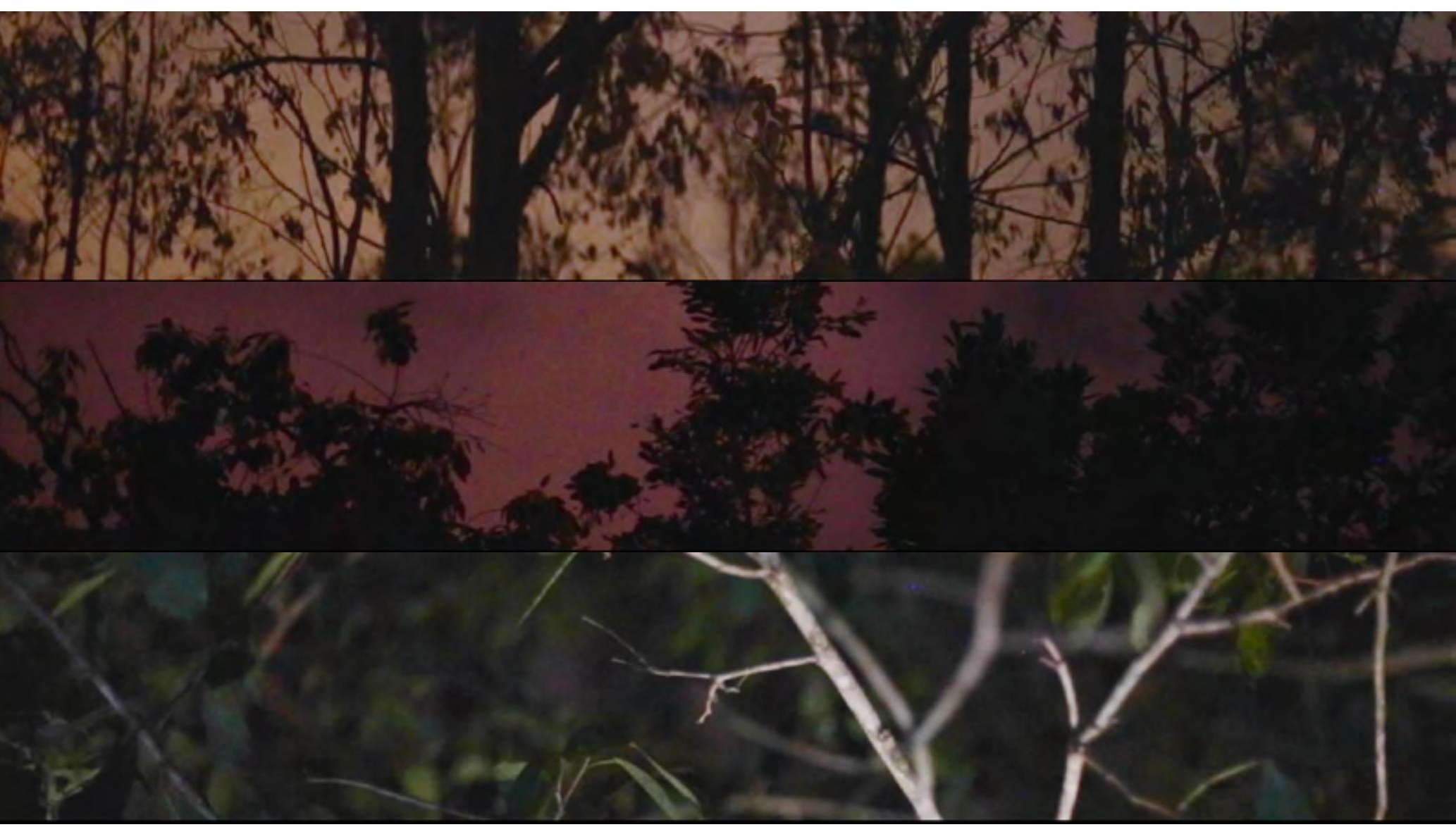

Imagens de Áruore Parada, Maurício Chades, 2015

Descrevo o que vejo e faço uso da linguagem para isso. As árvores, a torre e a cachoeira são alguns dos elementos que, logo percebidos, são colocados na frase. A linguagem parece oferecer a segurança, ser um lugar de claridade, onde não se percebem as sombras - a linguagem parece ser o lugar da evidência. Clareza que desaparece a partir do momento em que se tenta a explicação, a exteriorização, o desdobramento. O que está implícito, dobrado para dentro, está no vasto tecido de todos os planos (proposições) que falam da paisagem. "São as proposições - assim como projetos - das quais 
se espera o 'preenchimento' e a satisfação que formam a sinfonia da expectativa"43, aquilo que se quer ler. O vídeo dá a ver não os objetos, mas o elo entre eles, em uma tentativa de tecer um vínculo de indiscernibilidade entre o que se sabe e o que se vê.

$\mathrm{Na}$ "Floresta Urubu", esperava subir em árvores com mais frequência, assim que as visse e desejasse. Tal expectativa de residir na floresta é frustrada quando as árvores estão entre cercas de arame farpado, quando a estrada de chão é um dos poucos espaços de circulação pública. Muitos pedaços da paisagem só são visíveis de longe, do lado de fora, mirando as árvores nos quintais dos vizinhos ou para dentro de cercados que dão para nada, terrenos fechados onde não há casas e ninguém habita. O "jardim" separa-se da cidade, mas também separa-se da natureza. No Urubu, onde quase tudo é inacessível, cercado, o jardim predomina sobre o lado de fora, a "natureza desértica" ${ }^{44}$. Reintegrar os espaços, ou criar "um fora dentro", são problemas de Árvore Parada. É preciso desfazer as cercas para que se descreva o Urubu. A cerca interferida com tela e projeções torna-se um dispositivo de ver e de acessar, um portal. Um lugar por onde se entra na natureza e por onde a natureza toma o jardim de volta. 


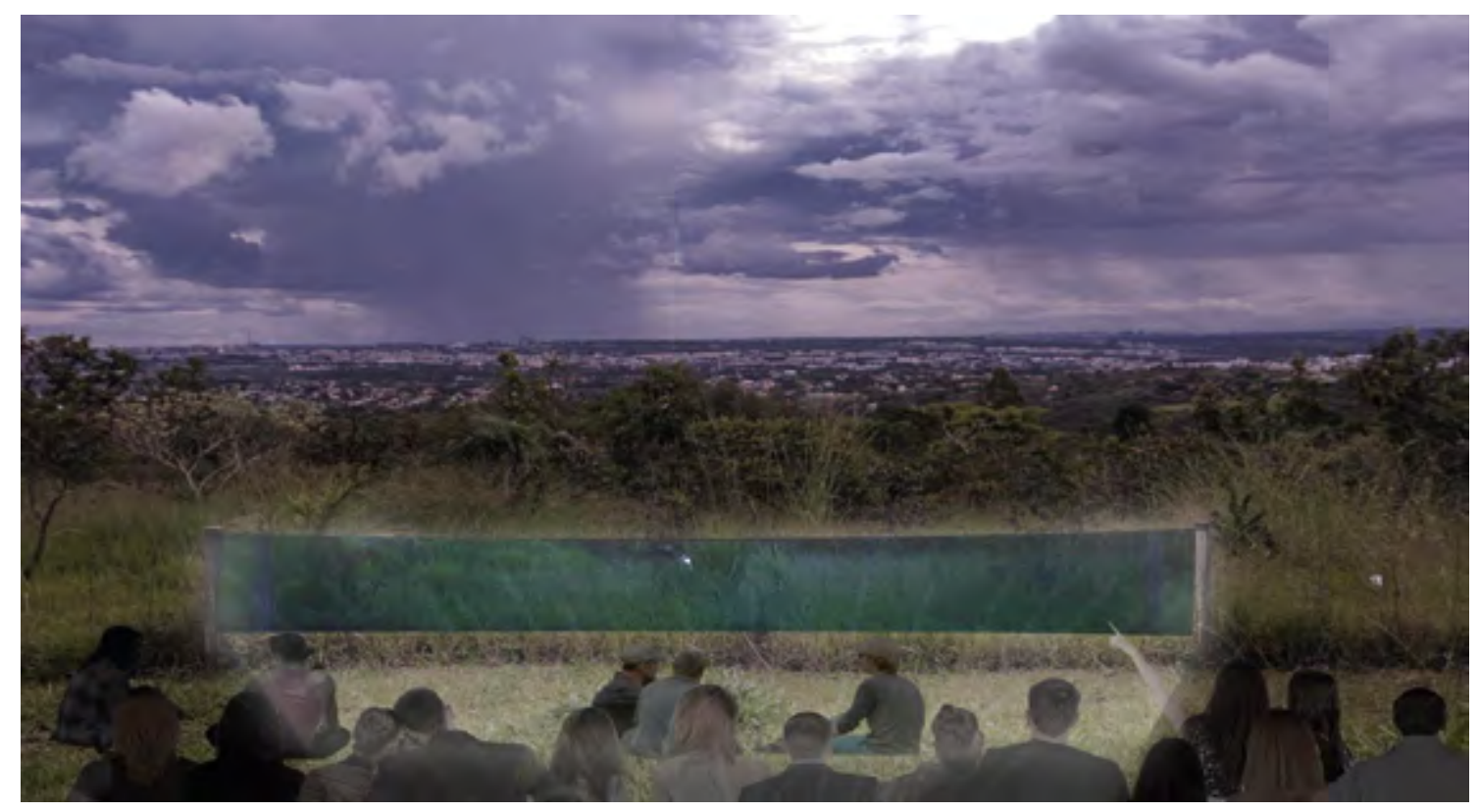

Croqui de Árvore Parada, Maurício Chades, 2015. Pré-visualização desenhada sobre fotografia do quintal do Parque de Produções (croqui: Gabriela Bílá)

Instalar o filme, torná-lo escultura, é uma oferta de vários estímulos que se faz ao espectador. De natureza visual, auditiva, "sensações que demandam a interconexão dos vários sentidos relacionados durante a exploração espacial" 45 . Trata-se de um cinema fora de seu contexto tradicional, a sala preta, um cinema que gera uma situação na qual o espectador participa das imagens como uma experiência no tempo e no espaço. As imagens em movimento se apresentam a espectadores móveis, libertos da cadeira e da sala teatral, o que "coloca sob tensão essa coincidência entre o objeto temporal que é um filme e a consciência, cuja estrutura é, no fundo, cinematográfica" ${ }^{46}$. Afinal, os aparelhos de televisão e as projeções em salas de cinema tendem a colocar os espectadores em posições fixas, de frente para a imagem. A instalação Árvore Parada está no ambiente, envolvendo espectadores, "permitindo que entrem nos espaços da imagem, não evidentemente mediados pela formalidade de uma moldura ou tela"47. Dominique Païni define Cinema Expandido como sendo "a ampliação e multiplicação do espaço da tela"48, dessa forma, Árvore Parada pode ser uma obra pensada dentro deste fenômeno que acontece entre as artes visuais e o cinema, quando propõe o deslocamento das imagens filmadas em uma articulação com o espaço na criação de 
um novo circuito, baseado nas projeções da tela instalada na cerca, artefato onde se tensionam com maior expressividade as questões do trabalho.

O Cinema Expandido opera no lugar da substituição das restrições pelas possibilidades, pelos "e se". Se no cinema tradicional o espectador não pode mover-se enquanto o filme dura 120 minutos, no Cinema Expandido a relação de duração não se mede com precisão, quando o espectador "monta" um filme deslocando-se pelo ambiente, olhando para as imagens projetadas em um momento e explorando o jardim (espaço) em outro. Não há conclusão narrativa nem uma tela (obrigatoriamente) retangular que restrinja o filme. "As projeções oferecem um campo visual tridimensional, sem matriz espacial ou temporal, que particularmente dispersa em vez de unificar a subjetividade"49.

INTERVENÇÃO E REMEDIAÇÃO

Já não consigo separar das imagens o que tento de puramente ótico das minhas intervenções na paisagem intencionalmente artificiais. O circuito atual-virtual se impõe na situação ótica-sonora, no que constitui a "imagem-tempo". o puramente ótico está em tentar um esvaziamento na imagem, de estímulos visuais, de "cinematografia", tentativa frustrada quando percebo que o "vazio" também está intencionado claramente, quando estou bastante presente ao tentar uma imagem "pura". A câmera não se move e poucas vezes chega perto dos objetos em vista. Colocada sobre o tripé, a câmera também não se inclina em ângulos muito agudos e "expressivos", preservando-se a frontalidade. As imagens, noturnas, são escuras e ora ou outra recebem intervenções luminosas, quando da presença de uma lâmpada fluorescente no centro do quadro, ou da luz estroboscópica instalada entre árvores revelando galhos finos antes apagados. 


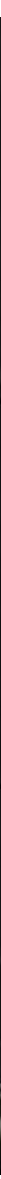

Imagens de Áruore Parada, Maurício Chades, 2015

Muitas vezes, quando o cinema desloca-se da "caixa-preta", seu espaço tradicional preenchido com poltronas confortáveis, ele o faz para outra estrutura confortável e tradicional: a galeria de arte, o "cubo-branco". As instalações em ambientes externos, por sua vez, tendem a repensar um espaço cujo fim não costuma ser aquele de receber imagens projetadas. Quando o espaço apresenta questões e não pode ser ignorado para acomodar uma obra pré-existente, talvez o artista precise percorrer as superfícies e trilhas para revelar ofertas que alí estão sendo feitas. Mesmo na galeria de arte, espaço tradicional e reconhecível, o cinema parece outro e não se deve esquecer, em função da rigidez da estrutura, que um espectador móvel deverá deslocar-se naquele espaço para que a obra, videoinstalação, cinema-instalação, exposição de cinema, aconteça. Em que pese a troca acontecer entre estruturas familiares para a maioria dos espectadores, da caixa preta para o cubo branco, o cinema não é o mesmo quando habita a casa nova e "em todas as situações (no deslocamento para um ambiente externo ou para a galeria de arte) o que se deve ter em conta é que um espaço está sendo apropriado e que se está pensando um lugar que será habitado pelo corpo em movimento"50. 
A dispersão torna-se uma consequência (e objetivo) quando põe-se o corpo a deslocar para ver. O cinema é lembrado como arte da contemplação, teatro escuro onde senta-se e concentra-se durante 2 horas de silêncio para que absorva-se ao máximo as imagens e sons provenientes de uma única fonte, o projetor atrás das cadeiras e o som realista que veda o filme do mundo lá fora. No cinema de exposição, também se propõe um "bom aproveitamento" da experiência, mas as possibilidades são múltiplas para o espectador que se aventura a percorrer, a olhar ao redor, a dar as costas às imagens e ver o que acontece um pouco mais adiante, pois é possível olhar para outras telas e ouvir das mais diversas fontes sonoras. O cinema de exposição opõe-se ao cinema tradicional que mostra uma imagem após a outra, em um encadeamento a que se dá o nome de montagem, quando as imagens desenrolam-se como em um carretel, a timeline. Quando se instala uma obra no espaço, os planos se sobrepõe e a montagem se dá em uma justaposição de tempos e quadros, entre um virtual e um atual que alternam entre o contexto (espaço) e o projetado.

Optei não mover a câmera para que percebesse melhor o movimento que está no interior da imagem, muitas vezes as luzes que piscam em um intervalo mínimo na cidade lá longe, constituindo uma imagem quase tão estática quanto a fotográfica. "Uma imagem dita fixa pode apresentar movimento? Uma imagem dita movimento pode apresentar imobilidade?"51 nos pergunta André Parente, "Como lidar com a desaceleração e congelamento da imagem nos filmes? É possível fazer um filme de imagens fixas? O movimento é sempre visível ou não?" 52 A fixidez foi a alternativa escolhida ao movimento. A câmera de cinema tradicional, que segue os passos das personagens, que faz movimentos dos quais ela apenas é objeto, subordina a descrição do espaço a funções do pensamento. Aqui, a câmera está fixa porque precisa reposicionar-se como agente da imagem, "não é a simples distinção do subjetivo e do objetivo, do real e do imaginário, é, ao contrário, a indiscernibilidade deles que vai dotar a câmera de um rico conjunto de funções, e trazer consigo uma nova concepção do quadro e dos reenquadramentos"53. Ao mesmo tempo que o movimento mínimo, entre uma câmera fixa e objetos no interior da imagem quase estáticos, são uma tentativa de extrair o movimento do móvel, para tentar chegar em uma indiscernibilidade entre a imagem e o objeto. "A imagem-movimento é o objeto, é a própria coisa apreendida no movimento como função contínua", enquanto Árvore Parada tentar ser "imagem-tempo"54, uma imagem ótico sonora pura, não subordinada aos objetos que tentam condicionar o comportamento da câmera, uma imagem sem funcionalidade.

51 PARENTE, 2013, p. 94.

$52 \mathrm{Id}, \mathrm{Ib}$.

53 DELEUZE, 2009, p. 34.

54 Id, p. 40. 


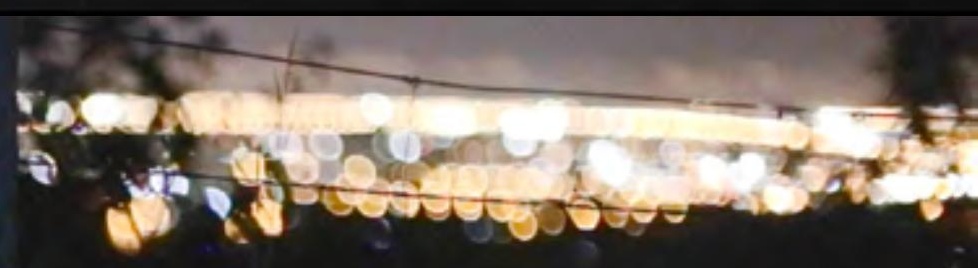

Este trabalho tenta possibilitar ao espectador ver e talvez seja por isso que as imagens não são iluminadas, revelando todo o cenário que se esconde enegrecido na noite. $O$ vídeo projetado possui imagens escuras, noturnas, e as projeções da instalação também são exibidas à noite, de forma que a obra relaciona-se com um apagamento do visível, para que a pupila adapte-se à noite, dilatando-se, para que novas formas de ver façam-se evidentes. Ora, se oferecesse mais a ver que imagens escuras, acredito que estaria dando mais chances para mim e para os espectadores de ver menos, "apenas o que estamos interessados em perceber, devido a nossos interesses econômicos, nossas crenças ideológicas, nossas exigências psicológicas" 55 . O exercício é tentar escapar o clichê, já que comumente é apenas o que vemos. É necessário tentar bloquear ou quebrar nossos esquemas sensório-motores, para então perceber outro tipo de imagem: "uma imagem ótico-sonora pura, a imagem inteira e sem metáfora, que faz surgir a coisa em si mesma, literalmente, em seu excesso de horror ou de beleza, em seu caráter radical ou injustificável, pois ela não tem mais de ser 'justificada', como bem ou como mal”56. 
A tela na cerca que recebe imagens projetadas colhidas na própria paisagem coloca a dimensão da mímeses no trabalho. "Todo dispositivo tecnológico pode, com seus próprios meios, jogar com a dialética entre semelhança e dessemelhança, analogia e desfiguração, forma e informe" ${ }^{57}$, como se a invenção em si fosse técnica, não estética. Como se a possibilidade de apagar a cerca através da mímese fosse uma condição, meta, já que o dispositivo projetor-software-de-mapping-tela me oferecem tal possibilidade e o mercado de projeções tensiona essa questão todos os dias, a cada mostra, festival e exposição em que o público sai boquiaberto após ver grandes monumentos arquitetônicos serem implodidos com o auxílio do videomapping. A invenção, em matéria de imagem, é estética, nos lembra Dubois. Dessa forma, a tela sobre a cerca é um espaço, um novo hábitat para a paisagem, na paisagem, o que se coloca também como um espelho, um reflexo e, portanto, pode também apagar a cerca e tornar os dois espaços, tela e contexto, uma única paisagem. A queda da cerca é possível em Árvore Parada para quem continua a obra no imaginário, entre suas tensões, suas lacunas, entre o que há de semelhante e dessemelhante no processo de reconhecer o primeiro plano e o fundo enquanto dialética mimética.

Não quero produzir a mesma imagem que continua logo ali, no fundo da projeção. Tento produzir um diálogo com os elementos do espaço da matéria e, consequentemente, produzir novos elementos entre os estímulos causados na projeção/espaço. "A imagem tem de ser pensada movendo-se para fora da moldura e dialogando com o que está a seu redor"58. O artefato arquitetônico construído, a instalação, é tanto meio como também "conteúdo", não funcionando apenas como uma escultura que poderia ser deslocada e instalada entre diferentes salas domésticas ou salas de galerias. A tela instalada na cerca transfere para o vídeo projetado novos elementos que, por sua vez, espalha-se pelo contexto, remodelado.

O efeito do retângulo-tela instalado na cerca, diante da paisagem, na paisagem, é a colagem. A imagem projetada, digital, é "dramatizada pelo dispositivo" 59 que faz desempenhar outros papeis no espaço atual. O espaço e a cerca são remodelados, reajustados, em um processo que Arlindo Machado chama de remediation (remediação) e o exemplo mais eloquente seria a tela do computador, "na qual se pode ter, superpostas ou lado a lado, várias janelas abertas, com textos numa, imagem noutra, fotografias em outras mais, além de vídeos, filmes"60, e assim, de forma semelhante à paisagem, o computador é um mundo que dá-se a ver pela incrustação de elementos no espaço, na justaposição de textos e vídeos, uma edição e seleção de elementos em

57 DUBOIS, 2011, p. 57.

58 DOMINGUES, 2002, p. 146.

$59 \mathrm{Id}, \mathrm{p} .149$.

60 MACHADO; MACIEL, 2008, p. 66. 
uma hierarquia do ver mediada pelo interesse: a aba do texto que quero ler pode vir para a frente e esconder outras, mas pode voltar para trás, desaparecer, quando uma fotografia tornar-se mais interessante.

Para o artista que trabalha com videoinstalações inseridas em um espaço específico, o contexto é da maior importância. Apichatpong Weerasethakul, artista e cineasta tailandês, imergiu no povoado Nabua durante anos realizando uma série de trabalhos entre cinema, videoinstalação e performance, a série chamada The Primitive, que agrupa os curtas-metragem A Letter to Uncle Boonmee (2009) e Phantoms of Nabua (2009) e o longa-metragem Tio Boonmee, Que Pode Recordar Suas Vidas Passadas (2010), vencedor da Palma de Ouro no Festival de Cannes em 2010. Apichatpong, apelidado de "Joe", investiga o território tailandês em um impulso etnográfico, descortinando lençóis de tempo e memória, transitando entre a paisagem rural e a urbana, acessando passado, presente e futuro, tempos sobrepostos no mesmo quadro, uma imagem-tempo. Joe registra "carinhosamente superstições siamesas, formas folclóricas e contos populares, ao sentido modernista da ambiguidade, da falta de confiabilidade na verdade e de que todo conto é fabricado" ${ }^{1}$.

A primeira imagem de Phantoms of Nabua revela um quadro escuro, sem iluminação artificial quando única fonte luminosa é o céu de uma noite sem lua. A copa das árvores, em um contraluz com o céu, são uma silhueta negra que move-se lentamente e, diante dela, uma lâmpada fluorescente instala-se como um artefato industrial estranho à floresta. É preciso apertar os olhos para perceber melhor a imagem quase invisível, a tela quase preta, e ouvir bem o silêncio ensurdecedor, o som ambiente da floresta. 


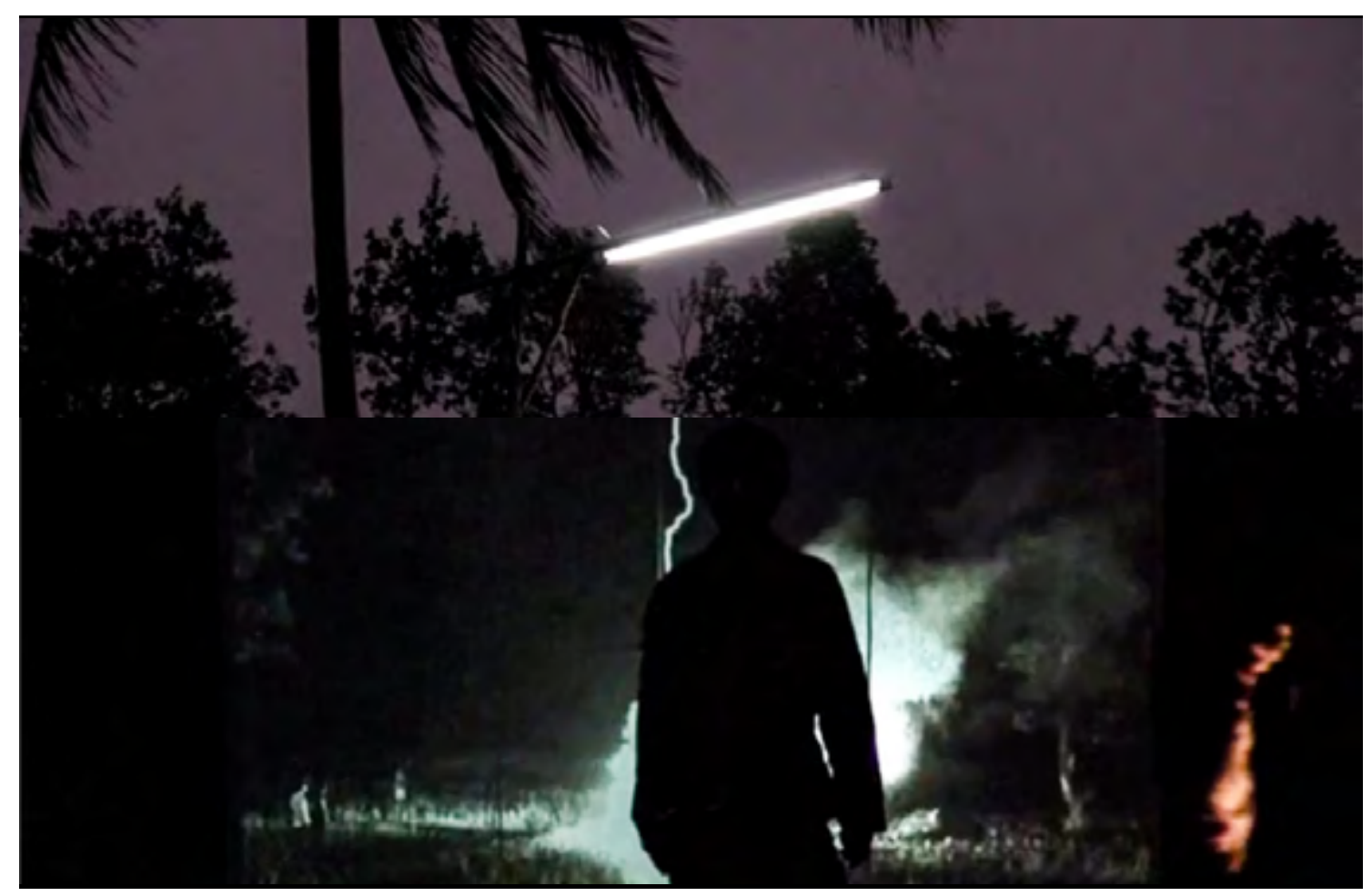

Imagens de Phantoms of Nabua, Apichatpong Weerasethakul, 2009

Ao longo do curta, Joe ainda insere uma tela instalada em uma clareira entre árvores, um projetor que aponta para a tela e uma bola de fogo que será chutada durante o vídeo por garotos, moradores locais. No final do vídeo, a bola de fogo deverá queimar a tela, quando as imagens projetadas perderão superfície de contato para fixarem-se, ora apegando-se à fumaça do tecido queimada, ora sendo uma luz colorida e dispersa.

Artefatos luminosos de diferentes origens são analisados na escuridão. A bola de fogo é arremessada de um lado a outro do campo, revelando vultos de garotos, humanizados pelas risadas, pelo som, enquanto a imagem investe na fantasmagoria. A lâmpada fluorescente está suspensa sobre o campo e a tela, fonte de luz secundária, que está tensionada na zona de risco até desaparecer em fogo e, o projetor, até então subentendido em seu esconderijo, passa a protagonizar. Quando as imagens projetadas dispersam-se no ar, constituindo nada, nos esbarramos mais uma vez com o som da floresta, que melhor mostra e melhor descreve, quando a fotografia já foge de tal propósito. "À noite, a selva não é visual; confia-se mais no som. Ela se torna outra: espiritual, misteriosa" ${ }^{62}$. 


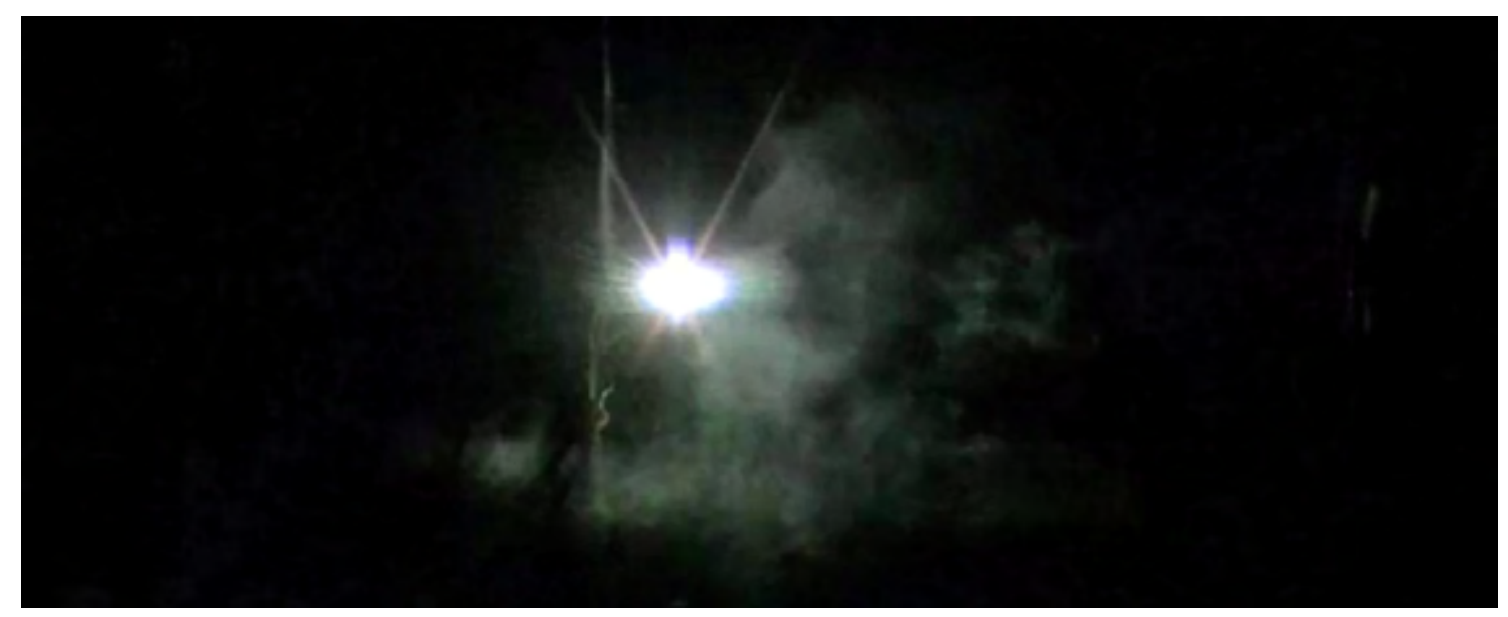

Imagem de Phantoms of Nabua, Apichatpong Weerasethakul, 2009

Apichatpong é comumente registrado com espanto na maioria dos textos da crítica de cinema. Dos comentários perplexos sobre a obra de Joe encontrados em blogs, jornais, revistas e trabalhos acadêmicos, o mais recorrente é que seus filmes "defy categorization"63. Matthew P. Ferrari, em sua tese Mysterious Objects of Knowledge: An Interpretation of Three Feature Films by Apichatpong Weerasethakul in Terms of the Ethnographic Paradigm, sugere que esse tipo de comentário evidencia que os filmes de Apichatpong "necessitam de novos modus de leitura e interpretação". O tom da crítica costuma ser automático, optando por locuções de espanto, de rendição, de invocação do enigma cósmico e da irracionalidade poética, do indeterminado, do inefável e do onírico, "aparentemente para impedir ou prevenir o árduo trabalho de interpretação"64.

Talvez, quando consegui(r)mos "ler" Apichatpong, mais uma vez cairemos no clichê, que parece ser um fim inevitável. A imagem parece sempre retornar a essa condição, aos encadeamentos sensórios-motores, "porque ela própria organiza ou induz seus encadeamentos, porque nunca percebemos tudo o que há na imagem, porque ela é feita para isto"65, para que o clichê nos encubra a vista. É como se precisássemos nos apegar a Apichatpong agora, enquanto ele é atual, enquanto ele nos propõe desafios, antes que ele seja diluído em um processo de (re)produção de clichês, a linguagem. Se isto acontecer, perderemos a chance de conhecer Nabua e seus fantasmas. Teremos o olhar novamente entediado, acostumado em perceber a descrição como fracasso. 


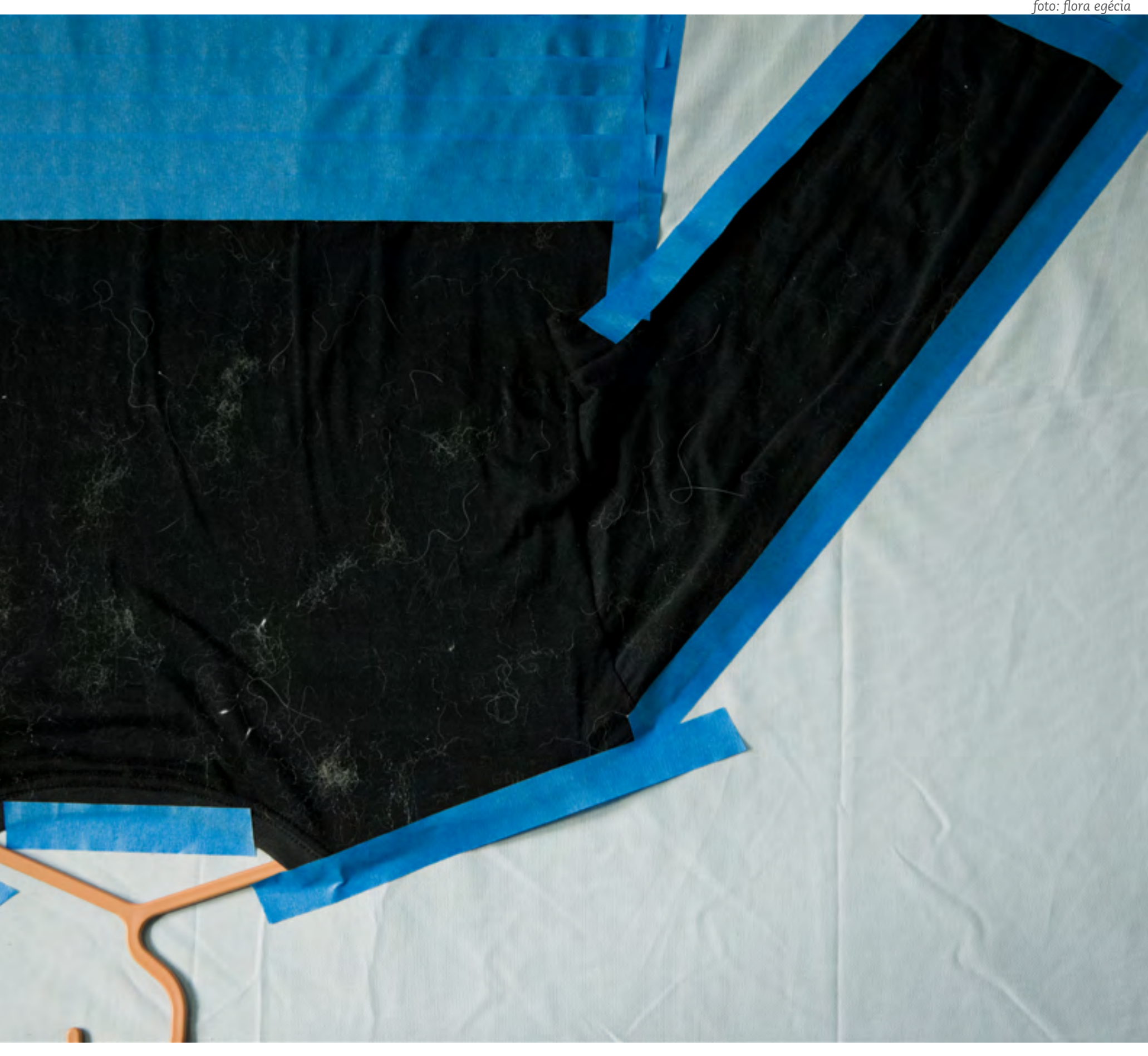

ENSAIO 2: ROUPA BRANCA

vídeo: https://youtu.be/veOpYxoPRoY 
eu ando em direção ao guarda-roupas. o ângulo do quadro, um plano médio em contraplongée, não me revela muito: apenas a tampa da minha cabeça aparece na imagem. no centro do quadro, uma lâmpada fluorescente está acesa. ambiente e passos.

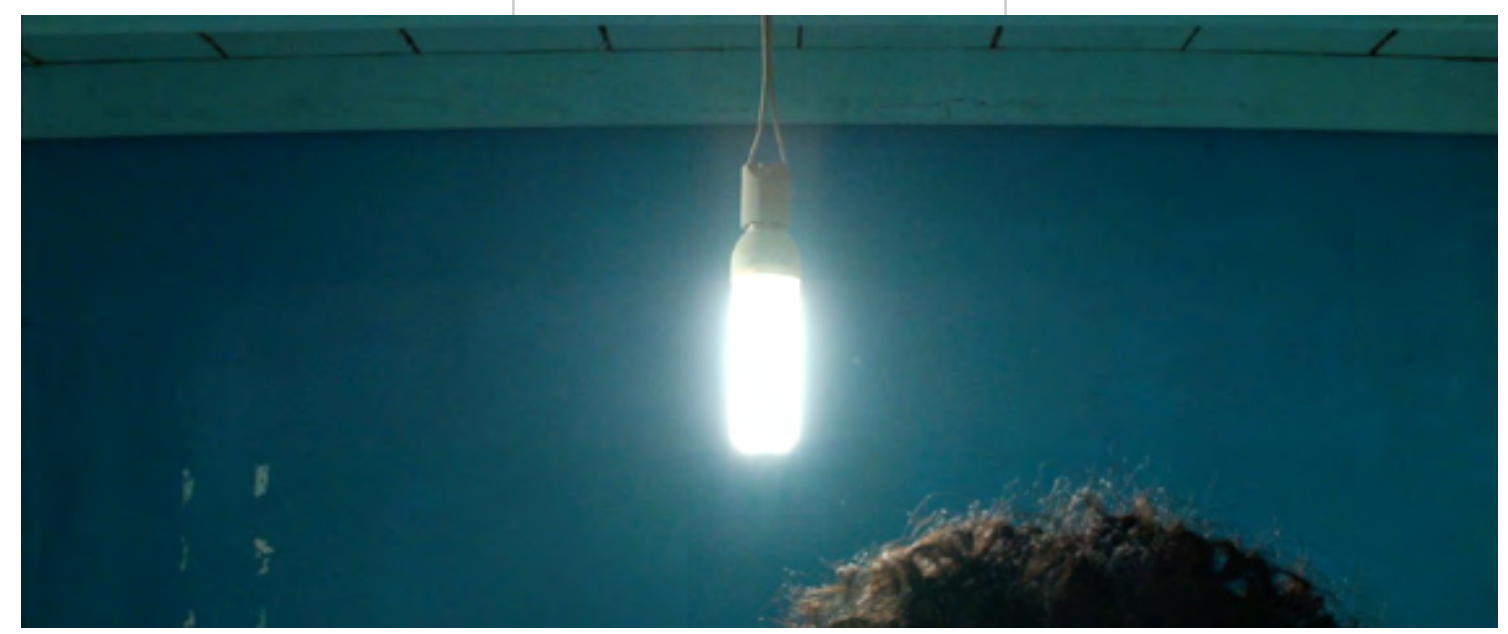

Imagem de Roupa Branca, Maurício Chades, 2015

Não existe imagem pura que se sustente. Desde muito cedo o cinema sofreu os esforços de ser conformado em uma linguagem, passível de ter palavras e frases que se repetissem de filme a filme, como se pudessem sempre dizer as mesmas coisas, constituindo uma gramática inteira de signos-clichê, aplicáveis e recombináveis entre títulos de diferentes cineastas. Dessa forma, produziu-se muito, entre filmes e textos, sobre uma imagem considerada "pura" no cinema, como se um filme pudesse ser mais cinematográfico do que outro, por aproximar-se mais do Cinema e afastar-se

66 Os documentos de decupagem dos vídeos Roupa Branca, Buraco Branco, 'Caixão, Continente', Nunca vi meu pai sem bigode e 'Corpo, Continente' estão colocados entre as páginas dos ensaios como uma forma de perceber quando os conceitos levantados se aproximam e provocam os vídeos, ou o contrário, quando o vídeo provoca o texto. A decupagem está organizada em três colunas: ação, imagem e som. Apresento também, abaixo da decupagem, a imagem do vídeo a que se refere a ação descrita. 
mais daquilo que não seria cinema, mas outra coisa, talvez vídeo. Na década de 1980, o discurso ontológico perdeu o lugar, quando a busca pela imagem pura já não se sustentava, assim como nunca resistiu em nenhuma outra prática artística, da pintura à performance. “Foi-se o tempo das 'especificidades' e das demarcações categóricas. É o momento do contrabando, da visão transversal e do pensamento oblíquo"67.

É um hábito antigo e recorrente entre alguns cineastas, críticos e cinéfilos tentar demarcar as fronteiras do cinema, a expressão do audiovisual dignificada por eles como superior. "Daqui para alí já não é cinema, é vídeo”, eles tentam alertar, estabelecendo uma sabatina a ser cumprida pelas obras cinematográficas. "Com essa câmera não se faz cinema”, "Isso não parece cinema", "Parece filme de televisão". Ainda hoje, textos como A linguagem Cinematográfica, de Marcel Martin, são centrais nas bibliografias dos cursos de cinema, fazendo ecoar o espírito purista, insistente. Plongée, contraplongé68 ${ }^{6}$, movimentos panarâmicos, tilt, zoom, tipos de enquadramento, tipos de angulação, são alguns elementos comuns na tipificação da imagem, utilizados pelos realizadores audiovisuais e que ora fazem uso desses recursos na construção de narrativas cinematográficas, ora refutam tal sistema para libertar-se e possibilitar que outr cinema apareça. A especificidade, aquilo que seria próprio do cinema, parece oferecer segurança, facilidades aparentes, mas talvez o cinema possa recorrer ao vídeo, enquanto maneira de pensamento, para se recombinar e se atualizar. Comemente, o vídeo compreende suas potências de devir: Dubois nos fala que só podemos pensar vídeo seriamente como um "estado"69, "estado do olhar e do visível, maneira de ser das imagens". Dessa forma, o vídeo não conforma-se em ter especificidade e ser mídia, seja como imagem, seja como dispositivo.

A mídia eletrônica opera numa fronteira de interseção de linguagens, donde a obsolência de qualquer pretensão de pureza ou de homogeneidade, quando as tentativas de estabelecer o que é certo e o que é errado no cinema tornam-se movimentos de contrafluxo. De fato não existe uma gramática normativa, uma tábua de valores que estabeleça o que se pode e o que não se pode fazer em cinema, mas é evidente que

67 DUBOIS, 2011, p. 177.

68 O cinema é uma língua (langue) ou meramente uma linguagem artística (langage)? Essa é uma questão amplamente debatida desde Linguagem e Cinema de Christian Metz. O autor defende que o objetivo da cine-semiologia deveria ser o de "extrair, da heterogeneidade de sentidos do cinema, seus procedimentos básicos de significação, suas regras combinatórias, com vistas a apreciar em que medida essas regras se assemelhavam aos sistemas diacríticos de dupla articulação" (METZ; STAM, 2011, p. 129). Metz, problematiza, portanto, se o cinema pode ser lido à luz da linguística estrutural. Nesse sentido, uma série de outros textos de cinema se esforçam em tipificar as imagens do cinema: plongée (mergulho, em francês), por exemplo, refere-se a quando o ângulo da câmera aponta de cima para baixo. Em A linguagem cinematográfica, Marcel Martin limita o efeito do plongée ao de ser uma imagem "esmagadora" (MARTIN, 2003, p. 253), sendo que o contrário, o contra-plongée causaria na imagem um efeito de exaltação da personagem, que se torna maior devido ao ângulo, de baixo para cima.

69 DUBOIS, 2011, p. 23. 
sua trajetória comumente rejeitou abrir-se para propostas de realizar e instalar de outras formas, de recomeçar o cinema, de torná-lo vários. Para além da caixa preta, dispositivo único de consumo, o cinema também tentou conformar-se pela linguagem, quando filmes norte-americanos podem ser assistidos sem legendas em países do Oriente sem que se compreenda o inglês e ainda assim ter a história entendida pelo público. Tal aspecto talvez não se refira a uma estrutura mitológica, nem arquetípica, nem transcultural ou a uma linguagem dita "universal", mas a um grande esforço do cinema americano em tornar-se língua colonizadora. Mas "o cinema não é língua"70, nos conta Deleuze, ele traz à luz uma matéria inteligível, "que é como um pressuposto, uma condição, um correlato necessário através do qual a linguagem constrói seus próprios 'objetos' (unidades e operações significantes)"11.

Alguns filmes dos anos 1980 e 1990 tornam-se esse espaço para o cinema deslizar por meios, por estados, de forma semelhante a como faz fazia o vídeo, portanto, podendo pensar e recombinar-se nas suas possibilidades, problematizando um "como fazer ainda?" Como lidar com a tradição é a questão para os cineastas "maneiristas"72, assim apelidados por Dubois, um grupo atuante principalmente nas duas últimas décadas do século 20 e que tentou tornar o cinema um espaço de passagens, de reflexões e outras representações da imagem. "Como filmar hoje, depois de tudo, uma cena de amor, um diálogo, um assassinato, um beijo? Todo o peso da tradição anterior e de sua excelência está lá e ele pesa e chega a bloquear o trabalho do cineasta"73.

Opto fazer leituras de imagens dos filmes Videodrome: A Síndrome do Vídeo (1983, David Cronenberg) e O liuro de Cabeceira (1996, Peter Greenaway) que propõem evidenciar a imagem tecnológica de onde emergem, um forte sintoma do cinema desse período. Ambos filmes praticam um tratamento visual da imagem que nos lembram que o cinema é uma experiência mediada por dispositivos tecnológicos, diferente de outro cinema que tente nos colocar em uma relação de passividade, quando guiados da imagem projetada a uma simulação de sonho, imagem simulada. A relação com o espaço, o enquadramento, os movimentos de câmera, as diversas trucagens e os efeitos de diagramação, que dividem a tela em várias, desdobrando o espaço filmado na superfície do quadro, desses filmes nos mostram mudanças e possibilidades fundamentais para o cinema contemporâneo. São filmes que refletem a chegada da teleclastia praticada por artistas como Nam June Paik ${ }^{74}$ ao cinema, artistas que optam

70 DELEUZE, 2009, p. 211.

$71 \mathrm{Id}, \mathrm{Ib}$.

72 DUBOIS, 2011, p. 149.

$73 \mathrm{Id}, \mathrm{Ib}$.

74 O coreano Nam June Paik estudava música eletrônica com Stockhausen quando teve a ideia de reverter os circuitos de um aparelho de TV, reconfigurando e deformando as imagens figurativas recebidas. O artista dava início à teleclastia, um dos temas mais recorrentes na produção de videoarte até hoje. Os Distorted TV Sets que Paik concebeu a partir daquela técnica elementar repre- 
por destruir e alimentar-se da TV, do vídeo, para reconstituir as partes quebradas em novas combinações.

Max Reen, interpretado por James Woods, precisa descobrir novos conteúdos para a programação do canal de televisão em que trabalha e lhe surge a oferta de exibir videodrome, uma espécie de programa pirata, de apelo à violência e sexualidade, até que começa a se questionar se as torturas sofridas por uma mulher nua no interior do vídeo tratam de encenação ou de uma ação real. Com o surgimento de videodrome, os programas eróticos japoneses, de encenação falsa e pitoresca, automaticamente tornam-se caretas e ultrapassados aos olhos de Max. O "circo do vídeo" parece oferecer um frescor de novidade para o destrutivo cenário da televisão, que investe em uma corrida por audiência e popularidade.

Em videodrome, apenas vemos "tortura e assasínio. Sem enredo nem personagens, muito, muito realista. Eu acho que é a próxima moda", define uma personagem em um momento de claridade. "Antes na TV que nas ruas", alerta, porém, muito tarde, quando no contexto do filme já não discernimos com facilidade alucinação de lucidez, televisão de cinema, vídeo de vidência, biológico de tecnológico. Se Videodrome nos mostra uma ação de tortura real, "quando o sangue não é ketchup"75, quando os corpos não são colocados em uma fabulação narrativa com personagens e enredo, talvez Videodrome nos fale bastante sobre uma atualidade do corpo presente na performance e na videoarte.

David Cronenberg investe em um visual inusitado na tentativa de criar um "corpo do vídeo", um vídeo sensível e vibrátil, para onde Max aponta e projeta suas pulsões sexuais. A partir de alucinações, Max passa a enxergar traços de uma corporeidade biológica e sexual nos dispositivos mediadores: uma televisão que geme, respira e chama por ele com uma voz feminina sensual; a superfície da máquina sensível e pulsante como a pele humana, que reage com tesão quando tocada. Cronenberg faz uso de efeitos visuais, de maquiagem e cenografia na representação do corpo do vídeo. Em uma cena ambientada num estúdio de TV, Max flerta com a colega de palco oferecendo-lhe um cigarro. A câmera nos mostra Max enquanto fala e desliza até Nicki em um movimento para mostrá-la respondendo que "não, obrigada". Vemos a personagem através do monitor do estúdio, mediada pela imagem filmada em tempo real, habitando um novo corpo, tecnológico.

sentaram algumas das primeiras imagens não figurativas ou "abstratas" da televisão, sintetizadas através do puro tratamento eletrônico do fluxo de partículas no iconoscópio.

75 Jargão proferido por Marina Abramovic, "dama da performance", em diversas ocasiões, sendo uma delas em uma palestra para o portal TED em 2015. link acessado em julho de 2016: https:// goo.gl/j2rHF5 


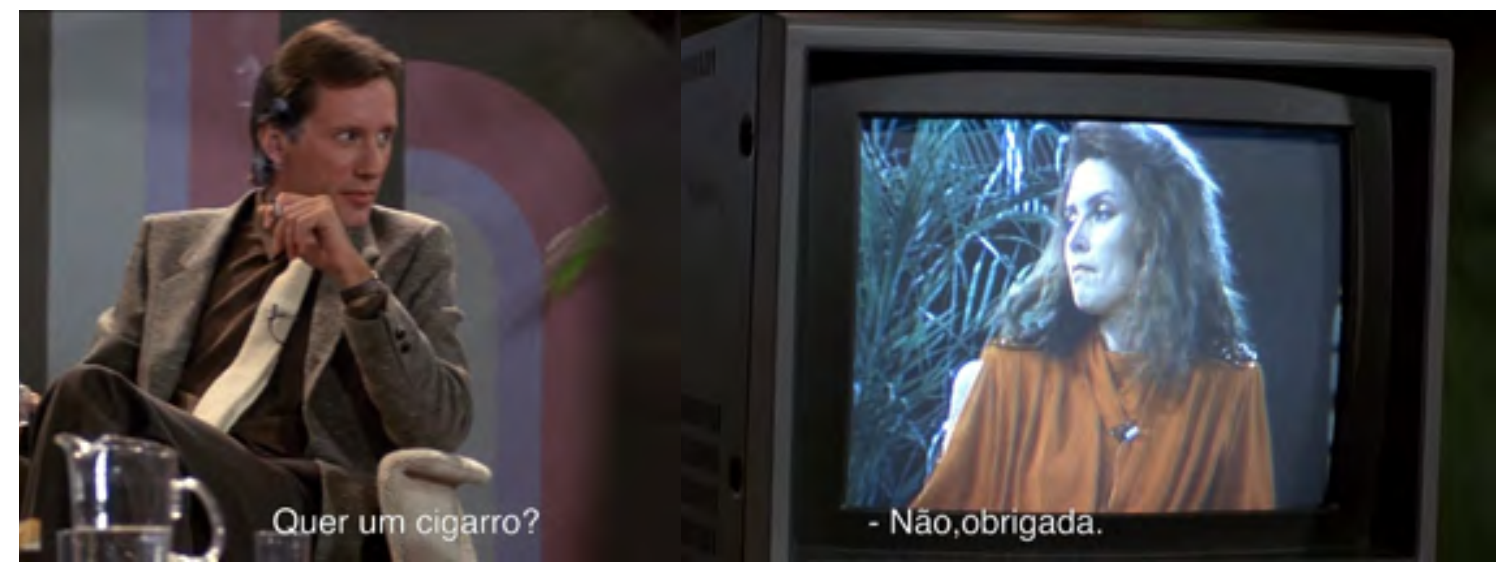

Imagens de Videodrome: A síndrome do vídeo, David Cronenberg, 1983

Entre as tentativas de investigar as origens de videodrome, Max passa a ser assombrado pelo professor Brian O'blivion, uma espécie de vidente do video, cuja forma corpórea se dá entre fitas cassete reproduzidas na TV. Brian nos fala sobre uma órgão novo que se formou em sua cabeça, causado pelo vídeo (alucinações), um tumor que deverá matá-lo: "visões causam tumores, não o contrário". Para Brian, o órgão novo que cresce em sua cabeça está alí para receber esse novo lugar da realidade, aluciações-vídeo.

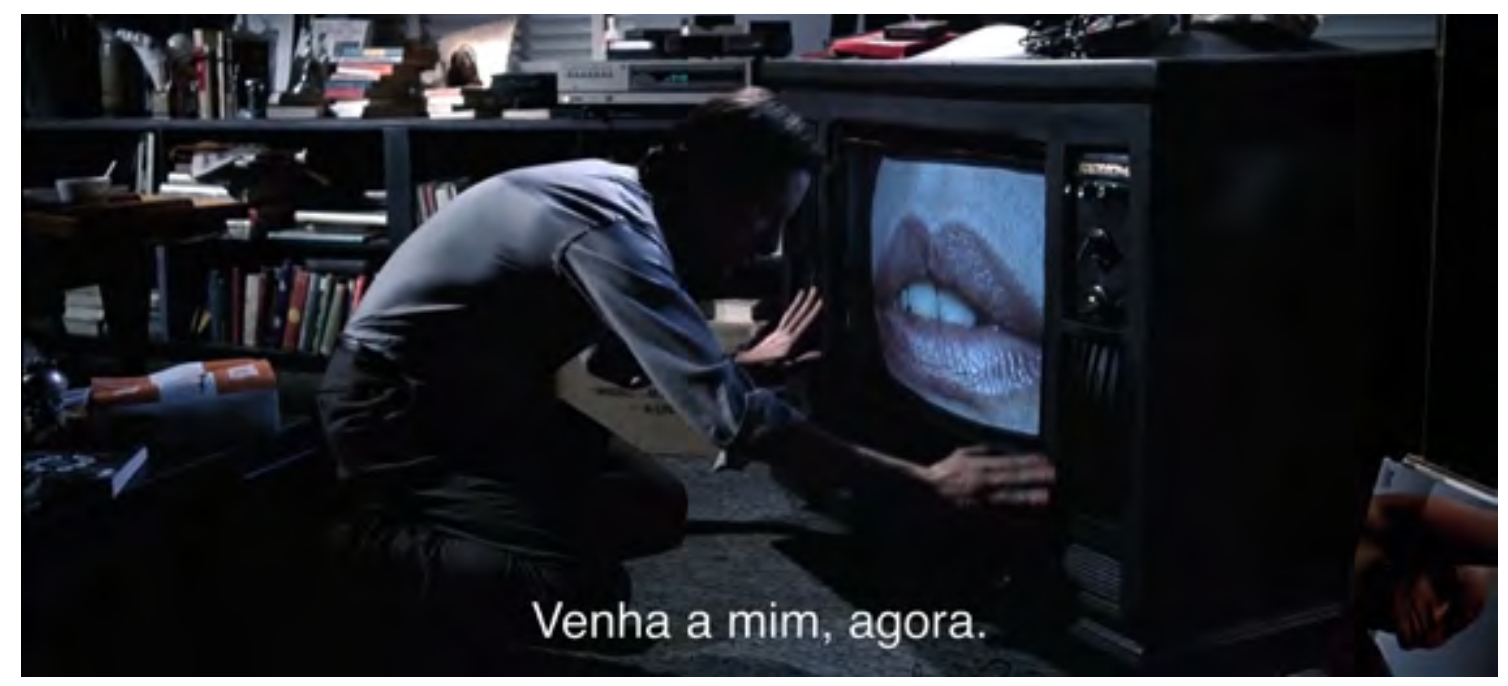

Imagem de Videodrome: A síndrome do vídeo, David Cronenberg, 1983

O Liuro de Cabeceira faz um percurso semelhante (e dessemelhante) ao de Videodrome na tentativa de revelar uma corporeidade do vídeo. Nagiko, estimulada pela mãe, escreve um diário desde a infância, um livro de cabeceira. Trabalho e amor se confundem quando Nagiko faz o mesmo peso para a superfície do papel e da pele humana, espaços onde se pode fixar caligrafias de ideogramas de traços bem elaborados. As palavras e a caligrafia tornam-se a grande motivação de Nagiko, que investe na busca de um amante perfeito, idealizado por ela como o homem que equilibre o talento para 
o amor e para a caligrafia ao mesmo tempo. "O aroma do papel novo é como o da pele do novo amante".

Dessa forma, o filme faz o texto deslizar entre camadas: as ideias e palavras são de Nagiko, a grafia na superfície da pele é por conta de um calígrafo, ideogramas que também são projetados como desenhos de luz nos cenários do filme - "os pensamentos eram dela, mas as palavras eram minhas", reivindica um dos amantes; e, por fim, as palavras são diagramadas no quadro cinematográfico dividido entre telas, sobrepostas e justapostas, entre transparências e opacidades. A superfície da tela, experimentada à exaustão, é espaço para uma problematização de O livro de Cabeceira, a tradição viva, marcada sobretudo pela presença da caligrafia artesanal, coexistindo à atualidade, constante nas possibilidades de uso tecnológico do vídeo na constituição de narrativa hipertextual.

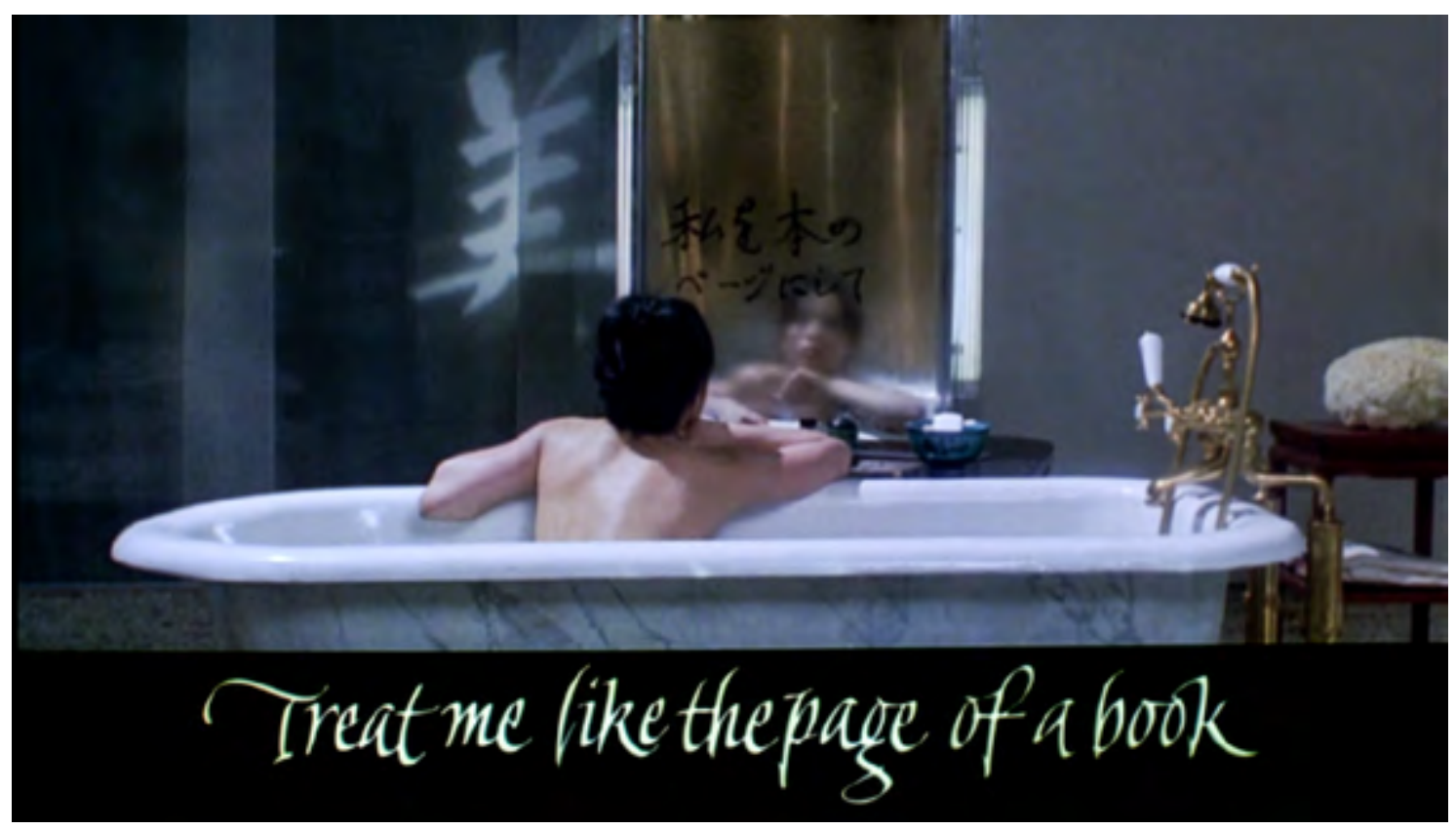

Imagens de O liuro de cabeceira, Peter Greenaway, 1996

O Livro de Cabeceira traz à imagem cinematográfica reflexões fundamentais na compreensão do espaço, do enquadramento, dos movimentos de câmera, através dos efeitos de truncagem e da diagramação de várias imagens em um só quadro. O quadro de cinema, tradicionalmente unitário e homogêneo, "um espaço ainda terrestre, uma imagem estilhaçada e múltipla"76, passou a ser um espaço flutuante, sem lei de gravidade nem vínculo humano. "Em suma, passou de uma representação ainda cinematográfica a uma representação quase puramente tecnológica"77. A tradicional profundidade 
de campo, um dos elementos da linguagem cinematográfica em que o trabalho do diretor comumente é observado, espaço em que se constrói a mise-en-scéne ${ }^{78}$, quando atores e cenografias são colocados em composição, desde o primeiro plano até a parte mais distante do quadro, onde o foco não chega, precisa ser repensada. O trabalho de elaborar o campo, tudo que se dispõe dentro do enquadramento, pode ser reconsiderado quando o quadro não se delimita mais às bordas da lente de uma câmera, mas a um espaço digital pensado em um software de edição de imagens. "Muitas vezes já se afirmou que a profundidade interiorizava a montagem na cena, na mise-en-scéne"79 e isso é mais evidente quando a montagem passa a ser um processo de colagem no interior do quadro digital, de forma que a profundidade de campo possa reverter a subordinação do tempo ao movimento, "exibindo o tempo por si mesmo"

O cinema moderno é também um cinema do plano, que pensa o quadro como uma superfície onde se coloca tudo, ou quase tudo. À modelo do cinema modal, espaço de reflexão de uma imagem composta digitalmente, o cinema praticado por grupos de cineastas como a Nouvelle Vague ${ }^{81}$ propõe um espaço que se fecha sobre si mesmo, divergindo do cinema clássico que trabalhava a crença de um segredo atrás da porta. “O diretor (metteur-en-scéne) dá lugar ao 'autor', a mise-en-scéne dá lugar à 'escrita' plana"82. A relação do suspense, de algo a se ver atrás, para além das bordas do quadro, já não empolga tanto, o contraste cena/bastidor se enfraquece e o que se coloca diante do público é uma folha em branco, uma superfície luminosa. "É um cinema da frontalidade: tudo está lá, na imagem, na sua superfície, em um só e mesmo plano. $\mathrm{O}$ espectador está de frente, seu olhar bate na tela e ricocheteia"83.

A frontalidade do quadro faz revelar um objetivo de todo cinema e de todo vídeo: alcançar a apresentação direta do tempo. À modelo do cinema direto ${ }^{84}$, já não se pre-

78 Do francês, "por em cena”, trata da orquestração dos diversos elementos necessários para a fabricação do universo fílmico: luzes, atores, cenografia, movimentos de câmera. O termo também é utilizado no teatro com o mesmo fim.

79 DELEUZE, 2009, p. 136.

80 Id, p. 133.

81 A Nouvelle Vague trata de um movimento do cinema francês que rompe com o cinema de estúdio e propõe um laboratório de estéticas fragmentadas, que passou a incorporar o acaso (da rua) nas filmagens, "da polifonia narrativa e de uso de formas até então atribuídas ao documentário, às artes visuais, ao ensaio e à literatura. A Nouvelle Vague fez chegar ao cinema a sua juventude tardiamente, com um pé na maturidade" (MANEVY; MASCARELLO, 2006, p. 221). Além de estimular todo um novo cinema, bastante inspirados pelos movimentos que culminaram em Maio de 68 , a Nouvelle Vague também movimentou produção de artigos, cineclubes, sendo seus principais cineastas, Jean-Luc Godard, François Truffaut, Alain Resnais, pensadores operantes entre essas três atividades: realização de filmes, produção de textos e debates em cineclubes.

82 DUBOIS, 2011, p. 148.

83 Id.

84 O cinema do pós-guerra alimentou-se de várias referências, sendo uma das principais o Neorrealismo Italiano, do qual emerge o cineasta Roberto Rossellini que costumava destacar que, ao se basear na percepção de que o ordinário e o extraordinário se amalgamavam no mesmo cenário de destruição do pós-guerra, não havia necessidade de "rebuscamento" para o tratamento 
tende "alcançar um real que existisse independentemente da imagem, mas um antes e um depois assim como coexistem com a imagem, inseparáveis da imagem"85. O quadro frontal é uma reflexão que se desenvolve ao mesmo tempo na televisão, na videoarte e no cinema, fazendo do vídeo um espaço para os trânsitos, por onde todas as mídias operam juntas e, em seguida, são devolvidas para o mundo, cada vez mais próximas e transversalizadas. As investidadas de Peter Greenaway, Francis Ford Coppola, Michelangelo Antonioni, Jean Luc Godard, Glauber Rocha, cineastas que buscaram no vídeo uma forma de reconfigurar o próprio trabalho no cinema, principalmente entre as décadas de 1970 a 1990, não são estranhas às de artistas como Vitto Acconci, Ana Mendieta, Bruce Nauman, Bill Viola, Matthew Barney e Katia Maciel, contemporâneos aos cineastas, que performaram o tempo no vídeo com a videoperformance, para além do mero registro do corpo em ação performática.

Tal cinema certamente não pode ser pensado muito distante da arte, mas intrínseco à ela. Marcel Duchamp nos faz perceber como os objetos mais inusitados podem ser preenchidos absolutamente por uma atmosfera de significados, algo que ele sempre fazia e que tornou-se a essência da arte moderna. Pega-se praticamente qualquer coisa e preenche-se com todo significado que se possa atribuir-lhe, todos os significados completamente arbitrários e pessoais possíveis, todo o mistério, todo o enigma que ela possa conter. Trata-se do início de começos incomensuráveis.

das imagens (TEIXEIRA; MARCARELLO, 2006, p. 267), "espessos e multifacetados o suficiente para desafiar e ultrapassar todo senso de ficção" (Id, Ib). As poéticas modernas voltavam-se para a confluência entre arte e revolução, para o desejo de confundir arte e vida, ética e estética, sensível e inteligível. Cineastas como Chris Marker, Clouzot e Agnès Varda ensaiaram, na década de 60, o que configurou-se como "cinema direto", em que John Cassavetes, Pierre Perrault e Jean Rouch são comumente lembrados como alguns dos principais adeptos de uma estética que pensou as formas do "direto", do "em campo", do "ao vivo", quando, além da relação ética e estética, ocorria toda uma mutação do aparato técnico.

85 DELEUZE, 2009, p. 52. 
retiro a camiseta do guarda roupas e coloco sobre a cama.

em um primeiro momento, cubro toda a camisa com fita crepe, fazendo com que ela desapareça.
CAM 1: plano médio frontal enquadra a cama e o guarda roupas. a câmera captura toda ação.

CAM 2: plano detalhe, plongée em ângulo zenital, mostra toda a ação enquadrando a camisa sobre a cama.

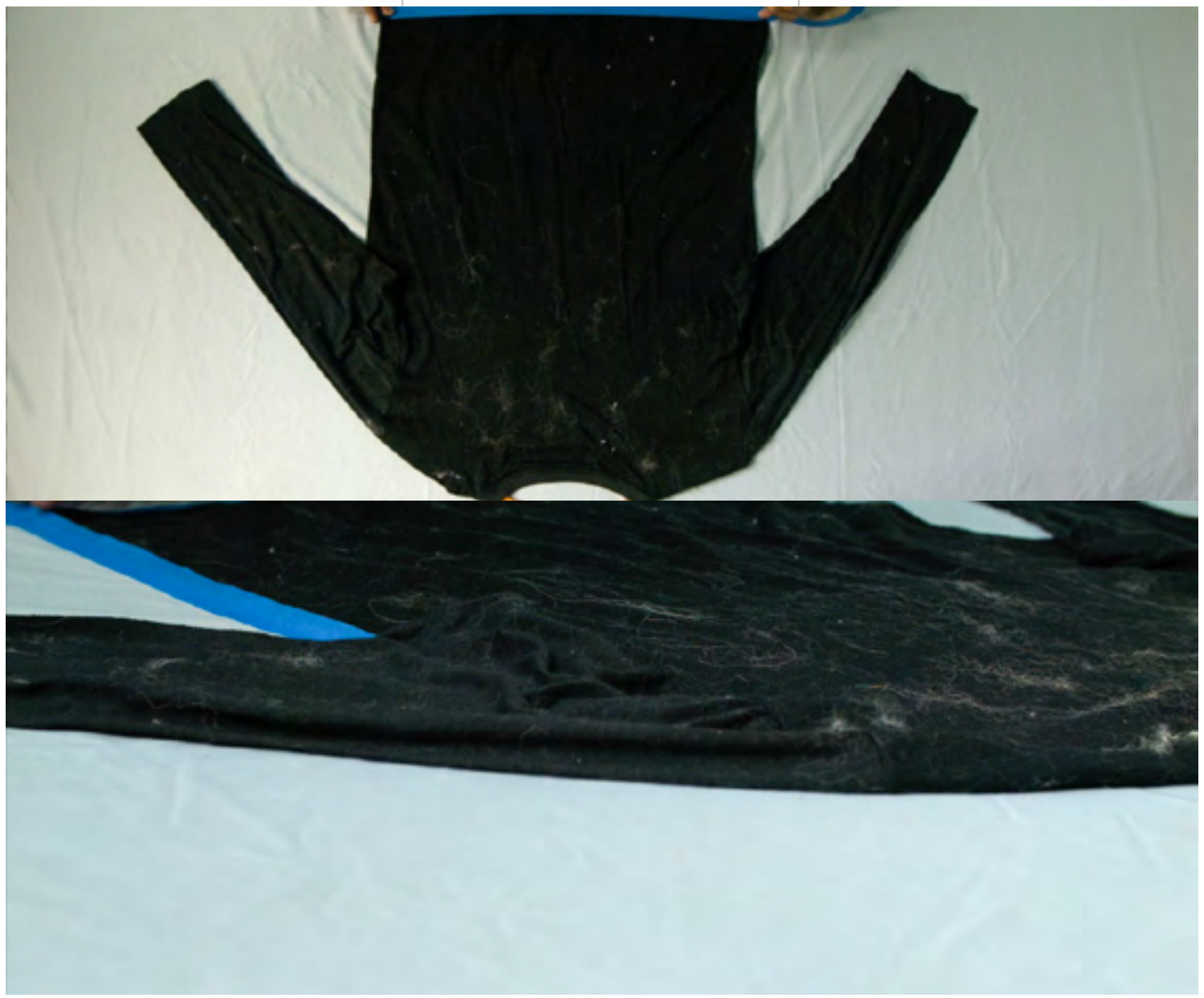

Imagens de Roupa Branca, Maurício Chades, 2015 
O ritual pode ser definido como a encenação de um mito, quando tornar ações cotidianas em ritual é tentar a experiência de uma vida mitológica "e é a partir dessa experiência que se pode aprender a viver espiritualmente" ${ }^{86}$. Permitir em vida uma encenação mitológica, uma ritualização dos eventos cotidianos, pode ser um momento de passagem, brecha para atualização do ser-aí, uma forma de ainda-viver, para permitir um ainda-estar. O rito, uma representação arquetípica, é um símbolo de uma estrutura morfológica maior do que o próprio corpo físico que põe-se a encenar, quando "atinge-se aquela dimensão que transcende a temporalidade, aquela dimensão da qual a vida provém e para a qual retorna"87.

Logo nas minha primeiras semanas residindo o Urubu ${ }^{88}$, Leni, minha gata de estimação foi encontrada morta no quintal do vizinho, que depositou o cadáver em um saco de lixo e desfez-se do peso. Nunca a vi sem saúde, machucada, nem sem vida. A perda para a morte não aconteceu, mas sim um desaparecimento de uma presença que era contínua na casa antiga e que começava a produzir as primeiras memórias de habitar a nova concha. Do desaparecimento-morte, apeguei-me aos vestígios de passagem, às marcas de uma casa compartilhada com o animal. Na ação videográfica Roupa Branca, revelo do guarda-roupas uma camiseta preta manchada por pelos brancos, um ruído evidente no tecido liso. Com uma fita crepe azul, desenho linhas sobre o corpo da camisa, pinto-a de azul e então faço o movimento reverso, removendo a fita e os pelos, devolvendo o preto profundo e homogêneo do tecido. O bolo de fita constitui um artefato morto com fitas amassadas e pelos brancos sobressalentes.

Entre o ritual de morte e a fenomenologia da imaginação, busco uma expressão que não se contente a uma redução que transforme as imagens em meios subordinados. As imagens precisam ser vividas de forma direta, como os acontecimentos súbitos da vida. Segundo Mario Perniola, o conceito de simulacro, "uma 'cópia qua copia', uma cópia enquanto cópia" ${ }^{89}$, parece servir à ideia de ritual, por tratar justamente de uma reivindicação de autonomia, quando a cópia deixa de depender do original e se liberta de toda imitação. Quando descolo os pelos brancos, rasuras na lisura do tecido preto, e os organizo em uma bola de fita crepe, faço como uma encenação, mas enquanto estou vivendo. Trata-se de uma ação a ser filmada em apenas uma única tomada: a

86 CAMPBELL, 1990, p. 192.

87 Id.

88 Em Ensaio 1: Áruore Parada relato a experiência de mudar-me para o Núcleo Rural Córrego do Urubu, evento central no desenvolvimento deste projeto.

89 PERNIOLA, 2000, P. 29. 
camisa é esta e nunca mais será preenchida por pelos de alguém que já não está aí.

A ritualidade consiste no fato de todos os gestos provirem do exterior, de fora, sejam os pertencentes à nossa herança cultural, à nossa classe social, à nossa história pessoal, sejam os pertencentes a outros povos, outras classes e outras pessoas. Na ausência de qualquer critério e de qualquer possibilidade de escolha racional, "toda ação é imotivada; cai o fundamento metafísico das ações, que eram fixadas, imobilizadas pela identidade coletiva dos costumes ou pela identidade pessoal da moralidade" ${ }^{90}$. Chega-se ao simulacro não por imitação, mas por um mimetismo vertiginoso graças ao qual o que é espúrio, derivado, replicado, se libera do autêntico, do originário, do único.

Eventos colhidos dos meus dias, da insignificância da minha biografia, fazem surgir as imagens de Roupa Branca. O ritual de morte incompleto, de um corpo virtual e desaparecido, motivam um simulacro de morte, uma cópia de enterro e uma cópia de cadáver que permitam fazer morrer o que ainda está aí. O exercício fenomenológico nos pede justamente para viver com importância as coisas insignificantes, quando se completa, por meio de devaneios, as lembranças a serem confidenciadas, entregues em uma linguagem poética. "O insignificante torna-se então o signo de uma sensibilidade extrema para significações íntimas que estabelecem uma comunhão entre a alma do artista e a do público"91. 

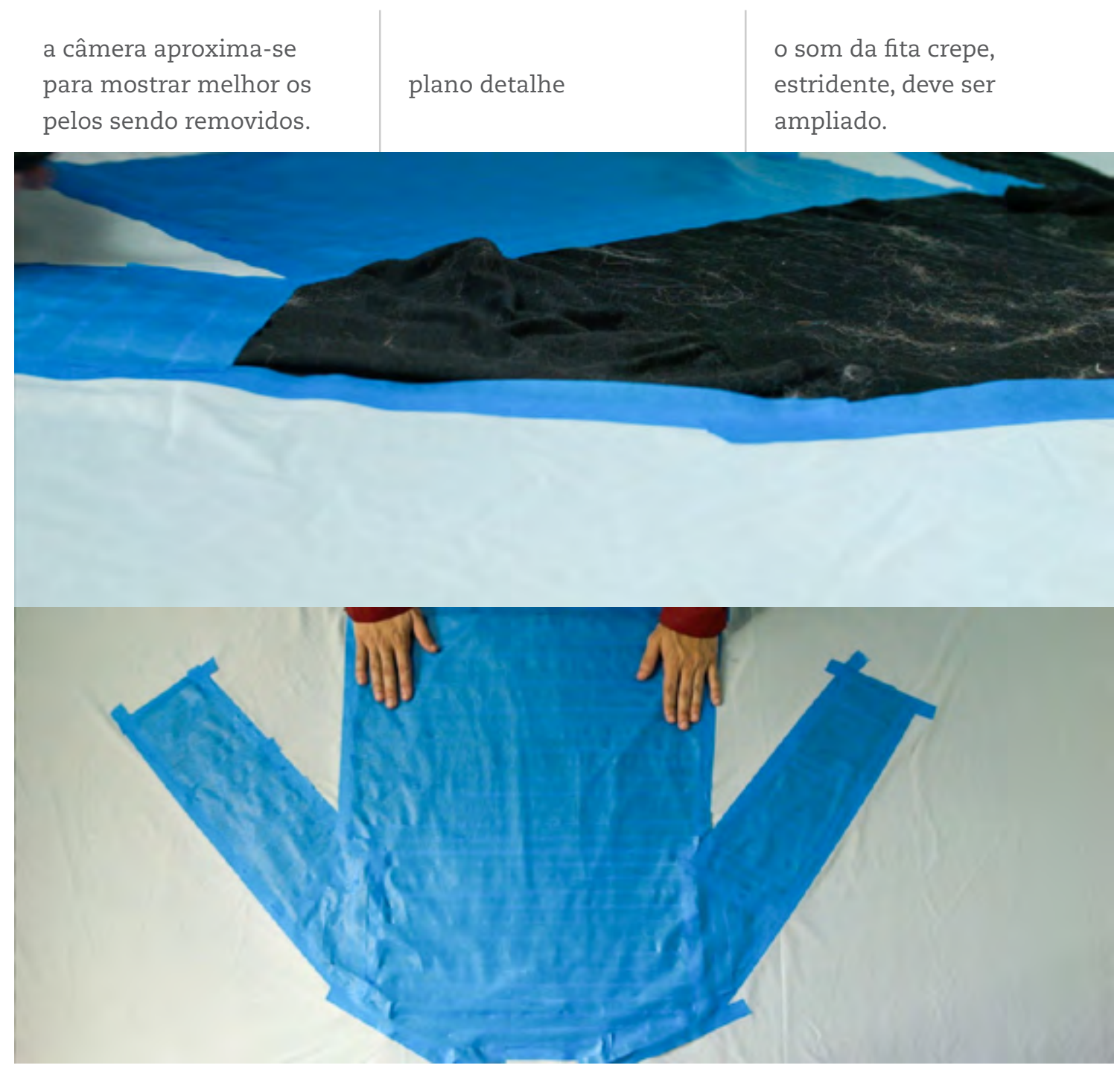

Imagens de Roupa Branca, Maurício Chades, 2015

Perniola considera "simulacros de morte" os túmulos, igrejas, palácios, instituições e obras de arte erguidos com a inanidade dos desejos humanos em tentar representar a queda das grandezas terrenas, sejam nossas experiências com a morte do corpo biológico ou mortes simbólicas, etapas de mudanças profundas. Para o autor, "as riquezas, honrarias e pompas são apreciáveis justamente porque são sentidas e vividas como sendo nada"92, mas tratam-se justamente de uma pulsão que não deveria ser recalcada, que pode retornar a qualquer momento na vida cotidiana como uma angústia de esperar pela morte, de desconhecê-la. Os canais de intercâmbio e de troca simbólica com a morte, de reconhecimento dela na vida cotidiana, devem ser estimulados para não agigantar a força de uma potência psicológica oculta e subterrânea, tanto mais obssessiva quanto menos evidente for. "Se o cemitério não existe mais, é porque as 
cidades contemporâneas assumem por inteiro a função deste: são cidades mortas e cidades de morte" ${ }^{\prime 3}$.

A angústia está estreitamente ligada à condição humana, a qual se encontra essencialmente viciada pelo pecado original. Perniola considera que ela seja o estado afetivo fundamental da vida cristã, constituindo a premissa imprescindível do processo de salvação, portanto, não trata-se de um sentimento acidental, "mas deriva da perda irremediável e definitiva da integridade original"94. Por outro lado, para Edson Luiz André de Sousa, a angústia pode nos ajudar a ver, sobretudo porque introduz a dimensão da dúvida, do "não sei", "esburaca as imagens potentes do que é claro e estabelecido" 95 . A angústia pode funcionar, portanto, como motor de novas imagens permitindo um trabalho de entendimento daquilo que vemos e que não cabe mais apenas em nossas categorias conceituais.

Tento fazer com Roupa Branca, bem como em todos os vídeos da série que organizo com esta dissertação, um canal de troca simbólica com a morte, de reconhecimento dela nos meus dias e, portanto, na vida social. São videoinstalações-lápide, um deslocamento das tradicionais representações arquitetônicas e escultóricas para uma representação com imagens fantasmagóricas projetadas e organizadas no espaço expositivos através de videoinstalações. Vídeos que surgem da necessidade de ritualizar potências recalcadas, mas entregues como imagens para o mundo, quando conhecer a minha biografia deverá ser opcional, ou pouco deverá importar, para a fruição de formas, cores, sons, movimentos e pensamentos orbitantes no espaço do quadro, enriquecido de conceitos na derme sensível da profundidade de campo.

Luminous People é a recriação de um evento para comemorar a presença da morte e as memórias deterioradas dos vivos, no cinema. O curta de Apichatpong Weerasethakul é apresentado como um segmento dentro do filme O Estado do Mundo (2004), longa comissionado pela Fundação Calouste Gulbenkian e que também recebeu criações dos diretores Ayisha Abraham, Chantal Akerman, Pedro Costa, Vicente Ferraz e Wang Bing. Um grupo de pessoas viaja pelo Rio Mekong que se estende ao longo da fronteira entre Tailândia e Laos. Uma senhora lança cinzas no meio do rio, que se misturam imediatamente à água turva. Foram recrutados moradores locais de Nong Khai, uma pequena cidade próxima ao Rio Mekong, como elenco para o filme. Após as gravações, parte do elenco assistiu ao material filmado e a conversa gravada foi incluída no filme. Um dos atores relata a experiência de ter recebido a visita de seu pai durante um sonho: "eu fiquei muito feliz, eu envolvi meus braços à sua volta, limpei-o com um pano. 
Queria tirar uma foto, corri para pegar a câmera da minha mãe, mas ele se foi. Flutuou e desapareceu". O crítico James Quandt percebe em Apichatpong "algo diferente"96 na significação da doença e da morte. Ele sugere que a relação do artista seja influenciada pela tradição budista, acostumada à impermanência e à crença na reencarnação. No filme, o barco inverte a marcha ao cruzar a ponte que liga os dois países, quando os tripulantes estão cansados, quando o filme, realizado em super-8, começa a desintegrar-se, e a fronteira passa a ter outras funções além das geográficas e políticas: ela marca a simultaneidade de dois mundos, o dos vivos e o dos mortos.

Predominam no ocidente duas visões sobre a morte, a teológica e a naturalista. Ambas tratam de formulações teóricas reproduzidas em uma atitude cotidiana extremamente difundida, que consiste em não pensar na morte, em fazer de conta que a morte não existe e em levar adiante um trabalho de constante tranquilização em relação à ela. Nos distinguimos de algumas culturas primitivas que se instituem com base em uma intensa relação de reversibilidade simbólica entre a vida e a morte. A civilização ocidental contemporânea lança um verdadeiro interdito contra a morte, excluindo-a da própria experiência. "Essa pretensão de apagar a experiência de morte está ligada à ação de acumulação e de produção material da economia capitalista"97.

A concepção teológica da morte como ingresso na eternidade fundamenta-se numa teoria metafísica do homem entendido como imagem de Deus. Da mesma forma, a concepção humanista da morte, que entende a morte como óbito (antropológico, psicológico ou biológico), fundamenta-se na teoria do homem enquanto constante permanência, enquanto simples-presença. Em contrapartida, visões como as de "Joe" antepõem-se à essas ideias, redutoras e solitárias, concepções da existência que excluem todo um ser-possível. 
após a ação, a camisa está limpa e as fitas carregam os pelos. plano próximo mostra o bolo que se formou com as fitas crepes sujas.

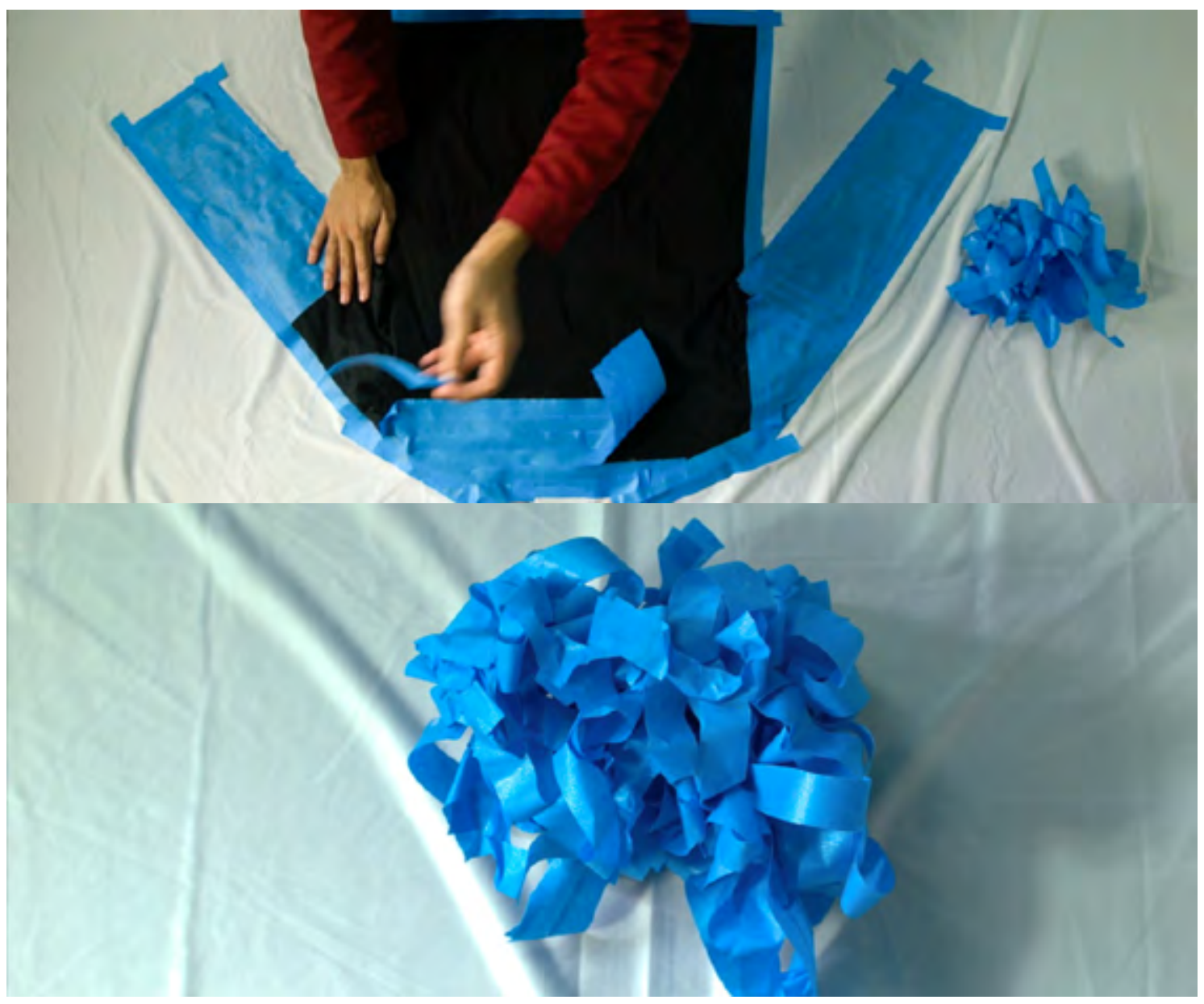

Imagens de Roupa Branca, Maurício Chades, 2015 
croqui: gabriela bílá

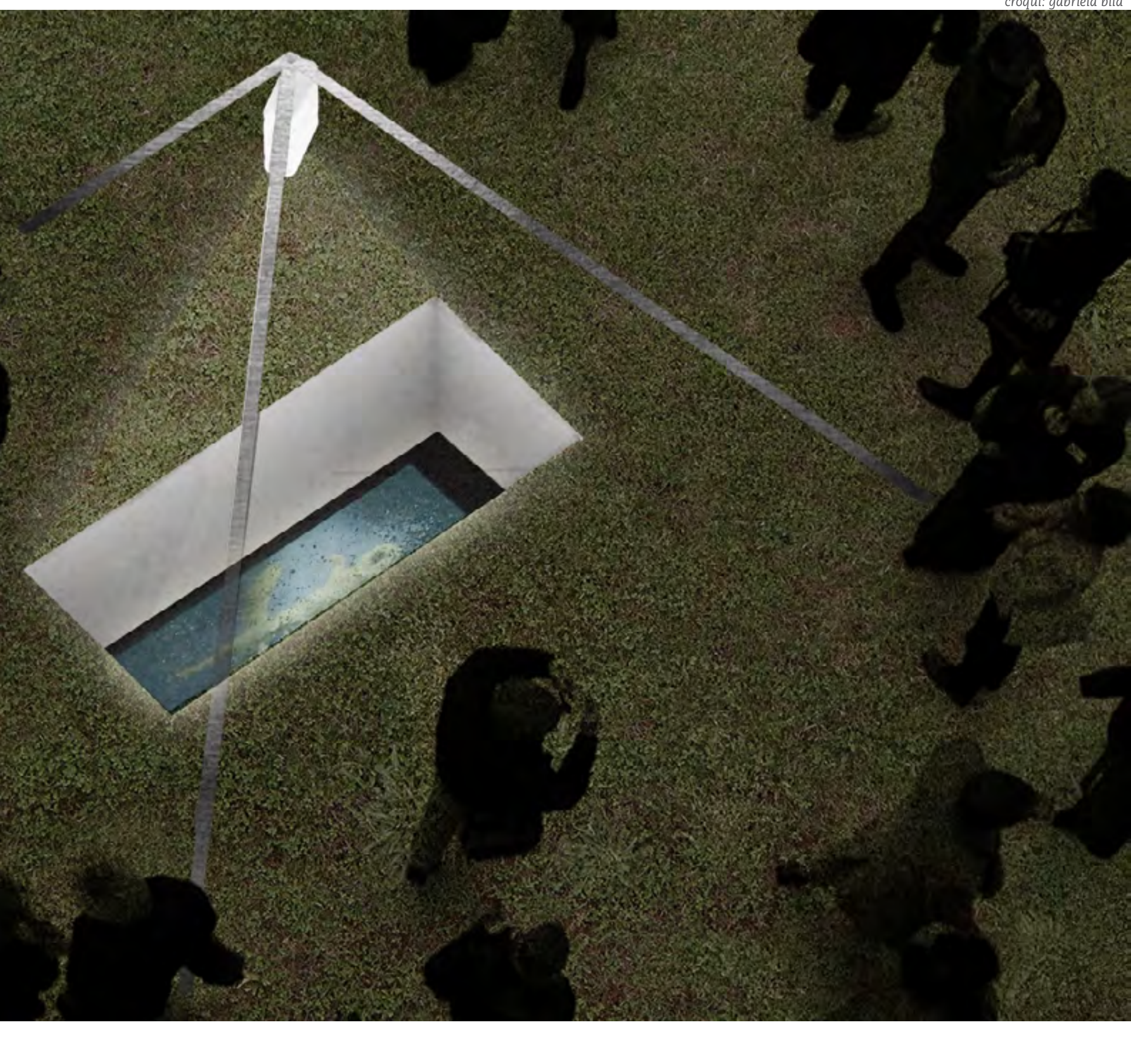

ENSAIO 3: BURACO BRANCO

vídeo: https://youtu.be/Zf2LaXbAGhQ 


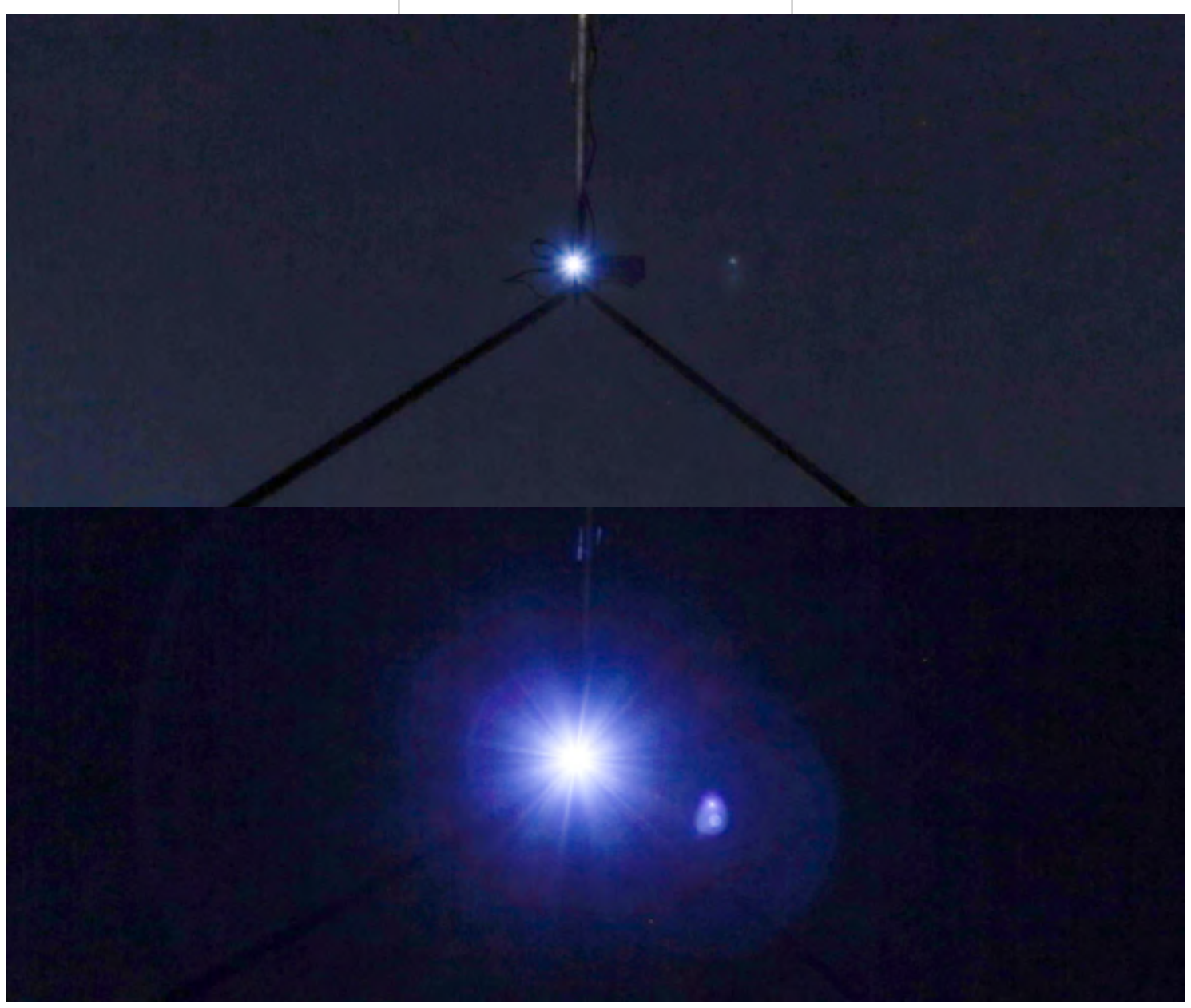

Imagens de Buraco Branco, Maurício Chades, 2016

A dificuldade de se datar quando nasce o cinema se dá justamente por que "mais do que qualquer outra mídia, surgiu aos pedaços"98. Chamamos de cinema um conjunto de características que o público pode reconhecer como um modelo de consumo, caracterizado, sobretudo, por algo que Gabriel Menotti chama de "moviegoing", ou "ir ao cinema". Dessa forma, nickelodeons e movie palaces, por exemplo, são modelos de consumo do início do século XX que, além da experiência de assistir filmes ofereciam ao espectador atrações musicais, de dança, consumação de bebidas, o próprio local dos eventos (muita vezes palácios, mansões, templos), dentre várias outras ofertas dispersivas 
em que a projeção era mais uma delas. Elementos aproveitados e descartados dessas experiências dão forma ao Multiplex, por exemplo, ou até mesmo ao site Netflix, que refletem como o cinema diminuiu a importância do contexto, tornando-se contemplativo e imersivo, para que qualquer conteúdo pudesse ser projetado em um dispositivo invisível, de arquitetura neutra. Sair de casa torna-se tão secundário que os sistemas domésticos, como adquirir home theater, televisão de alta resolução e assinar um pacote de fornecimento de filmes parecem substituir o deslocamento até o teatro do cinema. Nesse sentido, cinema deixa de ser um espaço e passar a ser os filmes.

O cinema funda-se como um meio e um modelo de consumo apropriado para ser "capaz de dar vazão e impulsionar a produção cinematográfica"99 , Sendo que a projeção de imagens, sua inscrição em película e mesmo a exploração comercial são "pedaços" mais antigos. Repensar o dispositivo, torná-lo evidente e reinventá-lo são questões afins para alguns artistas visuais e apesar de "cinema de exposição" colocar "cinema" na frente, o gênero trata de um conjunto de trabalhos afeitos às flutuações multimidiáticas, mas que não se alinham facilmente ao cinema, cujas regras de consumo são rígidas e pouco flexíveis. Quando se erguem objetos, cenografia de telas e implica-se o "espectador em relações ao mesmo tempo perceptivas, físicas e ativas, abrangendo portanto muito mais do que aquilo que as telas mostram"100, quando a imagem não pode ser desvinculada do dispositivo para o qual foi concebida, não costumamos chamar de cinema, mas de outra coisa. Assim, a história do cinema parece recalcar tudo o que foge do seu cânone. Seletiva, deixou "de fora toda uma gama de experiências realizadas por artistas e visionários, em situações e meios diversos, desde os primeiros dispositivos óticos de produção da imagem em movimento, no início do século XIX, até os nossos dias"101.

O cinema de exposição designa um conjunto de propostas que questionam o "modelo cinema" subvertendo o ritual tradicional de recepção do filme (sala escura, espectador sentado na poltrona, duração padrão imposta etc.). A tela torna-se múltipla, desdobrada, triplicada, oblíqua, põe-se o filme em cadeia de loop, o público entra e sai, passa e permanece o tempo que quer. "Experimentam-se novas posturas dos espectadores (de pé, sentado, deitado, móvel), explora-se a duração da projeção (breve, muito breve, muito longa, infinita)"102. De certa forma, o cinema de exposição pode ser considerado uma modalidade cinefágica da videoarte, que se volta para o cinema citando seus códigos, sons, imagens e "não querendo e não podendo se tornar cineclasta, o vídeo (que já fora teleclasta) torna-se cinefágio"103.

99 Id, p. 16.

100 MACHADO; DUBOIS, 2011, P. 13.

101 PARENTE, 2013, 36.

102 DUBOIS, 2011, p. 28.

103 IDEM, p. 233. 
A imagem sensório-motora, do encadeamento lógico, construída entre cortes invisíveis na montagem, plano a plano, na linha do tempo como a imagem-movimento que "não reproduz um mundo, mas constitui um mundo autônomo, feito de rupturas e desproporções, privado de todos os seus centros" ${ }^{104}$ parece deslocada nesse outro tipo de cinema, em que o espectador passa a ser o centro de sua própria percepção, dispersando-se em andar pelo espaço e criar sua própria relação motora de montar imagens, olhando para as projeções e desviando o olhar para o que está em volta. Em uma "exposição de cinema" a continuidade das imagens projetadas é interrompida pelo deslocamento aleatório do visitante-espectador, dificultando qualquer pretensão de significado possível apenas para espectadores imóveis. O espectador, não cativo em uma poltrona, não busca pela complexidade dramatúrgica que dificilmente se realiza quando o corpo está em movimento: "mais do que o significado, busca-se a sensação; a sensorialidade contra o sentido"105.

A condição de descoberta dessas obras é o deslocamento do corpo do espectador, um fruidor-participante. No cinema, parece mesmo que a caixa preta reveste os componentes do dispositivo: caixas de som e projetor estão escondidos, o que dificulta seu estudo. Nada mais prático que retirar tela e os demais componentes da caverna para serem observados e, então, remodelados. 
uma tela branca está instalada no fundo de um buraco. quando a imagem projetada se revela, à medida que a lâmpada do projetor esquenta, vemos um gato. começo a jogar carvão triturado sobre a projeção, diminuindo a reflexão da luz. em plongée (zenital), o buraco delimita as bordas do quadro. o som do carvão sobre

a tela é evidente no

ambiente silencioso.

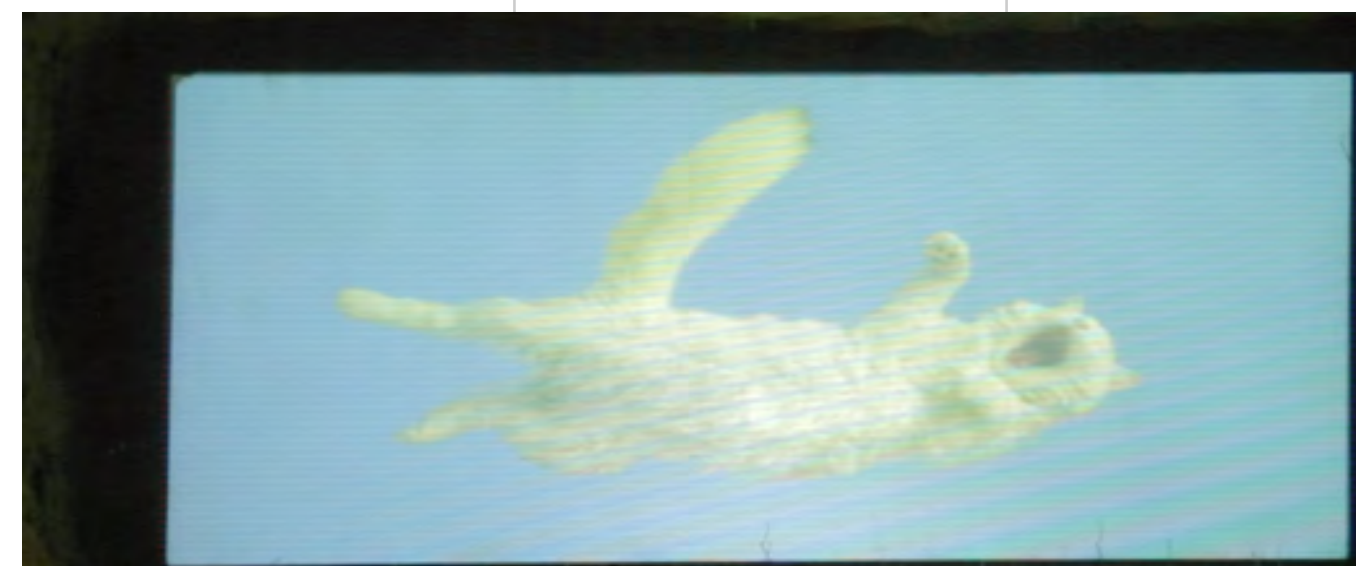


A projeção de imagens é mais um material utilizado por artistas, mas que "oferece uma imaterialidade tremendamente atraente: a imagem projetada está lá e não está" ${ }^{106}$. Desde a sala de cinema já se tensionam a representação (transparência) e a presença (opacidade), mesmo que no dualismo quase invisível entre as projeções na tela e o público inerte, adormecido nas poltronas. Comparar a densidade das presenças, das mais opacas às mais transparentes, pode criar uma investigação sobre o deslizamento das imagens em dois mundos, entre um mais sutil e um menos evidente.

Em Buraco Branco, projeto uma foto da gata Leni em uma tela branca no fundo de um buraco, cuja proporção é 2,35:1, o chamado formato anamórfico, comum às salas do Multiplex. Em uma tentativa de apagar e enterrar a projeção, pinto o quadro jogando areia preta, que retém para si boa parte da luz, apagando a aparição do corpo do felino. Ao tensionar terra/luz, tento incorporar na obra o tempo, me rementendo a algo que acontece e está acontecendo, a causa e efeito, em uma relação mesma de performance, "esse outro meio das artes visuais contemporâneas que introduz o temporal dentro da materialidade do objeto no âmbito visual"107. Aqui, o projetor não está escondido, mais que isso, ele é evidenciado, ,suportado por três pernas de ferro, no topo de uma pirâmide, constituindo assim, com o buraco, um circuito de filmagem/projeção, aparição/túmulo. O vídeo é devolvido para o buraco durante a exposição do trabalho, de forma que o buraco seja cavado mais uma vez.

Imagem virtual (projeção) e real (areia) interagem, atualizando-se mutualmente, possibilitando outros modos de existirem. Areia recebe projeção e torna-se virtual, enquanto a projeção recebe areia e torna-se real, ou seja, "o virtual é um 'real' que se manifesta naquele momento. O real como atualização de um dado que está escondido no sistema pronto para se fazer presente." ${ }^{108}$. Podemos entender o circuito buraco-tela/ pirâmide-projetor como uma máquina que deixa de reproduzir uma foto de uma gata para gerar seu próprio real, sendo esta a própria imagem da videoinstalação, quando pouco importa representação nem referente. Em termos mais precisos "não é mais a imagem que imita o mundo, é o 'real' que passa a se assemelhar à imagem"109, quando a mímese funciona como dois espelhos paralelos que se repercutem ao infinito sem que saibamos qual foi o ponto de partida. 
Ao longo da história da humanidade, culturas primitivas ergueram túmulos em diferentes formatos, desde grandes monumentos a homenagens mais discretas. Devolver o cadáver a uma ordem metafísica do mundo se repete em diversos povos como uma característica recorrente. Erguendo as pirâmides do Egito Antigo, o Taj Mahal, recorre-se a construções, a densidade de materiais pesados, para dignificar algo que foge à materialidade como a conhecemos. $\mathrm{O}$ arquiteto paraguaio Solano Benitez também faz uso de materiais pesados na construção de Túmulo para seu pai, mas opta por elementos menos densos para evocar uma sobreposição de memórias e lembranças que marcam a passagem do ente querido. Quatro paredes foram erguidas no quintal da família, apoiadas cada uma em um único ponto e revestidas internamente com espelhos. Ao deslocar-se no interior da instalação, o espectador tem a experiência de, em determinadas posições, perder de vista os muros que refletem por completo a vegetação verde do jardim. Os registros do trabalho em fotografia e vídeo não parecem conseguir captar a experiência possível quando coloca-se o corpo inteiro na obra.

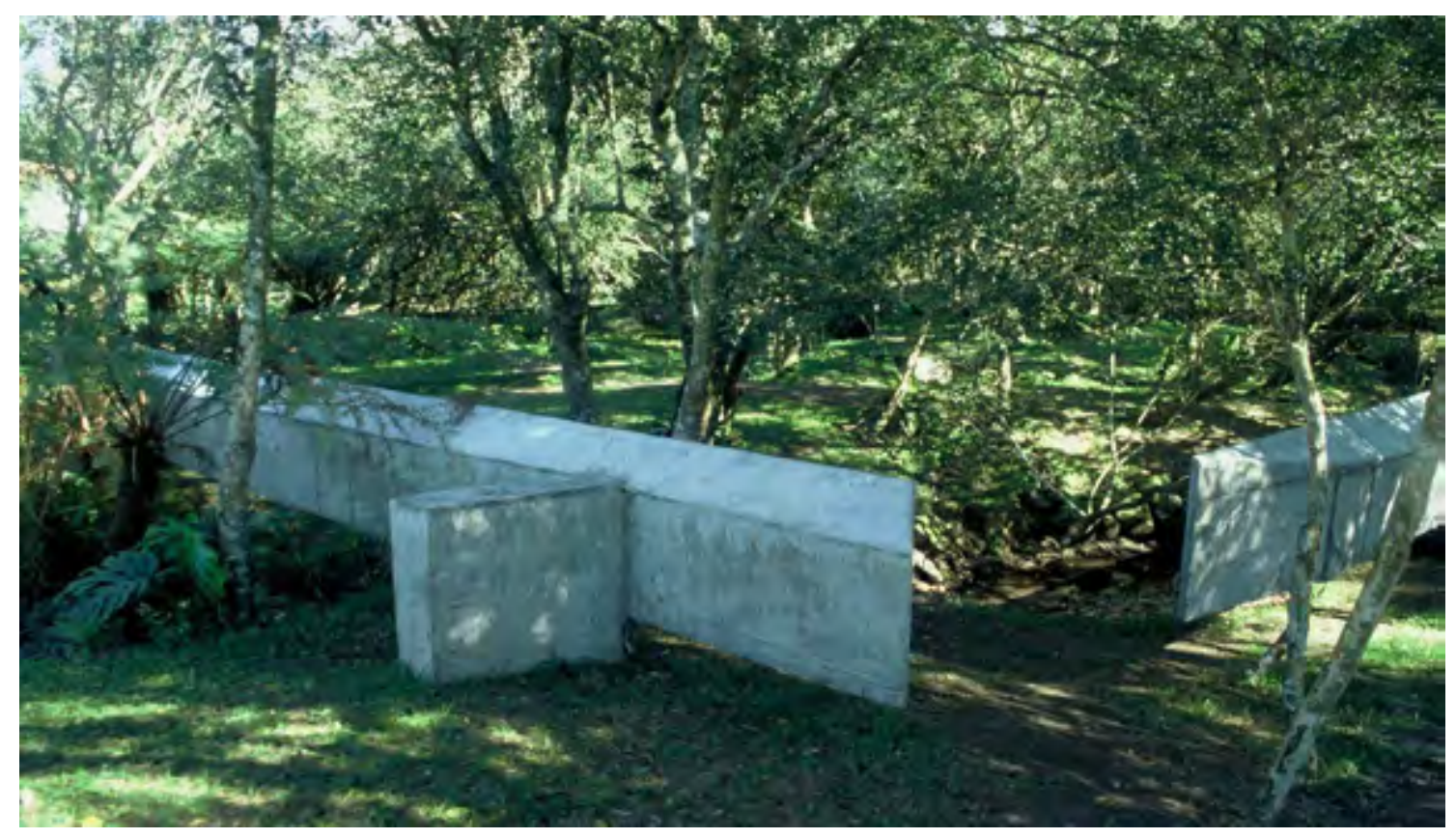

Túmulo, Solano Benítez, 2011

Para André Parente, a imagem-tempo cria um circuito de indiscernibilidade entre o real e o virtual. O virtual não se opõe ao real, mas sim aos ideais de verdade "que são a mais pura ficção"110. Deleuze define como "imagem-cristal" o menor curto-circuito entre a imagem atual e sua própria imagem virtual, quando acontece, entre elas, uma coalescência. A percepção do tempo desdobra-se em uma imagem bifacial: a percepção do presente (atual) e a memória do passado (virtual). 
As obras de Apichatpong Weerasethakul muitas vezes parecem produzir tal imagem coalescente quando não anunciam passado, presente e futuro, nos colocando para olhar através de um cristal de onde percebemos os tempos todos sobrepostos em uma Tailândia tradicional/tecnológica, urbana/rural, viva/morta. Mal dos Trópicos, por exemplo, é dividido em duas partes, quando, a partir da segunda metade do filme, os mesmos atores parecem despertar de um sonho, ou passam a sonhar, e começam a viver outras vidas, encarnados, isto é, "a pausa no meio do filme é um espelho no centro que reflete ambos os lados"111.

Em Cemitério do Esplendor, soldados sofrem de misteriosa doença do sono e são transferidos para uma clínica. Jen, uma volutária, faz amizade com Keng, médium que coloca os soldados em contato com membros da família. Durante as investigações sobre o sono dos soldados, percebemos que é a própria Jen que viaja para dentro de si mesma e para temporalidades contidas nos espaços ancestrais que visita com Keng, em uma busca pelaconsciência profunda de si mesma e do mundo ao seu redor.

O plano dos espíritos parece um lugar cotidiano não só para Joe, mas para a cultura tailandesa que vê constantemente os espaços sagrados se empilharem entre as novidades trazidas pela globalização. Modernos prédios se erguem e luminosos painéis eletrônicos ocupam metrópoles tailandesas, como a capital Bangkok, mas não se apaga das cidades algo invisível e que flutua sobre as edificações, que personagens dos filmes de Joe parecem perceber alí um contínuo estado de presença, para onde pode-se ir e vir, consultar e continuar, em uma relação de acesso tranquilo. "O filme é uma busca por espíritos antigos que conheci na infância"112, afirma Apichatpong que parece ter uma relação de tranquilidade convivendo entre dois mundos, ou em um mundo em que a reversibilidade entre vivo/morto é mais sutil. Joe se refere à infância, quando acompanhou os pais médicos no hospital que ambienta cenas do filme.

Tenta-se cromoterapia no tratamento experimental dos soldados e, em determinada sequência, o filme nos mostra vários espaços da cidade coloridos com as mesmas luzes do hospital: um outdoor que faz propaganda de serviços cerimonial, um shopping center, uma cidade inteira contagiada com a doença do sono. Se as relações de consumo impostas pelo capitalismo tentam afastar a morte da vida cotidiana, é de uma Tailândia em contrafluxo que nos fala Apichatpong? "Se o cemitério não existe mais, é porque as cidades modernas assumem por inteiro a função deste: são cidades mortas e cidades de morte" ${ }^{113}$.

A morte, para Joe, não trata de uma relação de perda do corpo biológico, mas de cons- 
tante presença, quando vive-se a tranquilidade de estar em um tempo espesso, em quecamadas são sobrepostas de tal forma que já não faz sentido tentar reagrupá-las para serem lidas em uma linha do tempo, uma imagem sesório-motora, mais comumente praticada pelo pensamento ocidental, que costuma ver a morte como aquele evento que nos separa de estar vivos.

A imagem-tempo nos leva a uma indeterminabilidade e indiscernibilidade geral, quando não se sabe, e pouco importa, distinguir subjetivo de objeto, imaginário de real, físico de mental. "É como se o real e o imaginário corressem um atrás do outro, se refletissem um no outro, em torno de um ponto de indiscernibilidade"114.

O presente muda ou passa, sendo esta a condição da imagem atual, em (ir)reversão com a virtualidade. Quando já não é, o presente torna-se passado, quando outro presente o substitui, uma nova atualidade. É preciso que o tempo se desdobre a cada instante em presente e passado, ou que desdobre o presente em duas direções heterogêneas, uma se lançando em direção do futuro e outra caindo no passado, sendo esta operação fundamental do tempo o que constitui a imagem-cristal. "A imagem cristal não é o tempo, mas vemos o tempo no cristal"115. O que se vê no cristal é o tempo em seu duplo movimento de fazer passar os presentes, de substituir um deles por outro no rumo do futuro, mas também de conservar todo o passado, de fazê-lo cair numa obscura profundidade.

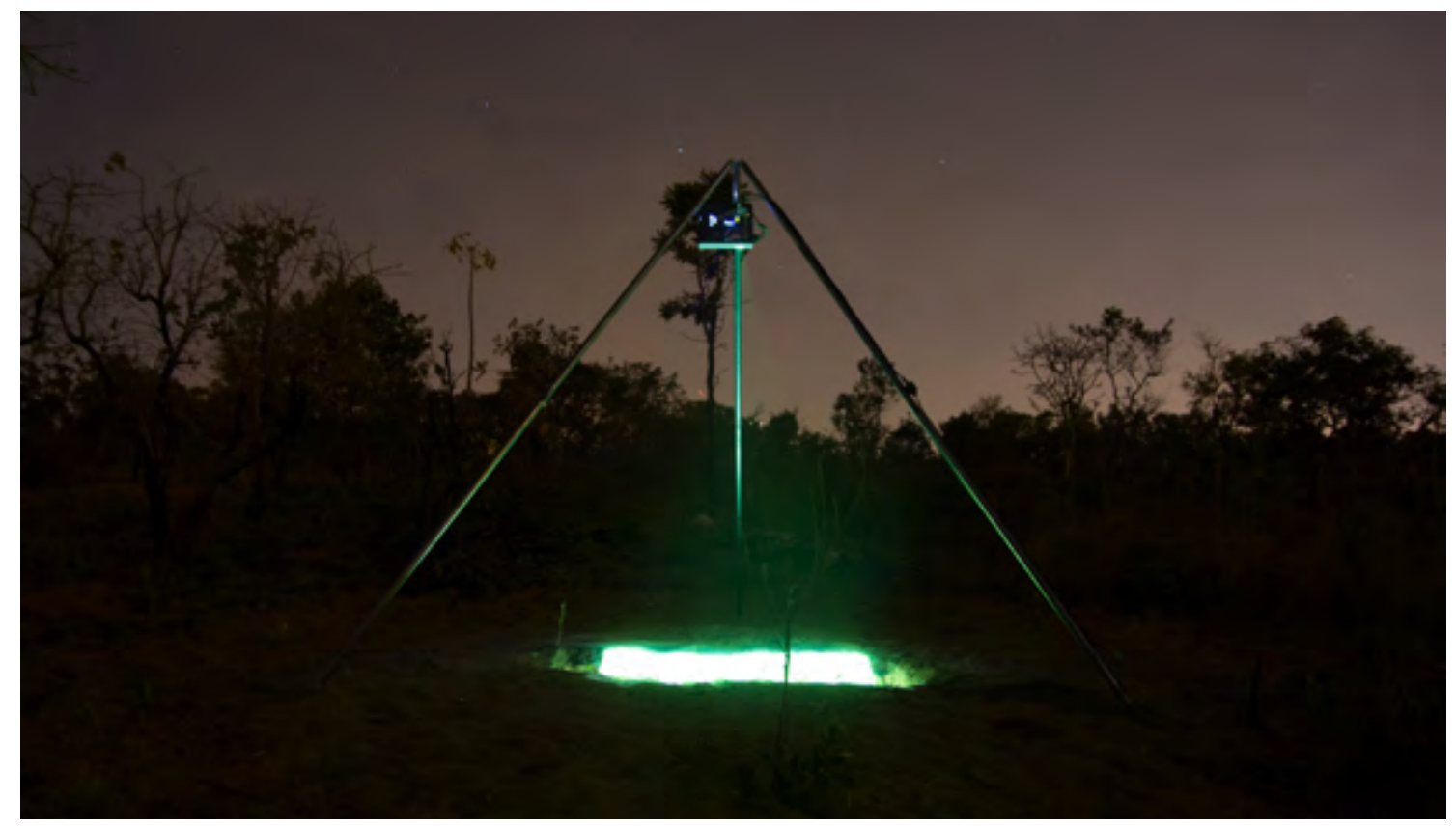

Videoinstalação Buraco Branco, Maurício Chades, 2016 (foto: Flora Egécia)

114 DELEUZE, 2009, p. 16.

115 Id, p. 102. 


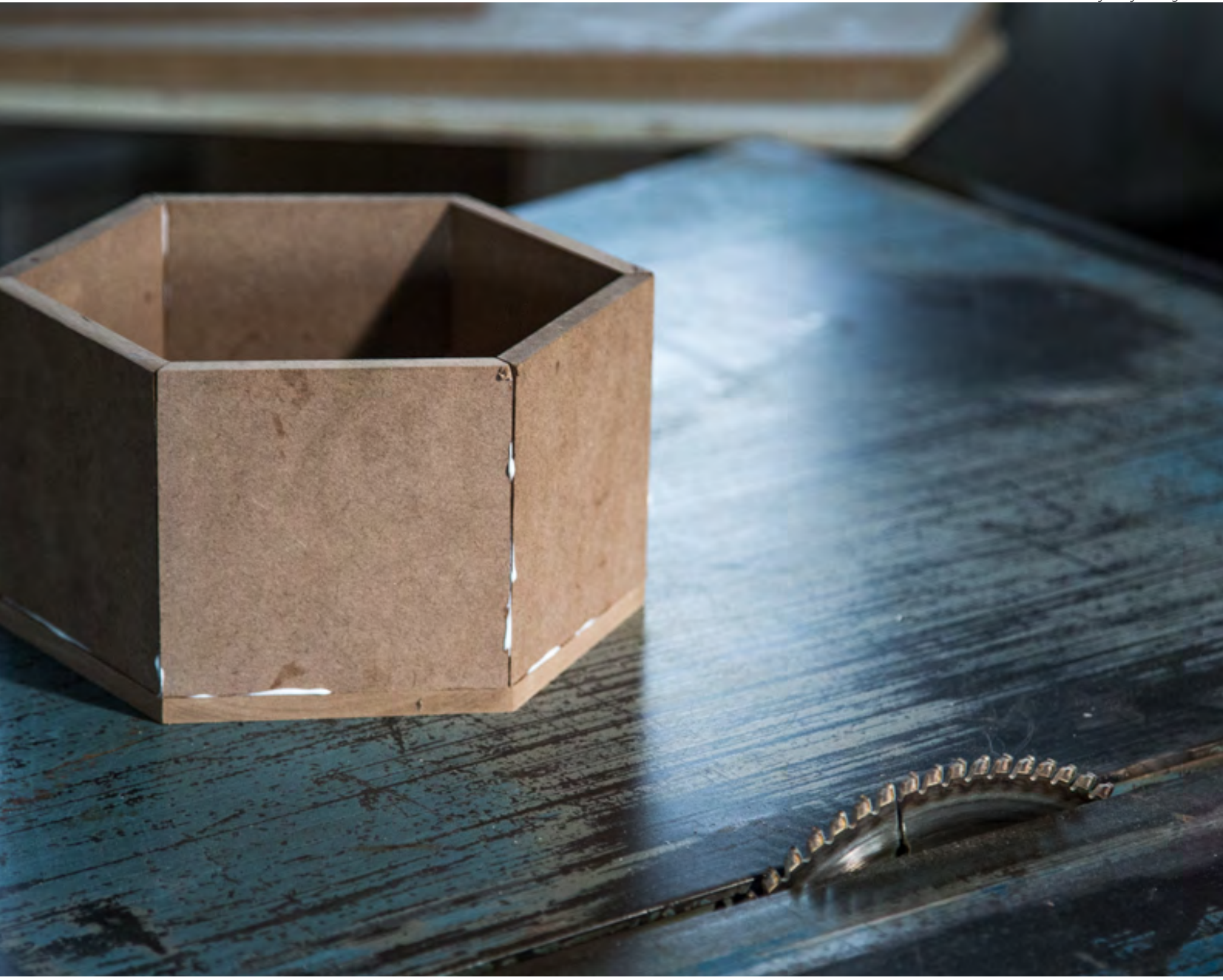

ENSAIO 4: CAIXÃO, CONTINENTE ${ }^{116}$

\section{vídeo: https://youtu.be/KyPArm4laOM}

116 Ensaio livremente inspirado em textos de O que vemos, O que nos olha, Georges Didi-Huberman. Me reservei de fazer haspas ao longo do texto para não interromper um fluxo entre as frases do autor e as minhas. 
um pedaço quadrado de MDF está sobre uma mesa de corte. com uma régua, marco linhas em lápis de cor azul, ligando pontos. formam-se quadrados e hexágonos. no mesmo quadro, em planosequência, as peças são cortadas. o som do lápis é

ensurdecedor e, em

seguida, é substituído pelo

som da serra.

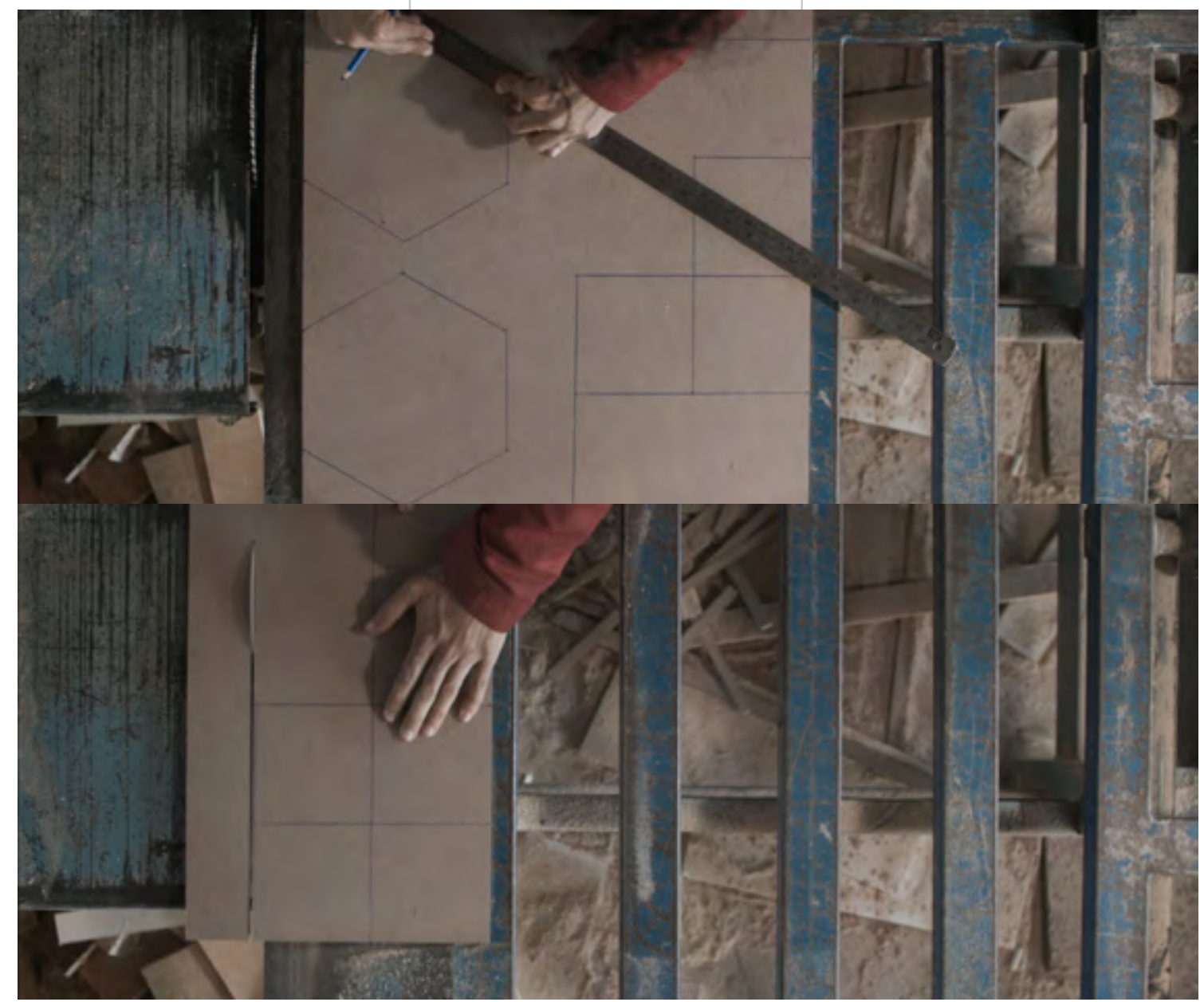

Imagens de Caixão, Continente, Maurício Chades, 2016

O que vejo do caixão, seus componentes, suas faces, paredes, anunciam o volume. A massa de madeira, um prisma gemoétrico, hexagonal, mais ou menos figurativa, mais ou menos coberta de inscrições. De dentro do espaço que se forma, algo me olha, algo pouco evidente e esvaziado. Um esvaziamento que não concerne mais ao mundo das aparências ou do simulacro, um esvaziamento que aí, diante de mim, diz respeito ao inevitável por excelência: o destino do corpo semelhante ao meu, já sem vida bioló- 
gica, sem fala audível, de movimentos invisíveis ou inexistentes, esvaziado de seu poder de levantar os olhos para mim. E que no entanto me olha em um certo sentido, direto, um contraplano perfeito, um diálogo em uníssimo, um corpo que olha e fala ao mesmo tempo, um espelho de um futuro já demarcado.

Quando vejo o túmulo, ele me olha até o âmago porque me mostra que perdi o corpo alí recolhido, colocado quase que sob medida. De que forma pode-se espalhar melhor por esses ângulos? Quem será morto e geométrico? O túmulo continua olhando, mostrando mais ainda, revelando a imagem à qual me tornarei semelhante. Quando trato das mortes de quem me é próximo, em vídeo, em escultura, em desenho, estou ensaiando sobre a minha própria? Vejo o tempo no túmulo, uma vidência de uma morte/vida já vividas. Assim, diante da tumba, eu mesmo tombo, caindo na angústia, esse modo fundamental do sentimento de toda situação, essa revelação privilegiada do ser-aí. A angústia é o olhar fundo, uma forma boa para se olhar para o buraco.

De que forma meu corpo pode ver e se oferecer ao vazio, ao espaço demarcado pelas faces, paredes da tumba? Quero mesmo lançar-me em confeccionar o caixão, em saber como se faz, para ter um e deixá-lo disponível.

Olho para o objeto e quero ver mesmo só um paralelepípedo. De trato simples do material, 6 faces laterais, fundo e tampa, sem ornamentos, MDF sem verniz, sem tinta, de onde vêm todas as outras informações? De onde invoca-se as imagens invisíveis? É um prisma e nada mais. Não é. É um caixão. A memória e o tempo metamorfoseam o objeto, como uma obsessão no olhar. A forma geométrica parece não ser árida o suficiente para conter imagem nenhuma, pelo contrário, parece ser um continente onde cabe muita coisa. O volume aí indica ele mesmo e tudo com que pode ser preenchido. 
eu organizo, prego e colo as peças. plano médio mostra toda ação.

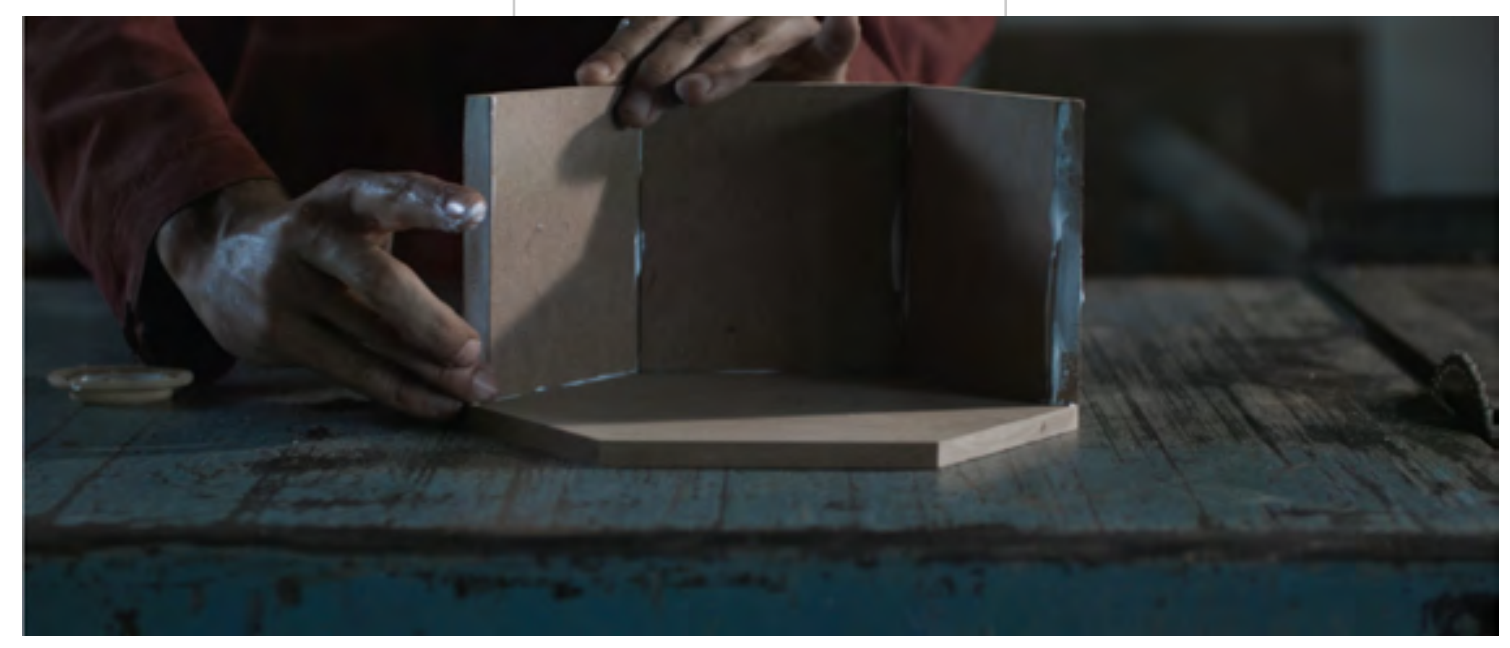

por fim, a tampa é colocada, ocultando o lado de dentro

plongée (zenital).

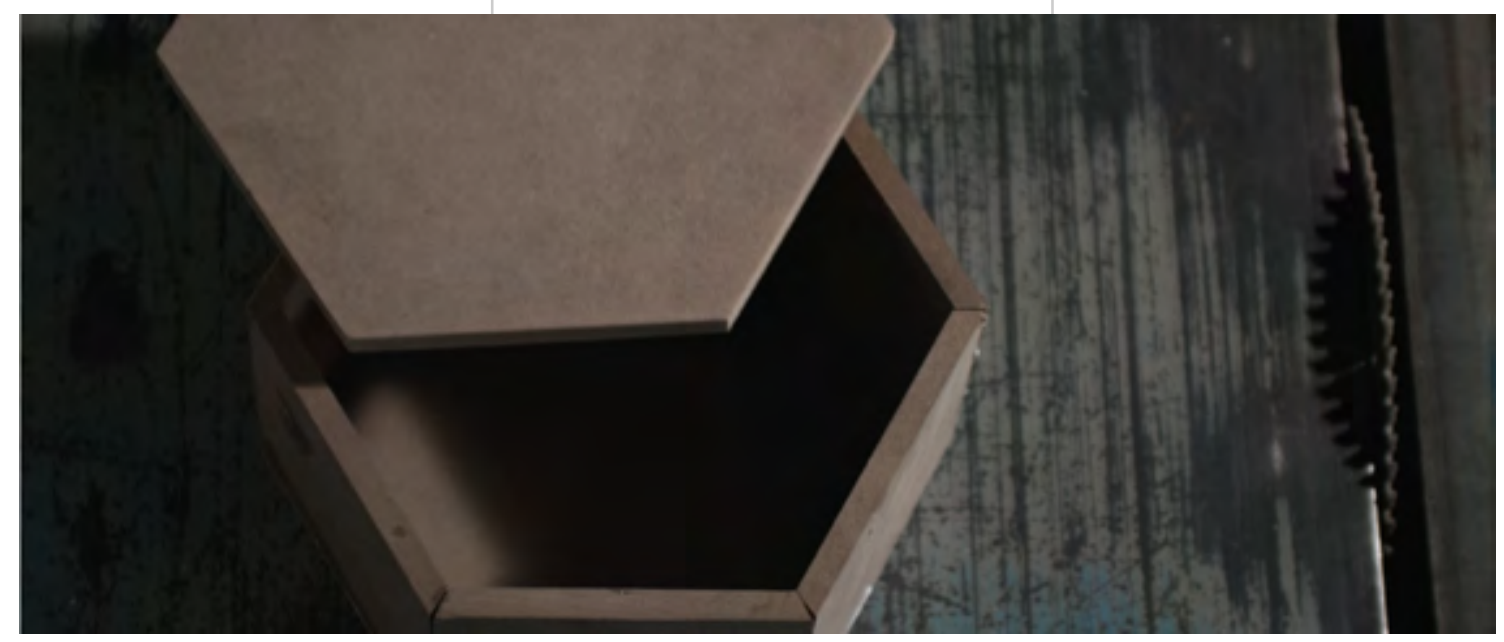

Imagens de Caixão, Continente, Maurício Chades, 2016 


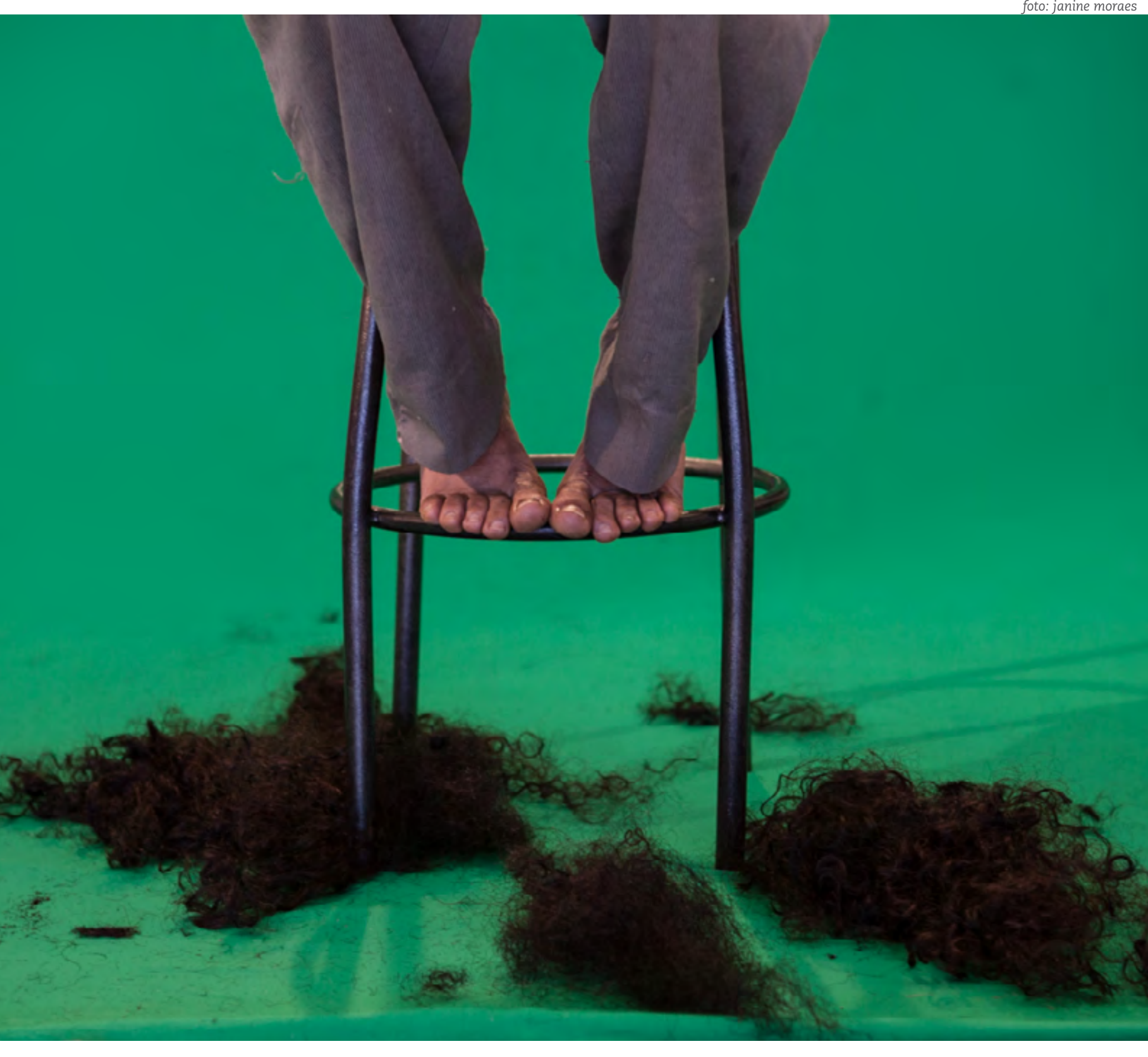

ENSAIO 5: NUNCA VI MEU PAI SEM BIGODE 


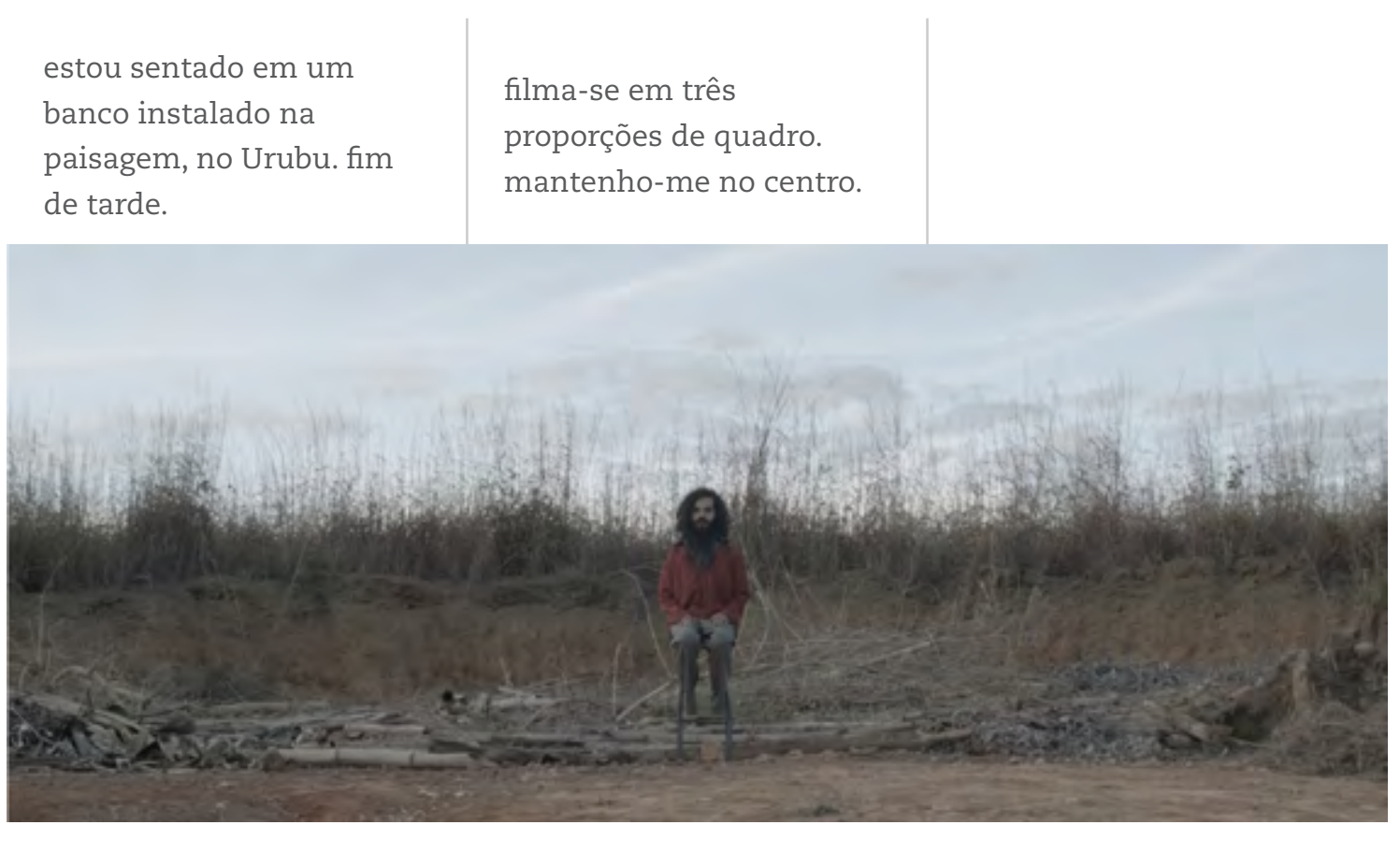

Imagem de Nunca vi meu pai sem bigode, Maurício Chades, 2016

A teleclastia praticada por artistas durante o século XX tem muito a nos dizer sobre as remixagens praticadas por VJ's nas projeções em festas. "Destruir o aparelho de TV, atacar a instituição, denunciar o dispositivo, manipular os programas, desviar o fluxo eletrônico, triturar a própria imagem"117 são atitudes de uma geração de videoartistas que ecoam como referência direta no trabalho de VJs, que fazem confluir nas projeções corpos e espaços de origens diferentes, deformando órgãos. Dubois nos fala que a partir de certo momento do século XX, a teleclastia já não faz tanto sentido para o videasta e que é preciso deslocar essa relação, pois toda imagem eletrônica já sofre de um devir-televisão ${ }^{118}$.

Os ecos da teleclastia na pista de dança datam desde a origem da videoarte. Nam June Paik, durante a década de 1960, estudava música eletrônica com Stockhausen em Colônia e teve a ideia de reverter os circuitos de um aparelho de TV, perturbando a constituição da imagem. Arlindo Machado aponta que nesse evento Paik forneceu a "linha diretriz de todo o posterior desenvolvimento da arte do vídeo, como também provocava uma reversão no sistema de expectativas figurativas do mundo da imagem 
técnica"119. A videoarte parecia perseguir uma tendência, a partir daí, de "distorcer e desintegrar a velha imagem do sistema figurativo"120, o que é praticado até hoje pelos VJs, que organizam as imagens que colhem dos filmes, do youtube, de arquivos, em loops e as recombinam, transformando-as, às vezes até tornando-as irreconhecíveis, sem relação indicial com sua fonte de origem.

Paik é um dos fundadores do Vjing. Ele, em 1969, com a ajuda do engenheiro eletrônico Suya Abe, contrói um dos primeiros sintetizadores para vídeo que, além de ser capaz de distorcer a imagem da televisão, também produzia imagens inéditas que não provinham de concurso anterior de uma câmera - eram imagens nascidas de sistemas eletrônicos. Os sintetizadores parecem querer ocupar uma possibilidade real ante o uso da câmera como captadora de imagens do mundo. Mesmo que remixem as imagens filmadas, apagar os índices e, consequentemente, as tentativas de se produzir imagens naturais, é tentador. “Temos olhos - conseguimos, realmente, enxergar sem treino?" 121 nos pergunta Peter Greenaway em uma palestra sobre o futuro do cinema.

Na mesma palestra, Greenaway afirma que "o cinema morreu no dia 31 de setembro de 1983, quando o controle remoto passou a ser parte integrante das salas de estar no mundo todo"122. Apesar do tom apocalíptico da fala, o cineasta na verdade ensaiava sobre a aderência do cinema às mídias interativas e, nesse pacto, se reinventa. Nesse sentido, Greenaway lança o ambicioso projeto The Tulse Luper Suitcases, um múltiplo que engloba três longas-metragens, uma série de TV, 92 DVDs, livros, CD-ROMs, websites e performances de Vjing em que o próprio diretor recombina o filme em suas possibilidades de edição. A história do arqueólogo Tulse Luper é contada a partir de suas 92 malas, que conteriam as diversas coleções que o personagem acumulou ao longo da vida.

Para Greenaway, "a arte do cinema teve de aprender a conviver e agir como parceira em um mundo totalmente novo de atividades multimídia - o que intrinsecamente provocou uma metamorfose no próprio cinema" ${ }^{23}$. Para "sobreviver", ele afirma, o cinema deve fazer um pacto e se relacionar com os novos conceitos de interatividade, além de abrir mão de sua centralidade nas artes do espetáculo e se considerar apenas uma parte da aventura cultural multimídia. "The Tulse Luper" trata de um projeto em que o cinema da edição, da narrativa, do enredo cronológico e do ilusionismo é deixado em segundo plano, para proporcionar uma experiência dispersiva e usar técnicas que tornaram Greenaway "um prototípico representante do que Lev Manovich chama 
de cinema de banco de dados - a promessa de uma outra linguagem cinematográfica que as 'novas mídias' estariam destinadas a cumprir "124. Cada mala pode ser pensada como uma pasta cheia de arquivos a serem acessados através das diversas interfaces, para além da forma fechada do longa-metragem. O espectador-usuário pode conhecer a vida de Tulse Luper sob diferentes óticas ao navegar nos DVDs, ver os filmes ou assistir às apresentações de VJ.

Em The Moab Story, o primeiro dos três longas-metragens, acompanha-se Tulse durante a Primeira Guerra Mundial em Utah e mais velho como um escritor na Bélgica, durante a ascenção do nazismo. Os diversos deslocamentos geográficos sugerem um estudo histórico do século 20, ao mesmo tempo em que investigamos o conteúdo das malas de Tulse Luper. A composição de quadros dentro do quadro, recurso praticado por Greenaway já em trabalhos mais antigos, é utilizada aqui para sugerir os deslocamentos espaciais e o efeito é o de empilhamento entre fundo, paisagem, e superfície, corpos das personagens. Em determinada cena, por exemplo, Tulse aparece no primeiro plano da imagem, enquanto no fundo temos um mapa digital e tridimensional em movimento, mostrando seu deslocamento entre cidades, países, como uma malha a ser percorrida e navegada. 


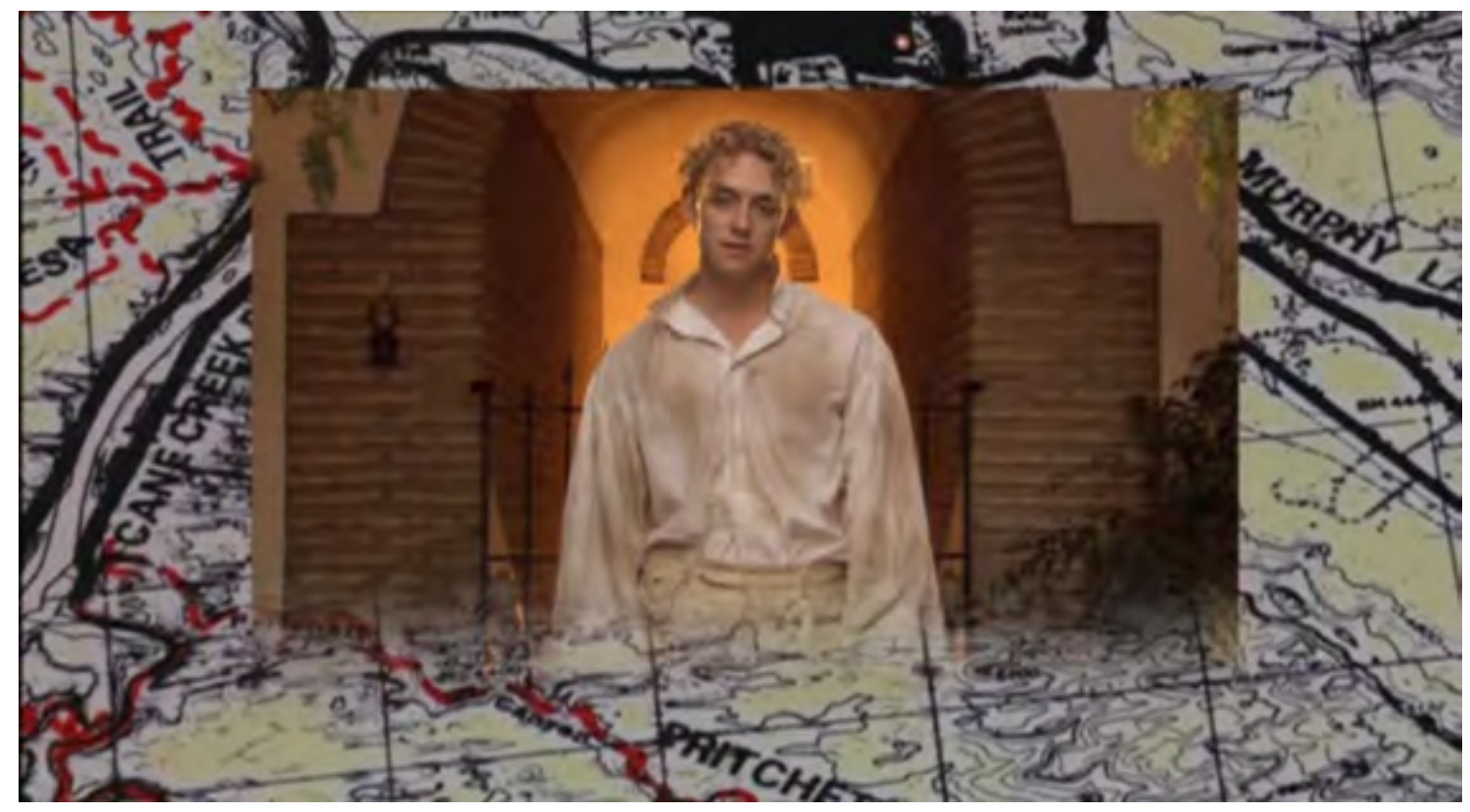

The Tulse Luper Suitcases, Part 1: The Moab Story, Peter Greenaway, 2003

Para Gabriel Menotti, a projeção do filme como uma apresentação de VJ faz com que sua composição seja radicalmente distinta, não se tratando mais de projeção de registros indiciais, mas de efetiva criação de som-imagem a partir de códigos arbitrários, por meio de processamento algorítmico em tempo real: "conforme a tela de cinema passa a ser interativa, a exibição do filme deixa de ser playback (reprodução) e se torna rendering (interpretação)"125. 
estou sentado em um banco, em um estúdio, diante do fundo verde chroma key. barba, cabelos, bigodes, sombrancelhas, são raspados por uma mão invisível.

filma-se toda ação com duas câmeras, uma mais aberta, outra mais próxima.

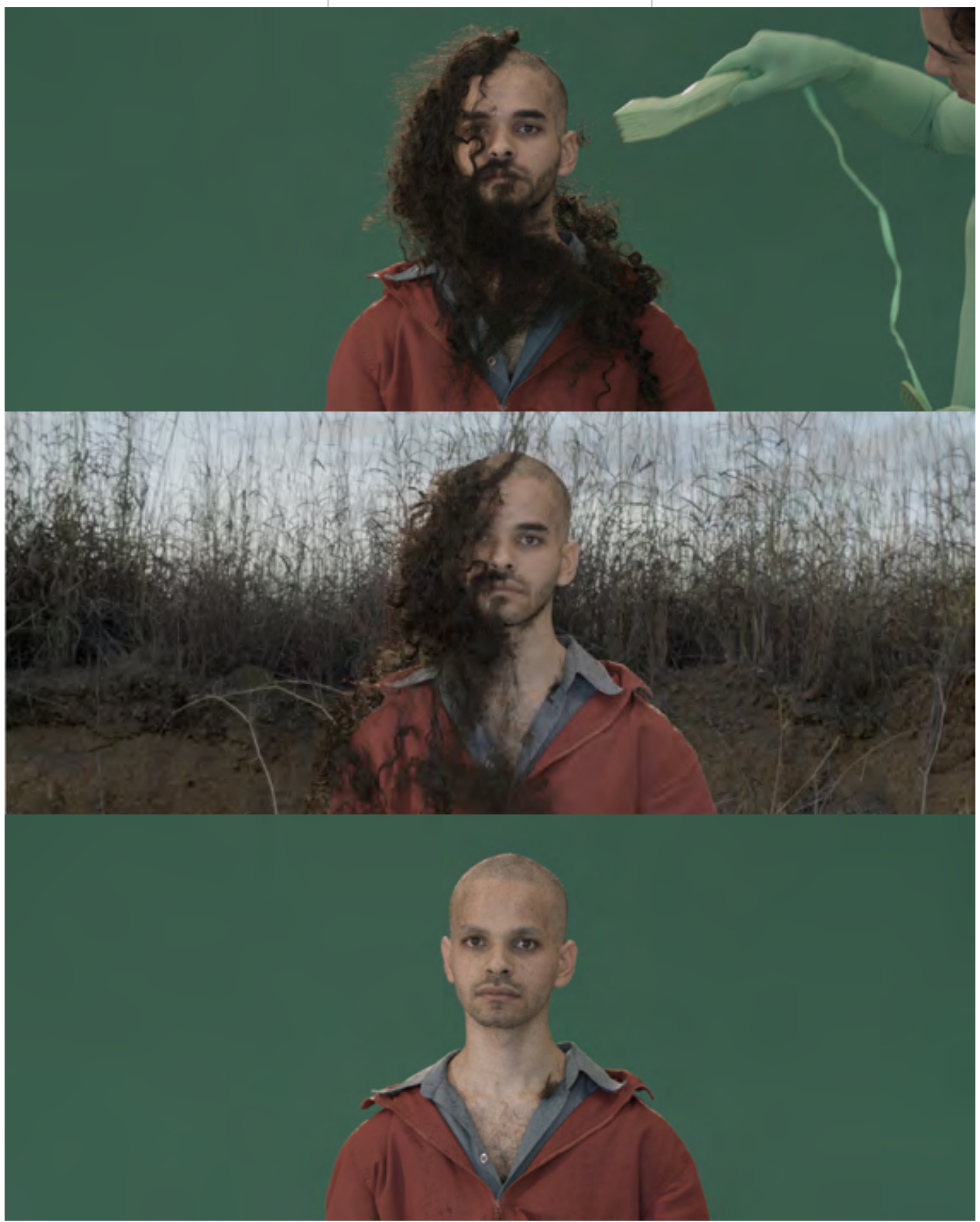

Imagens de Nunca vi meu pai sem bigode, Maurício Chades, 2016 
A captura feita por câmeras de vídeo e as possíveis remixagens e colagens permitem aos artistas pensar a recriação do mundo. $\mathrm{O}$ ato puramente cinemático das imagens e dos sons já inclui na cena o movimento dos corpos e das paisagens, mas as contribuições das interferências digitais "escrevem as imagens em linhas e ampliam o poder de metamorfosear" ${ }^{126}$ eletronicamente. O corpo, a natureza e os sistemas artificiais estão, finalmente, em evidente simbiose tecnológico/artificial/natural "interfaceado ao físico/real e virtual/digital"127. O efeito de incrustração interessa, sobretudo, por possibilitar que corpo e cenário provenham de fontes distintas, que se misturam em uma imagem dita final, mas podem separar-se novamente, para serem recombinados em outra truncagem, em um eterno efeito de passagem. Corpo e paisagem "funcionariam assim como duas realidades independentes agenciadas no mesmo quadro" ${ }^{128}$.

Durante a década de 1970, o vídeonarciso surge como um grande gênero. "O vídeo modernista não conhece a noção de ator, na imagem há apenas corpos de autores"129, quando o artista se põe em cena, muitas vezes até a fragmentação. A recorrência de mesclas de imagens, sobreimpressões, jogos de janelas, incrustrações, o uso do chroma key, denotam uma empolgação dos artistas com as possibilidades oferecidas pelas novas tecnologias, mas também colocam o corpo como um agenciador de fundos, composições, cenários, espaços, uma maneira de se apreender o que está sobreposto, dobrado, nas várias camadas: imagens possíveis. Para Dubois, a sobreimpressão permite uma multiplicação da visão ${ }^{130}$, quando se produzem transparências relativas: "cada imagem sobreposta é como uma superfície translúcida através da qual podemos perceber outra imagem"131; ou quando se produzem espessuras estratificadas, em que as camadas sucessivas funcionam como um folheado de imagens e o quadro é uma superfície de criação no computador.

Para Michael Rush, boa parte dos primeiros trabalhos em videoarte podem ser vistos como a gravação de uma performance, "ou o que passou a ser denominado de ações performáticas"132. A filmadora tornou-se uma parceira de diversos artistas atraídos pelos meios de comunicação de massa eletrônicos, registrando ações íntimas, quase sempre ritualísticas. Para a imagem filmada, o espaço parece se definir por acordo

126 DOMINGUES, 2002, p. 71.

$127 \mathrm{Id}, \mathrm{Ib}$.

128 DUBOIS, 2011, p. 194.

129 Id, p. 166.

130 Id, p. 78.

$131 \mathrm{Id}, \mathrm{Ib}$.

132 RUSH, 2006, p. 87. 
entre lente, iluminação e todos os elementos colocados diante da câmera. Com maior campo focal, é possível, por exemplo, ver melhor o que está distante e, se o horizonte é limpo, livre de obstáculos, podemos pensar mais claramente os diversos planos dobrados no quadro cinematográfico, microcosmos organizados hierarquicamente. Sabemos que a câmera poderia se deslocar alguns metros e priorizar aquela ação que, daqui, é coadjuvante e parece mero preenchimento. Artistas como Ana Mendieta e Peter Campus pensam o quadro enquanto superfície onde se pode evocar várias camadas ao mesmo tempo, em que elementos podem ser colocados lado a lado, sobrepostos, em um efeito de frontalização da profundidade de campo característica da imagem cinemática.

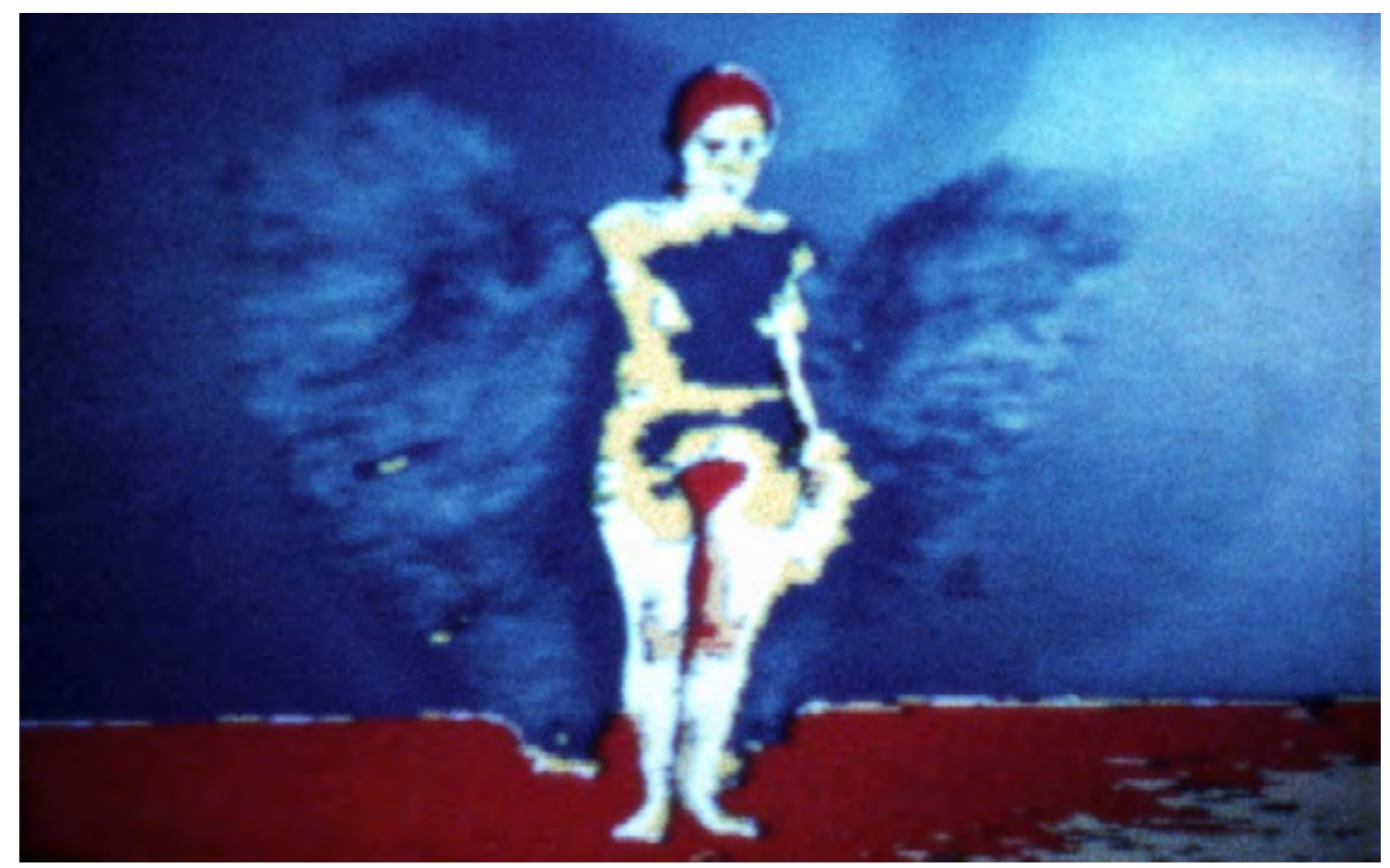

Butterfly, Ana Mendieta, 1975

Ana Mendieta é conhecida por seus trabalhos em que se torna um "corpo de barro", explorando sua identidade como emigrante em fotografias, vídeos e esculturas. Exilada de Cuba aos 12 anos e enviada a um orfanato em Iwoa, Mendieta pensa os deslocamentos, revelando-se em várias paisagens ao mesmo tempo em que revela os espaços através do corpo. Entre 1973 e 1977, a artista realiza uma série de trabalhos em que se coloca nesses lugares como uma silhueta preenchida de rochas, flores, sangue, galhos, para invocar a "mágica, conhecimento e poder da arte primitiva, para expressar o imediatismo da vida e da eternidade na natureza"133, em suas próprias palavras. As mixagens em Butterfly e a consequente imagem distorcida não deixam de produzir 
profundidade, mas uma profundidade, por assim dizer, de superfícies, fundadas na estratificação da imagem em camadas imperceptíveis, fundidas entre si. A dialética do que está na frente (por exemplo, o corpo) e do que está atrás (cenário), o artifício mais comum de construção e composição da imagem, se perdem em um corpo e espaço fundidos. A reversibilidade da incrustração corpo/paisagem nos coloca a dinâmica de sob/sobre, superfície/fundo. Sendo os elementos deslocáveis na profundidade, o esgotamento desse intercâmbio pode ser explorado até a vertigem e a espessura da imagem passa a ser um espaço em que o que está fora e o que está dentro se confundem.

Dessa forma, paisagem e quadro não estariam necessariamente condenados com as possibilidades tecnológicas que, na verdade, ajudam a evidenciar como se produz o falso realismo que poderia ser praticado, não fosse a escolha pelo caminho inverso. "Desse modo, a tecnologia põe a paisagem a salvo de um retorno a uma natureza da qual ela, a paisagem, seria o equivalente exato"134. Para Cauquelin, o fato de em alguns filmes serem necessárias muitas tarefas (captação de imagens pela câmera, processamento em computador e digitalização, montagem, colagem de diferentes técnicas) revela o trabalho que, sem saber, fazemos quando "vemos" uma paisagem.

O corpo filmado é imagem e apenas imagem, não se trata mais da representação de um corpo. No vídeo, o corpo pode ser furado, despedaçado e queimado como imagem: "ele jamais sangra, pois é um corpo-superfície, sem órgãos"135. Ao mesmo tempo em que é a imagem que se apresenta orgânica como um corpo, figura reversível, mas plena em eterno lugar de passagem. Para Dubois, esse tipo de imagem tem "espessura", quando o princípio dos cortes, próprio da organização da montagem, perde lugar ou se desloca nas mesclas de imagens. Insto é, a regra da sucessividade, o "plano a plano", dá lugar ao acúmulo vertical das imagens. As imagens-corpo são montadas umas sobre as outras (sobreimpressão), umas ao lado das outras (janela), umas nas outras (incrustração), sempre no interior do quadro: “O contra-campo deste plano? Ele já está ali, incrustado, ou numa janela. O close que detalha? Ele já está ali, em medalhão, ou em pano de fundo"136. 


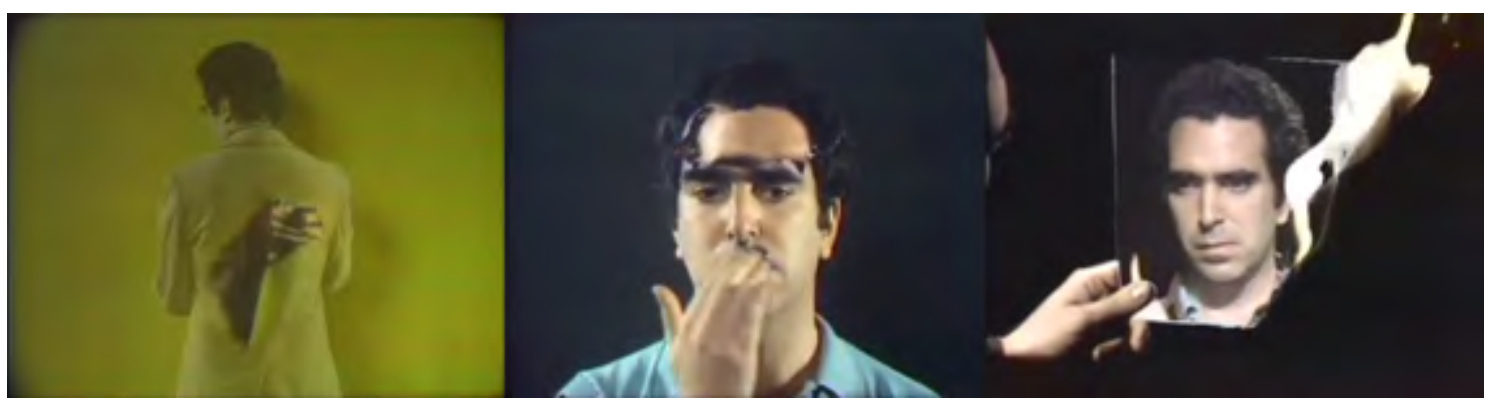

Three Transitions, Peter Campus, 1973

Na Série de vídeos Three Transitions, Peter Campus ataca a si mesmo criando com imagem filmada e imagem projetada um circuito possível para sua auto-destruição. No primeiro vídeo, ao cortar o fundo de papel com uma faca, o artista revela-se para a câmera preparada logo alí, apontada para o buraco que se abre. A imagem capturada pela câmera por detrás do fundo se projeta nas costas do autor e o esfaqueia. No segundo vídeo, o artista pinta a face com tinta, cuja cor é substituída digitalmente pelo próprio rosto, no que caracteriza a técnica chroma key. No terceiro vídeo da série, Campus utiliza o chroma key novamente, agora para incrustar seu rosto em uma superfície de papel e queimá-lo, para talvez livrar-se do fascínio pela auto-imagem do Narciso apaixonado por si mesmo.

"Fantasmagoria" e "aparência" são palavras que tem origem na mesma raiz grega. À semelhança dos trabalhos expostos, Butterfly e Tree Transition, Nunca vi meu pai sem bigode talvez trate disso em última instância: sobre a aparição/aparência do corpo e do espaço. As imagens não se organizam mais uma depois da outra, cada uma com sua função, dentro de um organismo. São imagens vivas, mas sem funções especiais. Imagens não adestradas, são improdutivas, mas intensivas. Não são instrumentos, mas conjuntos de sensações. 


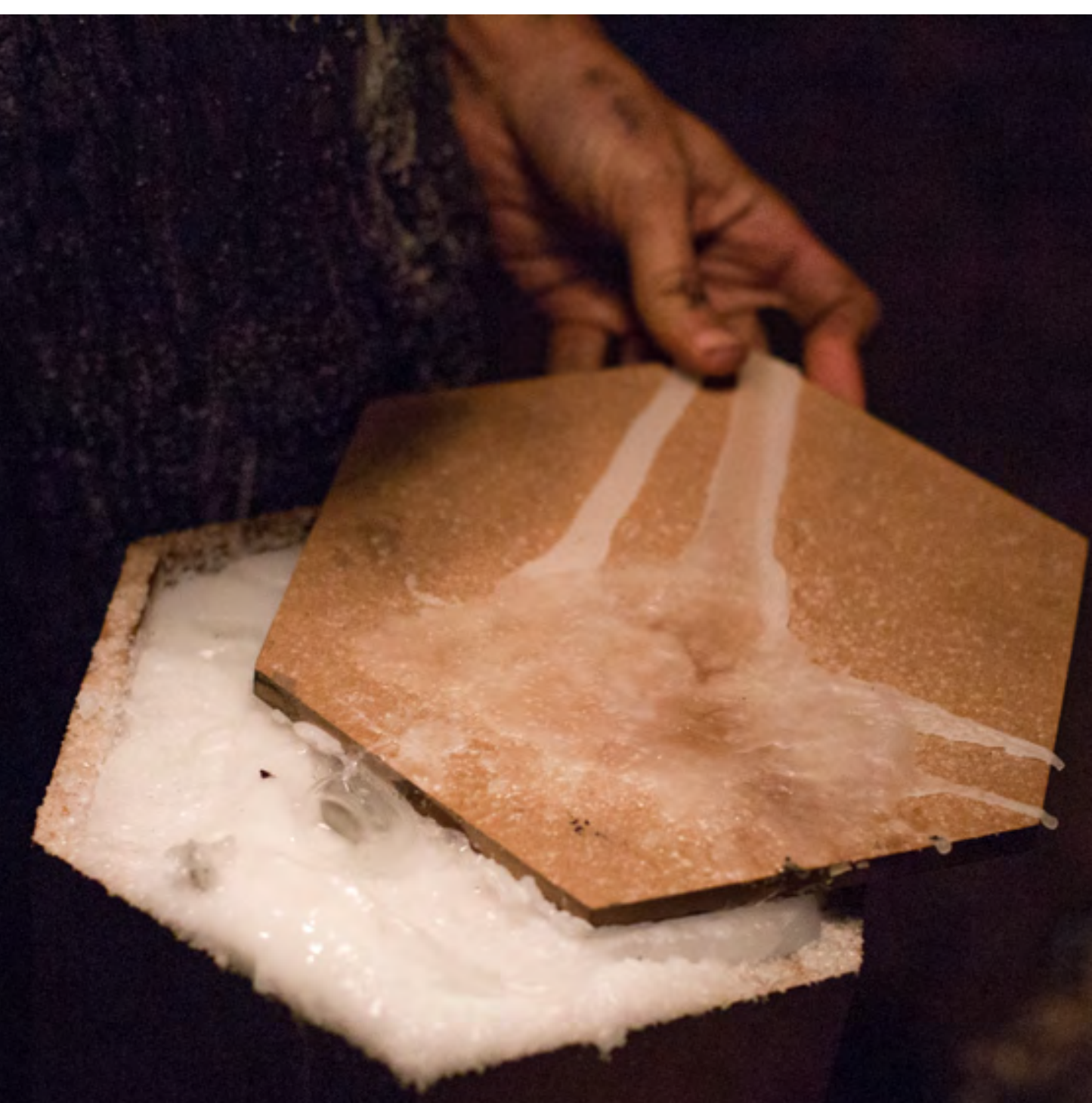

ENSAIO 6: CORPO, CONTINENTE ${ }^{137}$

vídeo: https://youtu.be/TVaaCW5yC_I

137 Ensaio livremente inspirado em textos de O que vemos, O que nos olha, Georges Didi-Huberman e Ser e Tempo, Martin Heidegger. Me reservei de fazer haspas ao longo do texto para não interromper um fluxo entre as frases dos autores e as minhas. 


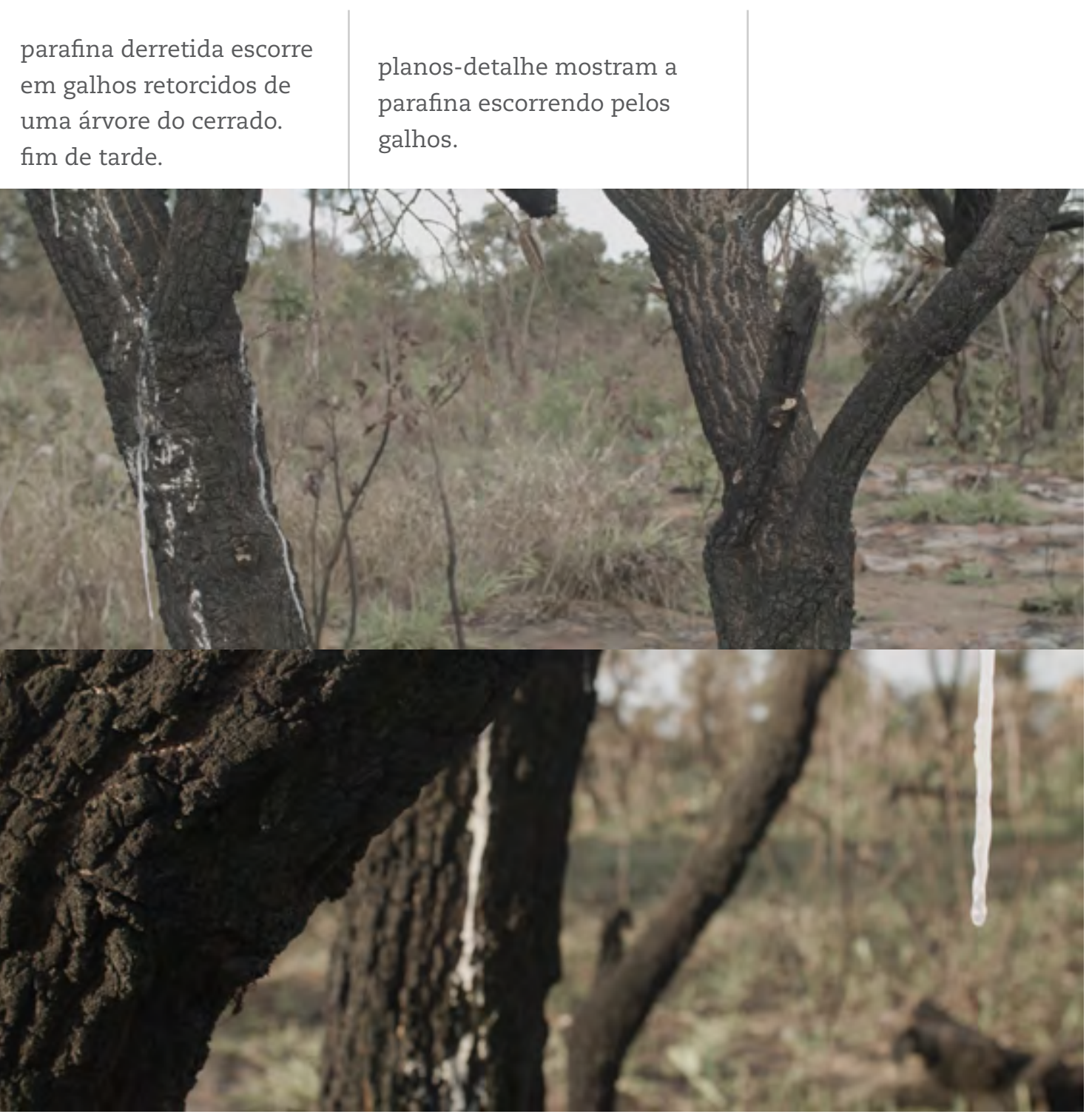

Imagens de Corpo, Continente, Maurício Chades, 2016

O caracol modela as escadas de sua casa com o próprio movimento de colocar-se para dentro e para fora. As escadas da casa, a casa, confundem-se com o próprio caracol, que carrega a casa para todos os seus destinos. A casa não é um lugar para voltar depois de uma jornada pelo mundo, mas algo que pesa, confunde-se com o peso do corpo, algo que limita o mundo às trajetórias ou mais curtas ou mais lentas. Quando se modela a casa com o corpo, quão perto se está de retardar o deslocamento a nada, a condicionar-se à imobilidade, à prisão?

Não se sentir em casa parece ser um fenômeno primordial de quem está aí. 


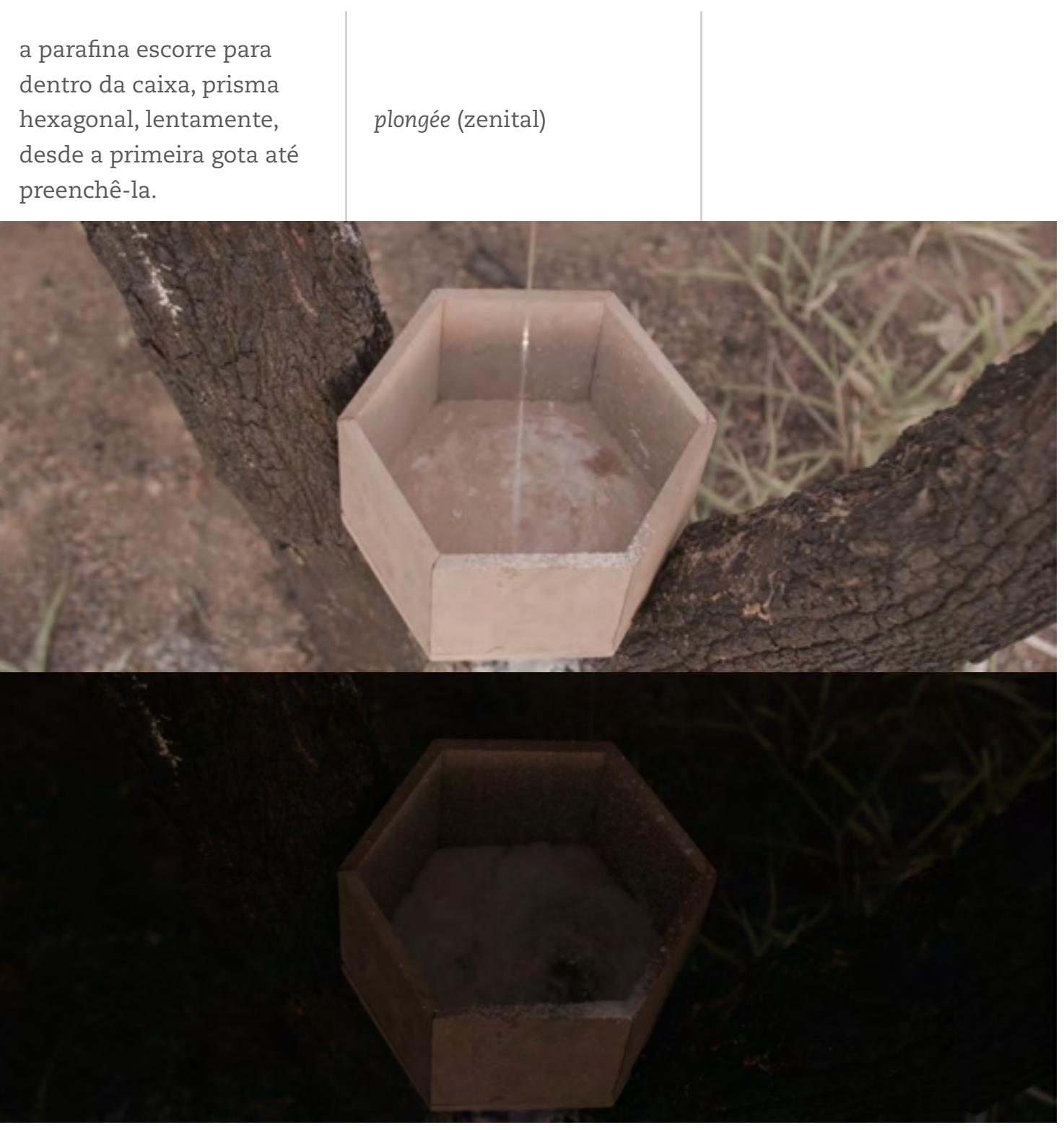

Imagens de Corpo, Continente, Maurício Chades, 2016

O que preenche o prisma, a concha, a casa, é semelhante a nós, de modo que denegamos o cheio, o morto, que é a própria angústia. Mas aí denegamos também o vazio, notadamente demarcado pela simplicidade da forma geométrica. O que é côncavo se insinua, oco, vazio de substância, mas disponível para recebê-la.

Tudo o que se mostra é fenômeno. No túmulo, o que se manifesta anuncia o que se vela. O espaço é o continente, e o vazio às vezes coloca a dimensão da angústia como a real substância, modelada às formas do túmulo, escapa à tampa, mas não se revela à luz do sol. A sensação é de ameaça, mas o ameaçador não se encontra em lugar algum. Não se sabe o que é aquilo com que se angustia. 
O ser-em, essencialmente espacial, abre-se para o mundo e o ameaçador vem de todas as direções, sempre presente, embora em lugar algum. Uma estranheza que persegue e ameça, que faz a angústia brotar nos momentos inoportunos, sem aviso prévio, dispondo-se sempre, de fato, à própria pre-sença com o ser-no-mundo, trantando-se de uma disposição fundamental.

Os corpos parecem querer escapar aos volumes que os suportam, que os incluem e encapsulam em tumbas. A angústia anuncia a condição de concha para todas as substâncias.
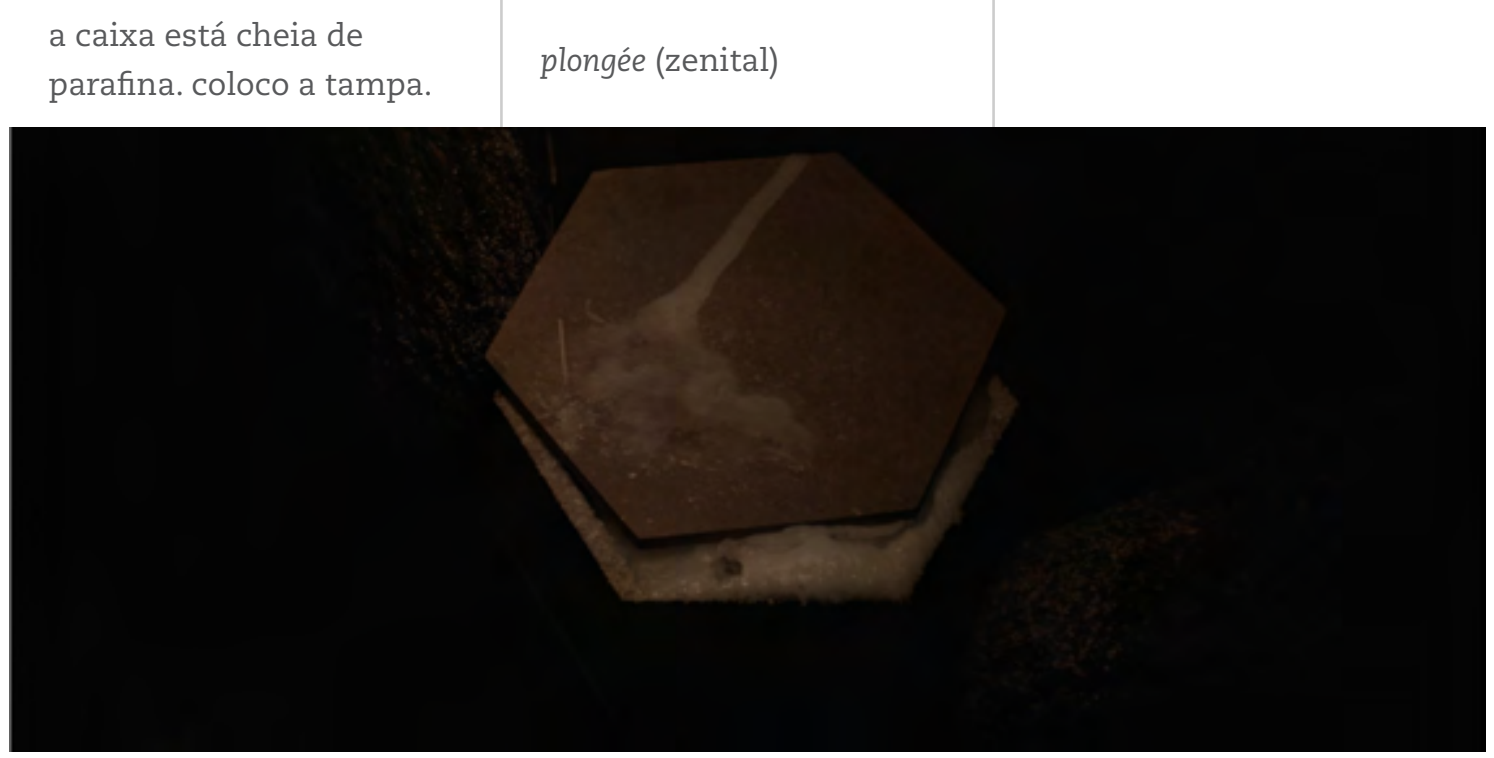
CONCLUSÕES 


\section{(PÓS)TEXTO I: \\ VIDEODISSERTAÇÃO E TEORIA}

Ao falar dos vídeos na dissertação, quando vídeos e textos tratam das mesmas questões, não quero tornar a dissertação uma reflexão sobre os vídeos. Também se pode classificar o texto entre pesquisa, dissertação escrita-filmada-performada, algo com um formato múltiplo. As práticas artísticas e a escrita configuram a pesquisa, desatando e atando nós. Textos a serem lidos e assistidos, mesmo que em alguns momentos a dissertação assuma um caráter mais formal, afim de contextualizar um lugar de fala, pontos de partida e provocações para os próximos pesquisadores que articularem essa rede de conhecimentos.

A arte escreve/inscreve sobre ela mesma.

O projeto mistura-se à minha vida e agora posso percebê-lo como simples. Assim, não separando vida de pesquisa, ou das práticas artísticas, a minha história é muito mais uma história sobre constituição, formulação e reformulação de problemas do que resoluções, "e a tomada de consciência dessa atividade é como a conquista da liberdade. (...) É a vida que se determina essencialmente no ato de contornar obstáculos, de colocar e resolver um problema"138. E para cada resolução, ou seja, para cada problema novo, chega-se alí com um arsenal de imagens, textos atualizados, vários dos quais já estavam ali, depositados ao longo da história. "Obras e textos se fortalecem mutuamente. Obtém-se, assim, uma teia apertada de referências cruzadas que serve como teoria"139, sendo, portanto, a teoria o resultado das remixagens das partes flutuantes em um espaço virtual, mas acessíveis para serem recombinadas em uma forma-pensamento. 
(PÓS)TEXTO II:

CAVERNA SEM PAREDES

Faço uso do espaço das conclusões para anunciar desejos futuros em relação a esse projeto que, parece-me, desdobra-se em trabalhos diversos. Assim, a parte da dissertação que se reserva a chamar "conclusões", na verdade, não encerra o trabalho, mas aponta para outras possibilidades, novos começos.

Nas salas tradicionais de cinema, "o filme se apresenta como único estímulo possível aos corpos amortecidos" ${ }^{140}$, que trata de uma disposição que teria relação direta com a arquitetura da sala, uma antiarquitetura. De forma semelhante, galerias de arte criaram interditos com o mundo de fora, lacrando janelas, quando o exterior não entra e as paredes são pintadas de branco. Segundo Brian O’Doherty, “a galeria é construída de acordo com preceitos tão rigorosos quanto os da construção de uma igreja medieval"141 e importa-se da religião um tratamento distanciado para a obra de arte, algo que, a modelo do filme na sala de cinema, não deveria ser interferido pela interação, pelo toque ou pela paisagem urbana (ou rural) que poderia ser revelada não fossem as paredes.

Principalmente desde o advento da televisão, o cinema investe esforços na implantação de uma série de tecnologias imersivas, como o som estéreo e a tela panorâmica (widescreen):

\footnotetext{
A sala de exibição estaria destinada a se tornar um lugar pelo qual os corpos trafegariam sem solavancos, do qual entrem e saiam sem qualquer impedimento, e onde permaneçam imóveis durante todo o tempo de projeção do filme - sem se cansarem, sem tocarem uns nos outros. Toda uma gama de pequenas tecnologias em favor da situação cinema começará a ser desenvolvida, entre as quais a cadeira de estádio, que permite visão perfeita da tela para toda a audiência ${ }^{142}$.
}

De forma que funda-se aí um modelo em que toda forma de consumo é desimpedida, desde o filme a pipoca, doces e refrigerante, quando os multiplexes, caracterizados sobretudo por várias salas de cinema organizadas em torno de um foyer, tornam-se um cercado completamente neutro, compatível com qualquer tipo de filme. Investe-se em uma qualidade de experiência bastante diferente da que marcava os movie palaces, por exemplo, "uma vez que não estará relacionada à opulência social e a uma série de luxos acessórios ao filme. Muito pelo contrário, ela se baseará na 
supressão dessas (e de outras) distrações"143.

Com a experiência cinematográfica refém de um mercado inerte, chegamos a um ponto em que o moviegoing se esgota e começam a despontar eventos que lembram os primeiros cinemas do início do século XX, mas com as devidas atualizações das marcas do nosso tempo e das novas tecnologias. VJs montam suas telas, ou apontam os projetores para alguma parede, em espaços públicos, e, acompanhados de música eletrônica, um público passante (ou pré-avisado) pode se formar ali, isentos de qualquer pretenção de inércia. Os lugares em que o VJing se insere promovem a dispersão cognitiva, uma vez que, a projeção de imagens é só um entre vários estímulos sensoriais. Inspirado nessa relação tão comum às festas de rua das cidades contemporâneas, proponho Pirâmide, Cinema como um protótipo de "sala" de cinema, uma alternativa utópica a um dispositivo rígido e reconhecível, pouco afeito às mudanças.

Em Pirâmide, Cinema os espectadores podem se deslocar, navegar, sofrer os solavancos dos corpos, imergir ou distrair-se, e o filme se contaminará do contexto, praça pública ou bosque. A estrutura, a modelo da sala do multiplex, também é compatível com qualquer filme: tem sistema de som estéreo, tela retangular e projetor HD, mas todo filme será modificado, seja pela colagem, remediação, da própria instalação no espaço, seja pelas possibilidade de se "tocar" o material no modul8 ou outro software de mixagem de imagens utilizado por VJs. Nesse sentido, não quero surpreender realizadores desavisados em um espaço dispersivo que se impõe, pelo contrário, quero que eles intensionem na projeção essa dispersão. A projeção não costuma figurar como uma dimensão criativa para o domínio do diretor do filme, portanto, "não é de se espantar que estratégias realmente alternativas de exibição, das quais a teoria do dispositivo não dá conta, sejam consideradas como formas artísticas completamente diferentes do cinema"144. Inicialmente pensada para receber as projeções dos vídeos realizados ao longo deste projeto, reitero que Pirâmide, Cinema pode sim ser vista como videoinstalação ou transcinema, mas a principal indagação aqui é propor a obra como um modelo de cinema sem paredes, uma alternativa ao modelo vigente, justamente por manifestar-se afeita a outros filmes, não sendo, portanto, um circuito fechado. 


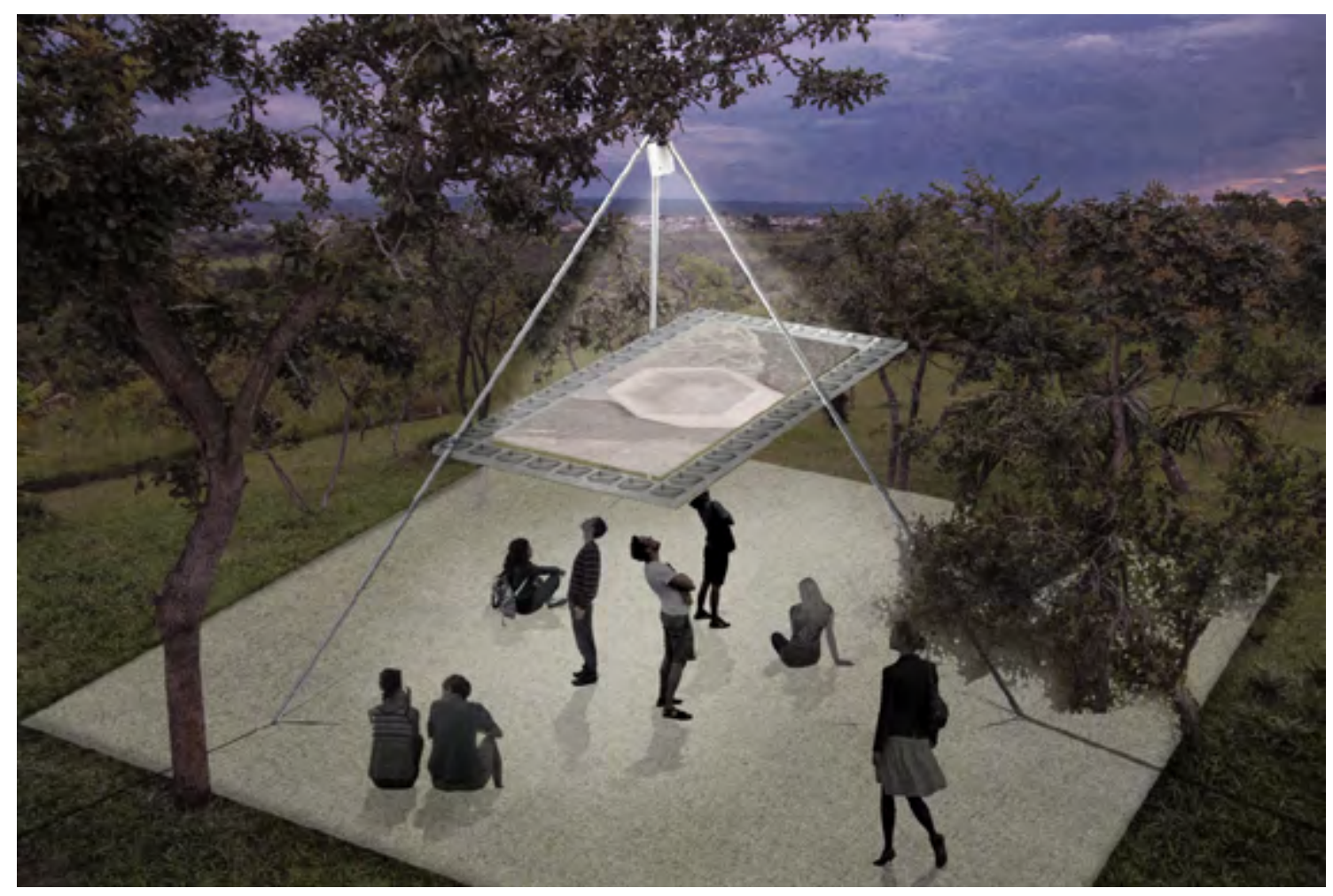

Pirâmide, Cinema, Maurício Chades, 2015. Croqui: Gabriela Bílá, 2015

No lugar da poltrona confortável, o chão e almofadas. no lugar do ar-condicionado, o ar poluído das ruas ou o ar puro da zona rural. Em vez de paredes escuras, o horizonte. Proponho Pirâmide, Cinema evidenciando a variedade inumerável de cinemas possíveis em relação ao "cinema, só". Se trata de propor uma arte nova, mas para metamorfosear algo que já está aí, em um dimensão mental própria de todos os dispositivos da imagem, da qual o cinema também faz parte. Pirâmide, Cinema é, na verdade, sobre práticas muito antigas, potenciais adormecidos. 
(PÓS)TEXTO III:

O VJ, OUTRA VEZ

Quando o espaço passa a existir, iluminado, público presente, máquinas e VJ à vista, "realidade e diegese acabam sorvendo um ao outro"145, uma reconfiguração em que imagens projetadas e espectadores se encontrando em estado virtual. NoTV Peter Greenaway Tulse Luper VJ World Tour, um dos desdobramentos de The Tulse Luper Suitcases, trata de uma série de mais de 30 apresentações de VJ em palácios, teatros modernos, casas de ópera em que o público é levado a se identificar não só com Luper, protagonista do filme vivo que se monta ao longo da performance, mas também com seu criador, que assume uma posição de maestro em frente às telas de projeção.

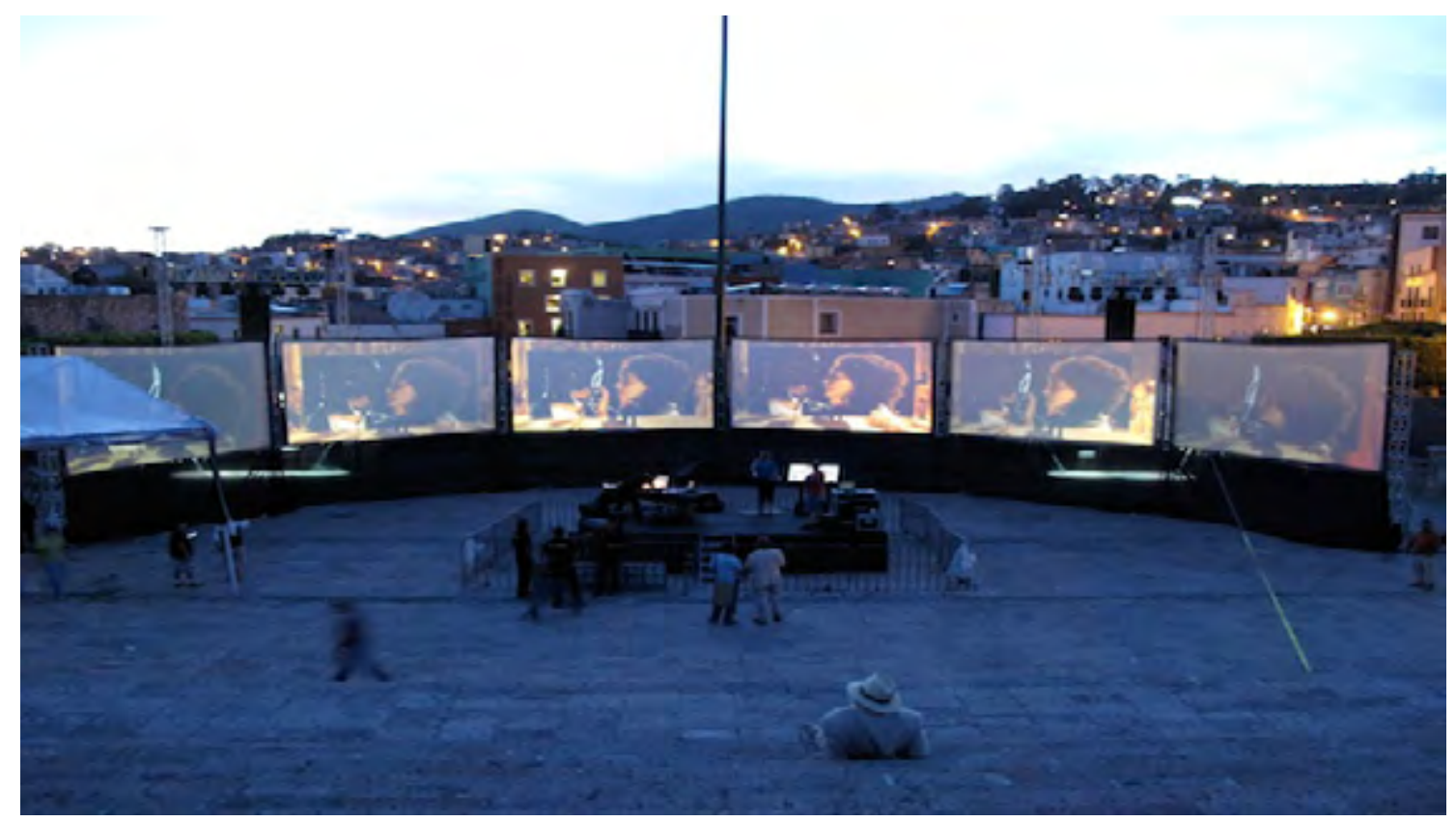

Passagem técnica de NoTV Peter Greenaway Tulse Luper VJ World Tour, 2010, em Guanajuato, México

A performance de Greenaway devolve ao filme a continuidade do processo criativo que costuma se encerrar na mesa de edição, quando o montador seleciona trechos de arquivos em um banco de dados, organiza de determinada maneira e finaliza aí as possibilidades de diversos outros filme que poderiam surgir do material bruto.

Ao trazer o realizador para o espaço de exibição, a Tulse Luper VJ Performance parece reunir produção, pós-produção e consumo no mesmo evento, encerrando a digitalização do circuito cinematográfico. Nesse sentido, ela parece representar o modo como as mídias digitais redefiniram a produção do filme ${ }^{146}$. 
Dessa forma, o ato de projetar, durante a performance de VJ, precede o registro do filme enquanto potência criativa. Para Godard ${ }^{147}$, projetar é o ato primeiro e primordialmente ontológico do cinema, quando o ato de registrar a imagem ja é um ato de projeção.

Para Deleuze ${ }^{148}$, o plano pode ser assimilado a proposições, a enunciados orais, podendo ser considerado como o menor enunciado narrativo. O loop, um primo próximo, ou uma versão indicial do plano, tratando-se de VJing, parece atualizar a função de proposição, de frase a ser lida e reescrita ao ser justaposta e relacionada, tornando-se um anglicismo recorrente no meio artístico que "expressa a repetição de pequenos trechos (de som, de imagem, de programação, de processos, dispositivos e gestos os mais variados), visando à criação de um todo cujo significado extrapole a soma de suas partes constituintes"149.

O loop parece ser uma boa forma de manter o filme inacabado, recombinável. Em Pirâmide, Urubu, proponho versões "montadas" para cada um dos vídeos, além da versão em curta-metragem que recombina o material dos 6 vídeos em um filme. Mas o próprio registro do tempo que se faz em várias das imagens, do movimento interno do quadro em ações duradouras e contínuas, como quando se preenche por completo uma caixa de madeira com parafina, gota a gota, no vídeo Corpo, Continente, percebo aí um movimento cíclico possível da imagem, de ir e vir, girar, ser invertida, receber as interferências que bem interessam aos VJs. Dessa forma, proponho aqui, no final da dissertação, uma nova abertura interativa ao projeto, uma proposta a quem quiser continuar esses filmes, remixando em festas ou outros contextos o Pirâmide, Urubu Biblioteca de Loops, um pacote de 20 loops disponíveis para download gratuito ${ }^{150}$.

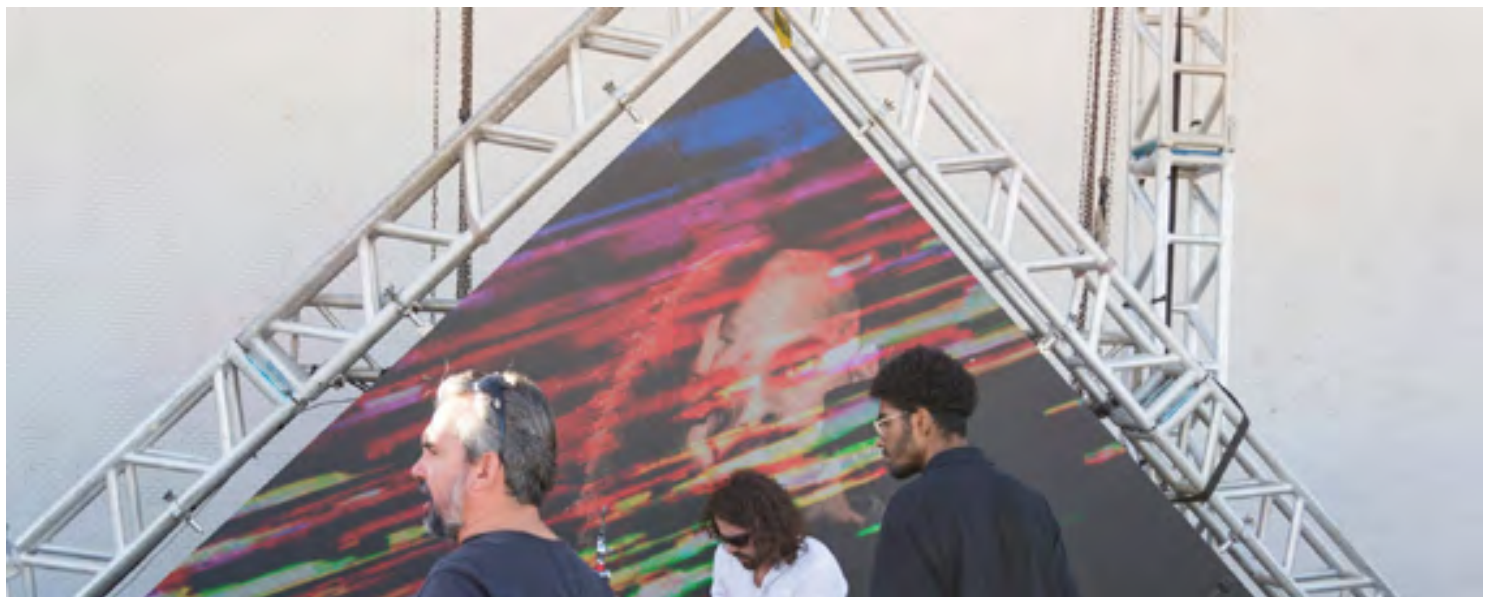


As novas tecnologias parecem nos apontar para o novo e para o incerto, em um primeiro momento, até que começam a descamar no próprio tempo substâncias suspensas, práticas e potenciais alí, sobrepostos, prontos para serem acessados ou, melhor, para serem reativados por um dispositivo catalisador. Como que por um gesto ritual realizado por um xamã, que pode nos reconectar com energias estratificadas e dispersas, a arte tecnológica nos remete mais uma vez à ideia de que o tempo é percebido e lido continuamente, em uma linha do tempo, mas esta é só uma das formas de sua expressão. Assim, "as tecnologias nos recolocam em formas de comunicação muito próximas das utilizadas nas sociedades primitivas, nos rituais tribais e religiosos com suas lógicas participativas e pensamento mágico"151. E é através do ritual que reside o desejo oculto de visitar o mundo espiritual, prolongando o mundo físico, ganhar forças e aumentar a capacidade de sentir e modificar a condição humana, a cultura.

Para Apichatpong Weerasethakul, "assistimos a filmes instintivamente, como uma terapia para a dor mental ou emocional” ${ }^{152}$. Dezenas de milhares de anos atrás, quando nossos ancestrais viviam em cavernas, eles frequentemente desenhavam em suas paredes, para mostrar como eram suas vidas. "Parece ser uma força desconhecida em nosso sangue"153. Ao pensarmos dessa forma, é possível dizer que os cinemas, tanto dentro quanto fora das lojas de departamento, são nossas cavernas modernas. 


\section{REFERÊNCIAS BIBLIOGRÁFICAS}

AZZI, Daniella e Francesca (org). Apichatpong Weerasethakul. São Paulo: Iluminuras, 2014.

BACHELARD, Gaston. A poética do Devaneio. São Paulo: Martins Editora, 2008.

A poética do Espaço. São Paulo: Martins Editora, 2008.

CAMPBELL, Joseph. O Herói de Mil Faces. São Paulo: Editora Pensamento, 2009.

O Poder do Mito. São Paulo: Palas Athena, 1990.

CAUQUELIN, Anne. A invenção da Paisagem. São Paulo: Martins Editora. 2007.

No Ângulo dos Mundos Possíveis. São Paulo: Martins Editora. 2011.

CRARY, Jonathan. Suspensões da percepção: atenção, espetáculo e cultura moderna. São Paulo:

Cosac Naify. 2013.

DELEUZE, Gilles. A imagem-tempo. Lisboa: Editora Assírio \& Alvim, 2009.

A imagem-movimento. Lisboa: Editora Assírio \& Alvim, 2009.

Bergsonismo. São Paulo: Editora 34, 2012.

DELEUZE, G e GUATTARI, F. O que é filosofia? São Paulo: Editora 34, 2010.

DIDI-HUBERMAN, Georges. O que vemos, O que nos olha. São Paulo: Editora 34, 2010.

DOMINGUES, Diana. Criação e Interatividade na Ciberarte. São Paulo: Experimento. 2002.

DUBOIS, Phillipe. Cinema, Vídeo, Godard. São Paulo: Cosacnaify, 2011.

FERRARI, Metthew P. Mysterious Objects of Knowledge: an Interpretation of Three Feature Films by Apichatpong Weerasethakul in Terms of the Ethnographic Paradigm. 2006. 86p. Tese ("Master of arts") - College of Fine Arts of Ohio University, EUA. Disponivel em: <http://rave.ohiolink.edu/ etdc/view?acc_num=ohiou1150466591> . Acessado em: abr. 2015.

FOLLAIN, Vera Lúcia. Narrativas Migrantes: Literatura, Roteiro e Cinema.

Rio de Janeiro: Editora PUC-Rio, 2010.

FUENMAYOR, Jesús. Memórias da Obsolência.

São Paulo: Museu da Imagem e do Som e Paço das Artes. 2014.

GREENAWAY, Peter. O cinema está morto, vida longa ao cinema? 2007. Publicado em Limite: Movimentação de Imagem e Muita Estranheza. Disponível em: <http://site.videobrasil.org.br/> Acessado em: julho. 2016.

HEIDEGGER, Martin. Ser e Tempo. Rio de Janeiro: Editora Vozes, 2005.

KWON, Miwon. Um Lugar Após o Outro. In: revista October 80. 1997. 
LIESES, Wolf. Arte digital - novos caminhos na arte. São Paulo: H. F. Ullman, 2010.

MACIEL, Katia (org). Cinema Sim: Narrativas e Projeções. São Paulo: Itaú Cultural, 2008.

A arte da Presença. 2006. Disponível em: <http://goo.gl/asToRW> Acessado em: julho. 2016.

MACHADO, Arlindo. A Arte do Vídeo. São Paulo: Editora Brasiliense, 1997.

Pré-cinemas \& Pós-cinemas. São Paulo: Papirus, 2011.

MARTIN, Marcel. A Linguagem Cinematográfica. São Paulo: Editora Brasiliense, 2003.

MASCARELLO, Fernando (org). História do cinema mundial. São Paulo: Papirus, 2006.

MENOTTI, Gabriel. Através da Sala Escura: espaços de exibição cinematográfica e Vjing.

São Paulo: Intermeios. 2012.

MERLEAU-PONTY, Maurice. Fenomenologia da Percepção. São Paulo: Martins Fontes. 2006.

NÓBREGA, Christus. Há_bit: tratado superficial de arquitetura cíbrida. 2011. 273p. Tese

(Doutorado em Arte) - Programa de Pós-Graduação em Arte - UnB, Brasília. Disponível em: <http:// repositorio.unb.br/handle/10482/10173> Acessado em: dez. 2015.

O’DOHERTY, Brian. No Interior do Cubo Branco. São Paulo: Martins Editora. 2002.

PARENTE, André. Cinemáticos. Rio de Janeiro: +2 Editora, 2013.

PERNIOLA, Mario. Pensando o Ritual: Sexualidade, Morte, Mundo. São Paulo: Studio Nobel, 2000.

RABELO, Fernando. Reconvexo Itinerante: vídeo-projeções mapeadas e interativas.

Brasília: Caixa Cultural. 2015.

SOUSA, E. L. A. Furos no futuro: utopia e cultura. In: Fernando Schüler; Marilia Barcellos. (Org.). Fronteiras: arte e pensamento na época do multiculturalismo. Porto Alegre: Editora Sulina, 2006.

RUSH, Michael. Novas Mídias na Arte Contemporânea. São Paulo: Martins Fontes. 2006.

STAM, Robert. Introdução à Teoria do Cinema. São Paulo: Papirus. 2003.

VELHO, Otávio Guilherme (org). O fenômeno urbano. Rio de Janeiro: Zahar Editores. 1973.

XAVIER, Ismail. O Discurso Cinematográfico: a opacidade e a transparência. São Paulo: Paz e

Terra, 2014. 


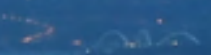

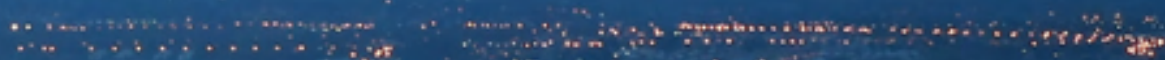

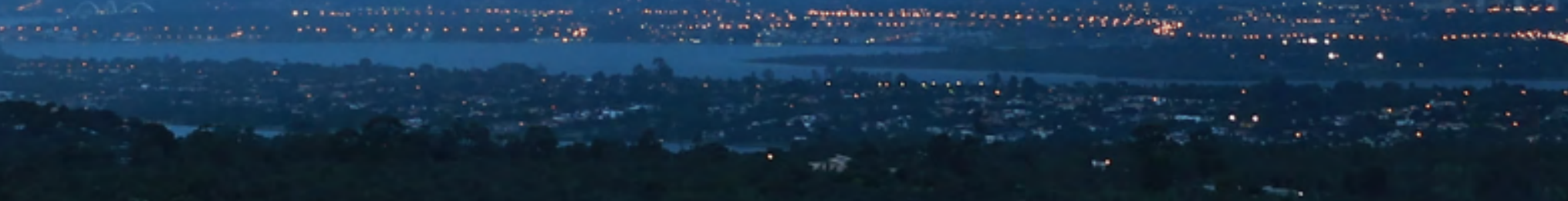

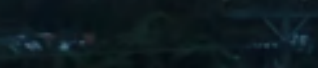
1. 